\title{
MASTER
}

\section{The Agricultural Sector Impacts of Making Ethanol from Grain}

Donald Hertzmark

Daryl Ray

Gregory Parvin
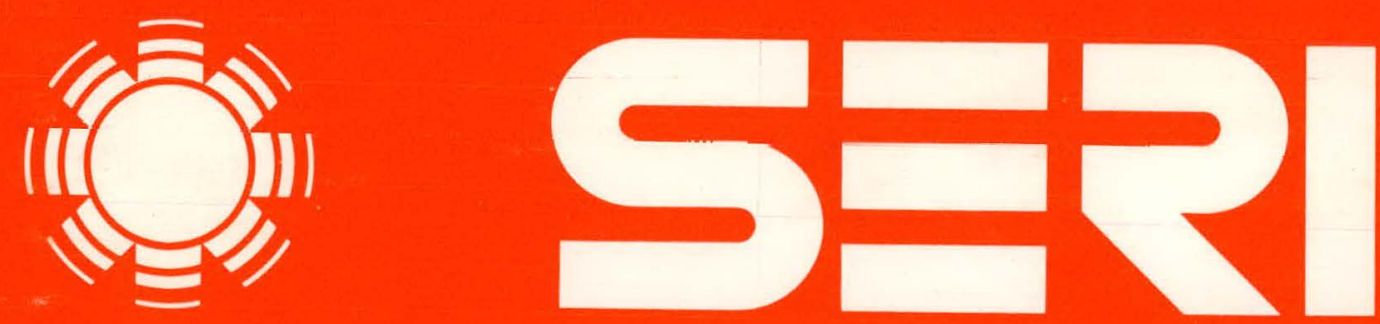

Solar Energy Research Institute

A Division of Midwest Research Institute

1617 Cole Boulevard

Golden, Colorado 80401

Operated for the

U.S. Department of Energy

under Contract No. EG-77-C-01-4042 


\section{DISCLAIMER}

This report was prepared as an account of work sponsored by an agency of the United States Government. Neither the United States Government nor any agency Thereof, nor any of their employees, makes any warranty, express or implied, or assumes any legal liability or responsibility for the accuracy, completeness, or usefulness of any information, apparatus, product, or process disclosed, or represents that its use would not infringe privately owned rights. Reference herein to any specific commercial product, process, or service by trade name, trademark, manufacturer, or otherwise does not necessarily constitute or imply its endorsement, recommendation, or favoring by the United States Government or any agency thereof. The views and opinions of authors expressed herein do not necessarily state or reflect those of the United States Government or any agency thereof. 


\section{DISCLAIMER}

Portions of this document may be illegible in electronic image products. Images are produced from the best available original document. 


\author{
Printed in the United States of America \\ Available from: \\ National Technical Information Service \\ U.S. Department of Commerce \\ 5285 Port Royal Road \\ Springfield, VA 22161 \\ Price: \\ Microfiche $\$ 3.00$ \\ Printed Copy $\$ 5.25$
}

\begin{abstract}
NOTICE
This report was prepared as an account of work sponsored by the United States Government. Neither the United States nor the United States Department of Energy, nor any of their employees, nor any of their contractors, subcontractors, or their employees, makes any warranty, express or implied, or assumes any legal liability or responsibility for the accuracy, completeness or usefulness of any information, apparatus, product or process disclosed, or represents that its use would not infringe privately owned rights.
\end{abstract}


SERI /TR-352-554

UC CATEGORIES: UC-58b; 61; 61a

THE AGRICULTURAL SECTOR

IMPACTS OF MAKING

ETHANOL FROM GRAIN

DONALD HERTZMARK

DARYL RAY

GREGORY PARVIN

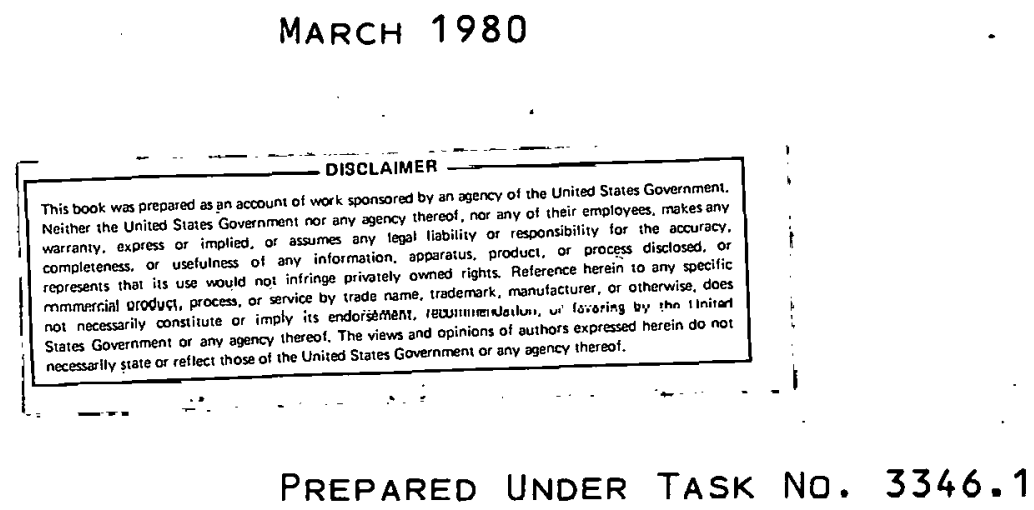

Solar Energy Research Institute

1536 Cole Boulevard

Golden, Colorádo 80401

A Division of Midwest Research Institute

Prepared for the

U.S. Department of Energy

Contract No. EG.77.C.01.4042 
THIS PAGE.

WAS INTENTIONALLY LEFT BLANK 


\section{PREF ACE}

This report is the final one of a series of three on the agricultural impacts of making ethanol from grain. The previous two reports provided preliminary assessm ents of the issues and a detailed analysis of joint-product use. The Analysis and Applications Division of the Solar Energy Research Institute (SERI) is also sponsoring work on the direct combustion of crop residues and the cultivation of specialized energy crops. The authors wish to thank Bert Mason, Wallace Tyner, and Richard Carlson for their helpful comments.

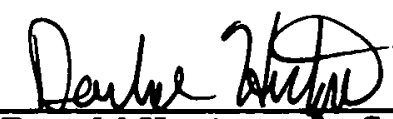

Donald Her tzmark, Senior Economist

Agriculture \& Transportation Group

Approved for:

SOLAR ENERGY RESEARCH INSTITUTE

Pextmasen

Bert Mason, Group Manager

Agricul ture \& Transportation Group

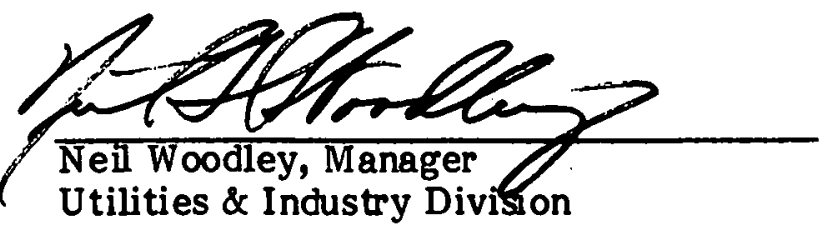


SERI* 


\section{TABLE OF CONTENTS}

Page

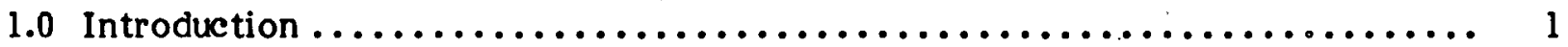

1.1 Statement of the Problem $\ldots \ldots \ldots \ldots \ldots \ldots \ldots \ldots \ldots \ldots \ldots \ldots \ldots \ldots \ldots \ldots$

1.2 Methodology $\ldots \ldots \ldots \ldots \ldots \ldots \ldots \ldots \ldots \ldots \ldots \ldots \ldots \ldots \ldots \ldots \ldots \ldots \ldots$

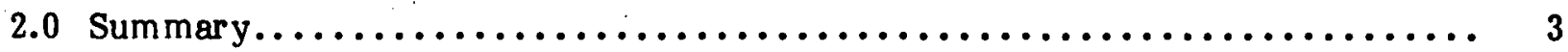

3.0 The POLYSIM Model................................ 9

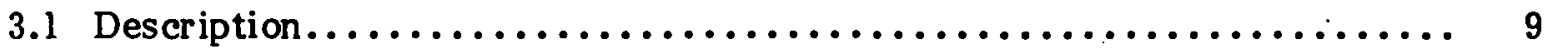

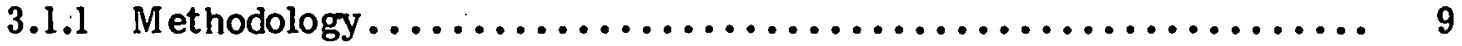

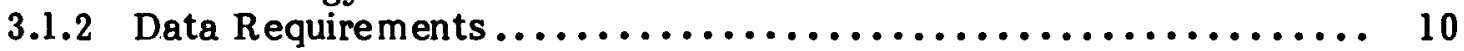

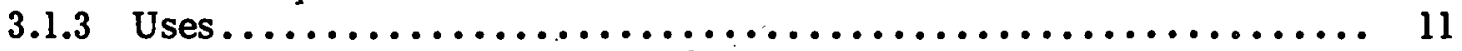

3.2 Modification of the POLYSIM Model for Ethanol Impact Analysis ...... 11

4.0 Analysis and Results ................................ 15

4.1 Feedstock and Joint-Product Economics ................... 15

4.1.1 The Biomass Refinery Concept ..................... 15

4.1 .2 Feedgrains Markets............................. 16

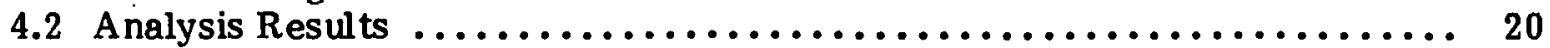

4.3 Stochastic Results................................. 39

5.0 Conclusions $\ldots \ldots \ldots \ldots \ldots \ldots \ldots \ldots \ldots \ldots \ldots \ldots \ldots \ldots \ldots \ldots \ldots \ldots \ldots \ldots \ldots$

5.1 Summary of Results $\ldots \ldots \ldots \ldots \ldots \ldots \ldots \ldots \ldots \ldots \ldots \ldots \ldots \ldots \ldots \ldots \ldots$

5.2 Limitations..................................... 58

6.0 References $\ldots \ldots \ldots \ldots \ldots \ldots \ldots \ldots \ldots \ldots \ldots \ldots \ldots \ldots \ldots \ldots \ldots \ldots \ldots \ldots \ldots$

Appendix A. Energy Analysis $\ldots \ldots \ldots \ldots \ldots \ldots \ldots \ldots \ldots \ldots \ldots \ldots \ldots \ldots \ldots \ldots$ 
SE기* 


\section{LIST OF TABLES}

Page

2-1 Price Eff ects of Alternative Ethanol Programs on Selected

Agricultural Sector Variables, $1979-1983 \ldots \ldots \ldots \ldots \ldots \ldots \ldots \ldots \ldots \ldots \ldots \ldots$. 7

2-2 . Ethanol Costs for Alternative Scenarios $\ldots \ldots \ldots \ldots \ldots \ldots \ldots \ldots \ldots \ldots \ldots \ldots$

4-1 Comparative Energy Use for Conventional and Biomass

Refinery Systems $\ldots \ldots \ldots \ldots \ldots \ldots \ldots \ldots \ldots \ldots \ldots \ldots \ldots \ldots \ldots \ldots \ldots \ldots \ldots \ldots$

4-2 Selected Price Elasticities Used in POLYSIM ................... 19

4-3 Growth of Selected Variables in POLYSIM $\ldots \ldots \ldots \ldots \ldots \ldots \ldots \ldots \ldots \ldots$

4-4 Growth of Selected Variables in POLYSIM Alcohol Scenarios ............ 24

4-5 Baseline and Simulation Data for 200 Million Gallons

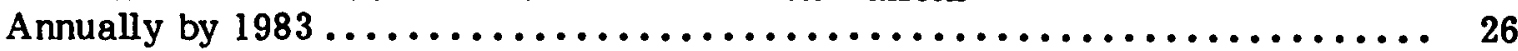

4-6 Baseline and Simulation Data for 350 Million Gallons

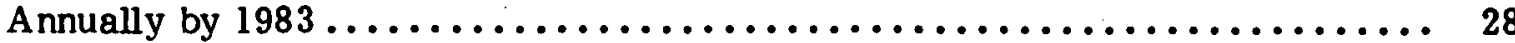

4-7 Baseline and Simulation Data for 500 Million Gallons

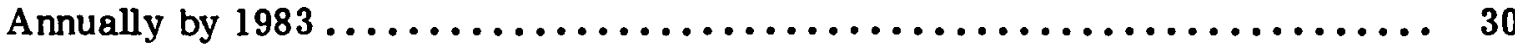

4-8 Baseline and Simulation Data for 750 Million Gallons

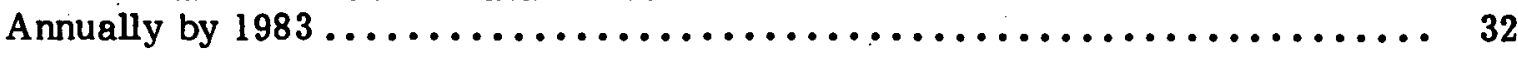

4-9 Baseline and Simulation Data for 1,000 Million Gallons

Annually by $1983 \ldots \ldots \ldots \ldots \ldots \ldots \ldots \ldots \ldots \ldots \ldots \ldots \ldots \ldots \ldots \ldots \ldots \ldots \ldots$

4-10 Baseline and Simulation Data for 3,000 Million Gallons

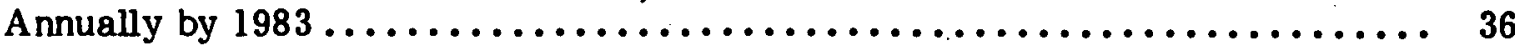

4-11 Stochastic Simulation Results for Selected Variables, 1979 and 1983

4-12 Extreme Values of Selected Variables in Stochastic Simulations

\section{LIST OP FIGURES}

$4-1 \quad$ Corn Gluten Meal Fed $\ldots \ldots \ldots \ldots \ldots \ldots \ldots \ldots \ldots \ldots \ldots \ldots \ldots \ldots \ldots \ldots \ldots \ldots . \ldots 42$

$4-2 \quad$ Dried Distillers' Grains Fed $\ldots \ldots \ldots \ldots \ldots \ldots \ldots \ldots \ldots \ldots \ldots \ldots \ldots \ldots \ldots$

4-3 Com Gluten Meal Price $\ldots \ldots \ldots \ldots \ldots \ldots \ldots \ldots \ldots \ldots \ldots \ldots \ldots \ldots \ldots \ldots$ 
LIST OF FIGURES (concluded)

Page

4-4 Dried Distillers' Grains Price $\ldots \ldots \ldots \ldots \ldots \ldots \ldots \ldots \ldots \ldots \ldots \ldots \ldots \ldots \ldots \ldots$

4-5 Soybean Meal Price................................ 46

$4-6$ Corn Price $\ldots \ldots \ldots \ldots \ldots \ldots \ldots \ldots \ldots \ldots \ldots \ldots \ldots \ldots \ldots \ldots \ldots \ldots \ldots \ldots \ldots$

4-7 Soybean Price $\ldots \ldots \ldots \ldots \ldots \ldots \ldots \ldots \ldots \ldots \ldots \ldots \ldots \ldots \ldots \ldots \ldots \ldots \ldots \ldots \ldots$

4-8 Büytean Meal Fed .................................... 49

4-9 Corn Exports $\ldots \ldots \ldots \ldots \ldots \ldots \ldots \ldots \ldots \ldots \ldots \ldots \ldots \ldots \ldots \ldots \ldots \ldots \ldots \ldots \ldots$

$4-10$ Soybean Meal Exports............................... 51

4-11 Soybean Harvested Acreage $\ldots \ldots \ldots \ldots \ldots \ldots \ldots \ldots \ldots \ldots \ldots \ldots \ldots \ldots \ldots \ldots \ldots$

4-12 Corn Harvested Acres $\ldots \ldots \ldots \ldots \ldots \ldots \ldots \ldots \ldots \ldots \ldots \ldots \ldots \ldots \ldots \ldots \ldots \ldots$

$4-13$ Soybean Cash Receipts............................... 54

4-14 Corn Cash Receipts $\ldots \ldots \ldots \ldots \ldots \ldots \ldots \ldots \ldots \ldots \ldots \ldots \ldots \ldots \ldots \ldots \ldots \ldots \ldots$ 
SBCTION 1.0

NTRODUCTION

\subsection{STATEMENT OP THE PROBLEM}

The availability and cost of liquid fuels is currently the premier issue of energy policy. In this report, the role of renewable alcohol fuels as extenders of gasoline supplies in direct substitution for petroleum is considered. In addition, the potential for indirect substitution of other biomass fuels and chemicals is discussed. Questions associated with the conversion of grains to alcohol include the effects of grain diversions to ethanol on supplies and prices, the net energy output of the conversion process, and the impacts of the joint products from ethanol conversion on feed markets. Also, the availability of land for energy crop production is briefly considered here. The work from which this report is derived represents ongoing research in the SERI biomass program.

Assuming that one of the more important goals of energy policy is a reduction in oil imports, then broader means of achieving that goal can be used than if the goal were simply to replace imported gasoline with domestic. This assumption shall serve as the statement of the problem.

One way to reduce petroleum imports is to use biomass fuels and chemicals more widely. This, however, may lead to other problems. First, the export of grain is the largest single contributor to the total value of U.S. exports. An energy policy leading to a net reduction in the value of agricultural exports would not alleviate the effect of reducing oil imports on the balance of trade since our ability to pay for oil would be reduced along with imports. A reduction in this country's export of grains would encourage higher domestic prices for feedgrains. This translates into higher prices for beef, other meats, and wheat. An alternative to food price inflation is the possibility that large amounts of available feed joint products (distillers' grains and gluten meal) would depress the price of soybeans. This could distress the farming community, since one of the sources of popular support for producing ethanol from grain is the positive effect that farmers believe ethanol will have on grain prices.

Clearly, it is impossible for ethanol to cause both inflation and depression of agricultural prices simultaneously. The real issue concerns the agricultural system's adaptation to changes in relative quantities of corn, soybeans, and other products. The process of adaptation has three distinct components: (1) the impact of these changes on the domestic feedgrain market; (2) the impact on the high protein market; and (3) the effect of grain alcohol on the balance of agricultural trade and on the balance of energy trade. In this last area, the net energy issue assumes critical importance.

\subsection{METHODOLOGT}

Several different quantitative and analytical techniques were used to arrive at the results presented here. Standard econom etric estimation techniques were used to establish the relationships of the ethanol feed joint products with the livestock markets and with 
other feeds. A detailed analysis of feeding ratios was presented in a previous report.* This information was put into the Agricultural Policy Simulator model (POLYSIM) to enhance the model's ability to handle large changes in the mix of products entering feed markets. The POLYSIM model is an aggregate simultaneous equation model of the agricultural sector of the U.S. economy. The driving force of the model is a supply and demand relationship for each of the crops included. This permits changes in the quantities and prices of the included crops to feed back on allocation of land and foreign sector demand. Government payments are also included in the model so that alternative types of subsidy programs can be considered. The major outputs of the model are farm income, crop prices, acreage of various crops, exports, total production, and retail meat prices.

In addition to modeling efforts, some of the standard apparatus of resource economics is used in the analysis of an optimal allocation of resources to ethanol production and to the highest value uses of that product.

*Hertzmark and Gould 1979. The Market for Ethanol Feed Joint Products. Golden, CO: Solar Energy Research Institute; Report No. RR-51-397. 


\section{SECTION 2.0}

\section{SUMMARY}

This summary presents the major economic issues involved in the conversion of grain to alcohol. Again, these issues are net energy, feedstock costs and economics, joint-product markets, balance-of-trade impacts in food and energy, and the availability of land resources to grow feedstocks. This approach differs significantly from other analyses of ethanol economics and costs on assumptions about technology and market responses. As a result, conclusions presented here differ from those of many other reports on ethanol.

Perhaps the most significant difference between this analysis and that of previous studies concerns the feasibility of ethanol as an automotive fuel. The average price of gasoline in this country is currently $\$ .65-.75$ at the refinery gate, exclusive of taxes, dealer markup, and transportation (Oil and Gas Journal, Dec. 10, 1979). It is not average gasoline, however, that is causing the havoc in our balance of paym ents. It is the marginal gasoline, both imported and domestic, that is the true competition for ethanol as a fuel or feedstock. At a price of $\$ 30 / \mathrm{bbl}$, the raw material cost alone of making unleaded gasoline from Libyan crude is about $\$ .71 / \mathrm{gal}$ * Adding tanker charges, refinery costs, and other charges, the refinery gate price of unleaded gasoline made from Libyan crude is $\$ 1.29 / g a l . * *$ That, however, is not the true margin of petroleum production. Oil from domestic stripper wells has reached $\$ 31 / \mathrm{bbl}$ while the spot price of crude on international markets fluctuates from $\$ 45-50 /$ bbl (Wall St. Journal, Oct. 16, 1979). At $\$ 45 / \mathrm{bbl}$, the refinery gate price of unleaded gasoline comes to $\$ 1.65 /$ gal. This implies a retail price in the neighborhood of $\$ 2.00 /$ gal. for marginal gasoline. At the current price for corn, and using conventional technology, the cost of production of ethanol is about $\$ 1.10 / \mathrm{gal}$. The wholesale price exceeds that by a wide margin because of the great demand for gasohol (OTA 1979). If the alternative to ethanol is marginal gasoline from stripper wells, syncrude, or imports, then ethanol is less expensive.

A nother point slighted in other work on ethanol is the question of substitution for petroleum via use in the petrochemical industry. Most petrochemical feedstocks come from the light fraction of the barrel. The current use of ethylene as a feedstock for synthetic ethanol production is a reversible reaction. That is, grain alcohol can be used for ethylene which in turn can be used in a multitude of chemical applications (Cinemlcal Week Jan. 31,1979 ). The idea that the only way to replace imported oil used for liquid fuels is to obtain a direct substitute is misleading and not conducive to formulating good policies. For example, the total quantity of gasoline that can be made from imports from Iran at the past year's level is about 4.5 billion gal. per year (108 million bbl). Total imports from Iran were 196 million bbl per year, so that the remainder, mostly heavier fractions, were used for heating oil. A solar technology such as ethanol that replaces the lighter fraction of the Iranian crude will permit the U.S. to replace the total imports from a particular country by replacing only the gasoline or chemical fraction. This is because of the relative ease of replacing the heavier fractions with conservation, coal, and active or passive solar energy systems.

*The value to be imputed to the gas-oil fraction is undoubtedly greater than $\$ .71$ $(\$ .71=\$ 30.00 \div 42)$, the average cost of each gallon in the barrel. Due to difficulties in determining the correct value, we have opted for average flgures.

**See Flaim (1978), updated to current prices. 
A nother area that has received a great deal of attention is the net energy production of ethanol relative to the fossil fuels used to produce the crop and to convert that crop to fuel and feed products. Using data derived from the whiskey distilling industry, some researchers have found that ethanol from grain is not a provider of net energy to the economy, for two reasons. First, the distillery is set up to use fuel oil (and not very efficiently). Second, almost all of the inputs to the growing of the crop itself are liquid or gaseous fossil fuels. Occasionally, the analysis is presented so that the energy content of the distillers' grain's joint product is counted along with the ethanol output. If this is done, a marginal net energy benefit may appear (U.S. DOE 1979). All of this discussion obscures several fundamental flaws in the use of the net energy argument as it has been framed with respect to alcohol fuels.

Since the same difficulty occurs in the analysis of markets for other products that are produced with ethanol, it is worth exploring the biomass refinery in some detail. A properly designed ethanol facility should be capable of turning out a variety of food, feed, and fuel products. These products include ethanol, gluten meal, cooking oil, distillers' grains, and (possibly) methane. Different grain feedstocks will yield different proportions of the various products. That is to say, by appropriate design of the processing plant and by proper purchasing of the feedstocks, the ethanol producer will have a variety of potential output mixes and associated costs. It is the job of the firm to allocate the fixed capital resources of the facility so that it can produce the various outputs at minimum cost. The analytics of this problem were presented in the appendix to an earlier paper (Hertzmark and Gould 1979). The results of that analysis show that the firm will achieve a maximum total return on the spectrum of products by achieving a minimum cost in the production of each one; i.e., by producing each product up to the point that the costs and the revenues are equal. This means that flexibility of the capital structure will be a paramount concern in a properly designed biomass refinery. The relevant economic question is identical to the relevant energy question: what is the most efficient means of producing all of the products that can come from this refinery? This question rearranges the usual net energy argument around the question of the final demands for potential outputs. If we ask about the most efficient means of producing all of the food, feed, and fuel products of the biomass refinery, then the answer will be far different than if we simply look at alcohol production and add in the energy value of the distillers' grains. The corn processing industry currently makes use of this type of fractionating of corn for sweetness, starch, and other products. The additional costs of a flexible plant are out weighed by its higher operating ef ficiencies.

Feed products and cooking oil have value because of properties-palatibility, usefulness for cooking, protein content-that are not denominated in energy units. It is germane to look at the energy requirements of producing these commodities by alternative means. But the Btu value of com oil is by no means a clue to its value. The energy requirements of growing corn are of little help in determining its value as a feed. The most energyintensive parts of the agronomic process come in the fertilizer requirements necessary for a high protein content in the grain. At the processing stage, there has not been a formal breakdown of the energy requirements of each of the processing steps for products other than alcohol. However, the one source that lists overall energy requirements shows that a well designed biomass refinery can be run almost entirely on waste heat from other processes within the plan or from the outside (Litterman et al. 1979; p. 27). This method of running the plant needs to be combined with two other factors. First, there is at least one distillation process that permits the coproduction of methane from the cellulose fraction of the corn grain. This quantity of methane is sufficient for about two-thirds of the process energy that is needed in vacuum distillation. Second, other biomass energy resources such as stover or residue may be used to fire boilers to cogenerate the various grades of energy needed in the refinery. 
The last point introduces what is perhaps the most telling objection to net energy analysis as it has been applied to ethanol production. Energy is available in various grades from mechanical work to space heating. Simply stating the energy content of an item in Btus is an insufficient measure of its energy value. If, for example, the biomass refinery is capable of using waste heat from a power plant or an oil refinery for its process steam, and if this steam assists in producing a portable fuel capable of performing mechanical work, then the energy balance question is not meaningful. It is not considered irrational to take three units of energy from coal and transform it to one unit of electricity. Similarly, obtaining a high-quality fuel at the cost of low-grade energy does not seem an unreasonable trade-off.

Fortunately, current technologies for the conversion of grain to ethanol and other products do not need the energy quality argument to be justified on an energy production basis. According to data from the Chemapec Company, the vacuum distillation process requires only about one-fifth the energy input of the older, beverage process. Improvements upon this latter process have lowered the energy requirements of the beverage process to about the same level as the vacuum distillation method (Chambers et al. 1979).

As noted above, indirect substitution for petroleum by biomass might be more efficient than concentrating all of the biomass resources on the production of substitutes for gasoline. An analogous situation appears in the consideration of the markets for the feedstocks for alcohol production and in the markets for the joint feed products. Two detailed analyses of the economic impacts of converting corn to alcohol were performed as part of the preparation of this report and its companion on the feed market effects of gluten meal and distillers' grains (Hertzmark and Gould 1979; the POLYSIM model was used in the preparation of this report). The model used for this paper was the POLYSIM model developed by Oklahom a State University. It is a simultaneous equation, supply and demand model of the agricultural sector of the U.S. economy. After performing some econometric estimations of the price relationships of the joint products gluten meal and distillers' grains with other high protein feeds and with corn, we modified the POLYSIM model to reflect a changed composition of high protein feeds and other nutrient sources. The results stress the role of indirect substitution in feed markets. The primary focus was on the change in mix of commodities that might be precipitated by a large fuel alcohol program. Several sets of relationships are crucial to this analysis. The first concorns thc corn -3oybean acreage respunse to relative price changes in the two crops. Com and soybeans are grown in rotation with one another in many parts of the country. Any tendency in the price of corn to rise because of the production of ethanol will be tempered by its increased value relative to soybeans. This leads to increased plantings of corn relative to soybeans. In addition, an increase in the price of corn and a fall in the price of soybeans will lead to higher exports of soybeans and lower exports of corn. A final mitigating factor will be the gluten and distillers' feed, which substitute for both com and soybeans. The preservative of the protein content of the com tends to shift the demand for digestible animal nutrients into forage crops. The implication of this indirect substitution is that several factors ure operating that will tend to dampen the price impacts on both corn and soybeans of high levels of ethanol production (see Table 2-1). These factors are: (1) the changes in values of the joint product feeds as corn or soybean prices change; (2) the versatility of corn in a number of different uses; (3) the relative ease and speed of changing from one crop to another; and (4) the relative ease of substituting feed and meal products for one another in both domestic and export markets.

Several anomalies appear in Table 2-1. The first is the extreme price deterioration of distillers' grains and gluten meal at ethanol production levels of more than l billion gal. yearly. One would expect export of these products to expand from current levels. 
Soybean prices rise in spite of a fall in meal prices because less acreage is devoted to soybeans. The fall in meal prices will be attenuated if distillers' grains and gluten meal maintain their values through exports. 
Table 2-1. PRICE EFPECTS OF ALTERNATIVE ETHANOL PROGRAMS ON SEI.RCTED AGRICULTURAL SECTOR VARIABLES, 1979-1983 ${ }^{\mathrm{a}}$

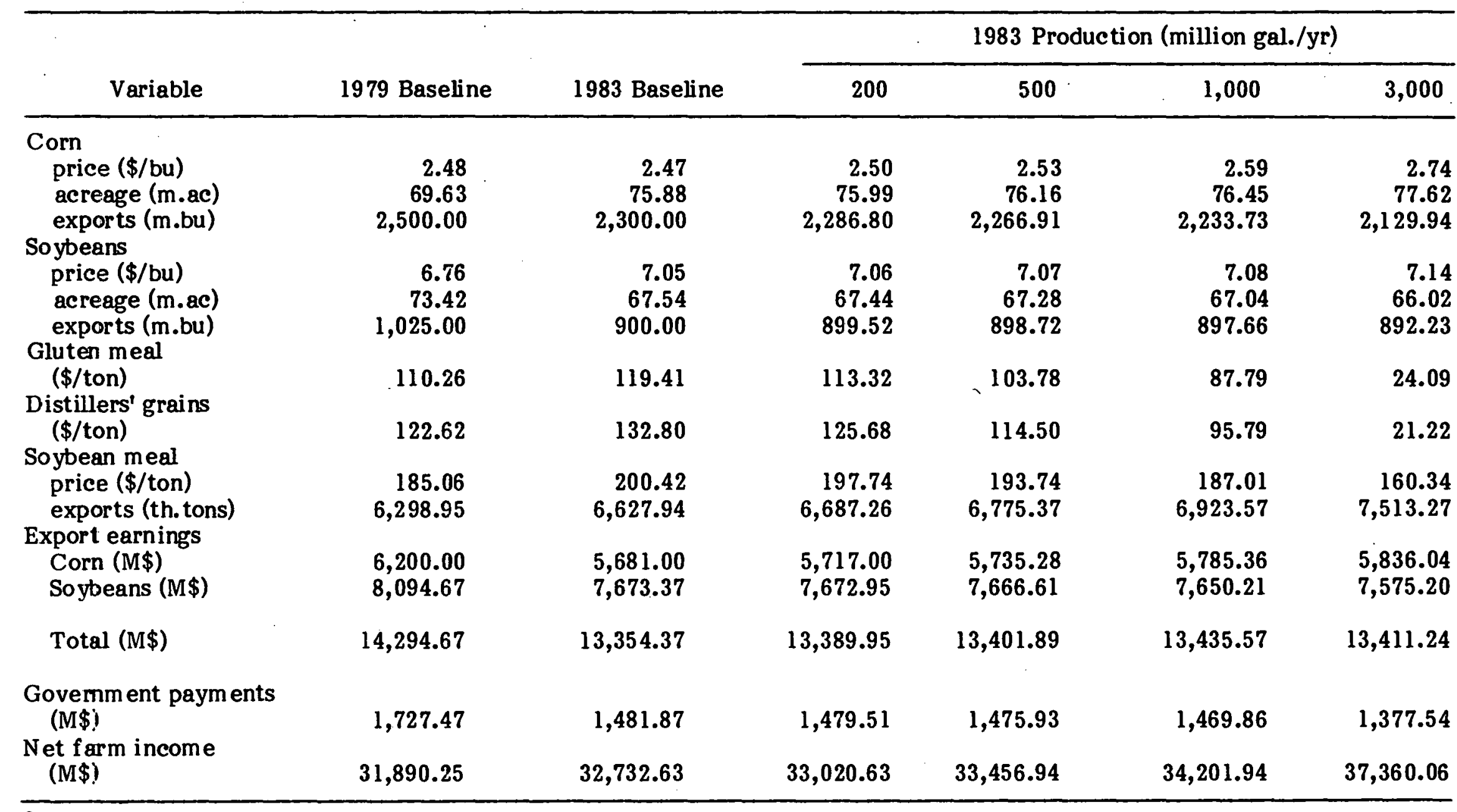

Source: POLYSIM 
Table 2-2. ETHANOL COSTS FOR ALTERNATIVE SCENARIOS (\$/gal.)

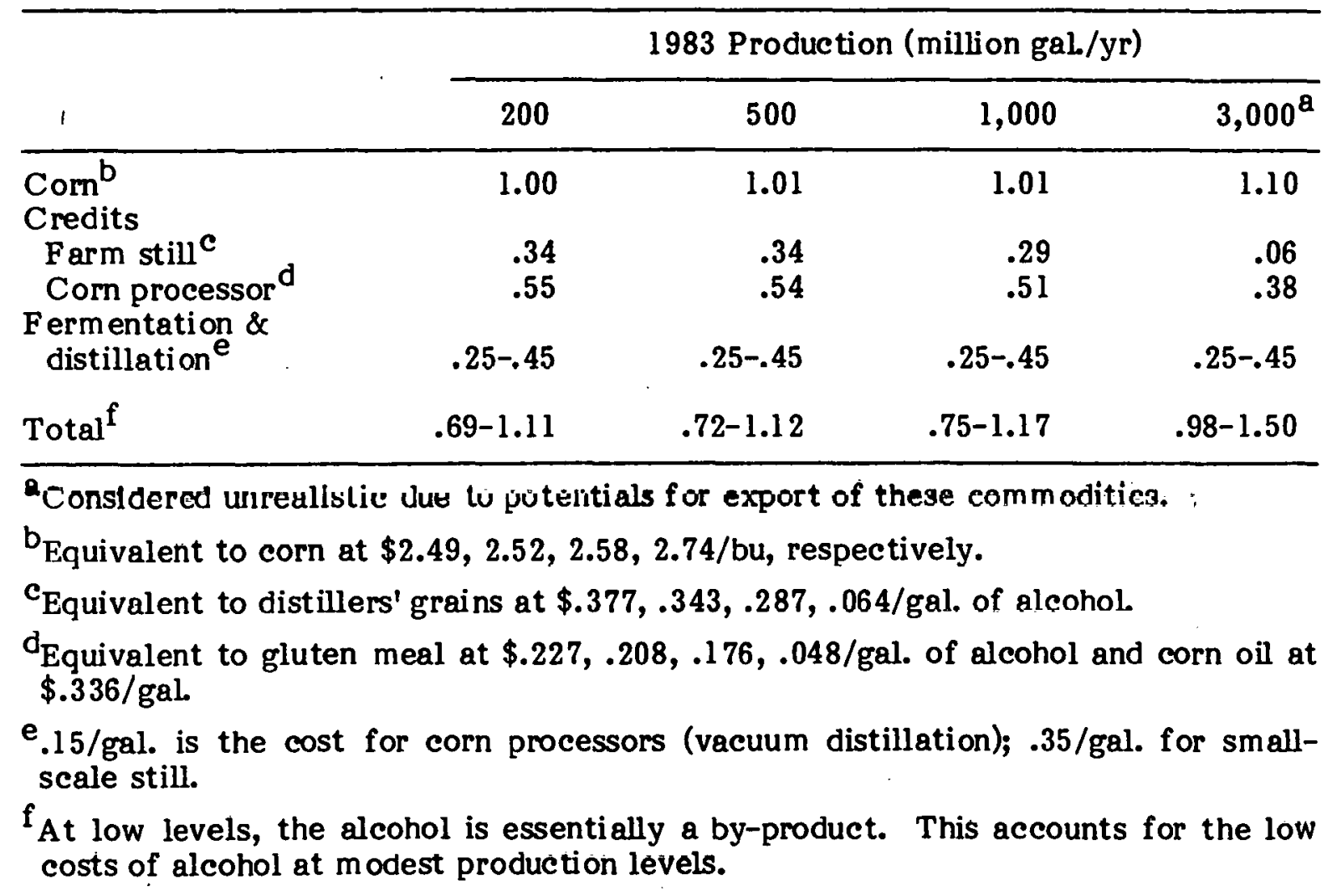




\section{SECTION 3.0}

\section{THE POLYSIM MODEL}

\subsection{DESCRIPTION}

The National Agricultural Policy Simulator (POLYSIM) was initially developed by Daryl Ray at Oklahoma State University in 1972. James Richardson, Gregory Parvin, and Ray have since expanded and refined the model through cooperative agreements with the Commodity Economics Division, Economics Research Service, U.S. Department of Agriculture. Operational at Oklahoma State and in Washington, D.C., at the USDA, POLYSIM has been used extensively at both locations since 1974. The focus in Washington has been on analysis of current economic issues while the emphasis at Oklahoma State has been on longer term research.

\subsubsection{Methodology}

POLYSIM is a perturbation model specifically designed for analyzing the effects of alternative U.S. agricultural policies over a four-to-five year time span. The perturbations are computed around a set of baseline projections of commodity supplies, prices, and use made by the USDA. The baseline projections (usually for five years into the future) are made by commodity specialists using formal models tempered with their own experienced judgments. The projections contain explicit assumptions concerning the rates of change in population, per capita incomes, consumer preferences, export demand, technology (including crop yields and livestock gains), and other supply and demand shifters. These projections also assume a specific set of government farm programs. POLYSIM simulates the effects of policy specifications that differ from those assumed in the baseline. The model focuses on the interaction of supply and demand responses that result from specified changes in commodity prices that resulted in turn from changes in policy conditions, while holding all other supply and demand shifters equal.

Commodity supply and demand elasticities represent an important part of POLYSIM. The driving forces in the model are the initial and subsequent changes in commodity prices resulting from changes in policy conditions. The magnitude of impact is determined by direct and cross supply-and-demand elasticities.

The crop and livestock commodities included in the model are:

\begin{tabular}{ll} 
Crops & \multicolumn{1}{c}{ Livestock } \\
\hline Feed grains & Cattle and calves \\
Wheat & Hogs \\
Soybeans & Sheep and lambs \\
Cotton & Broilers and farm chickens \\
& Turkeys \\
& Eggs \\
& Milk \\
\hline
\end{tabular}


F or each crop the model provides estimates of acreage, yield, production, variable production expenses, total supply, price, domestic demand, exports, carryover, cash receipts, and government paym ents. It also gives estimates of production, market price, and cash receipts for each of the seven livestock categories. Estimates for the various commodity variables are summed and added to exogenous data for commodities not included in the model to develop aggregate estimates of production expenses, governm ent payments, gross income, and realized net farm income.

After the model has been set up with user-supplied information on the farm program and policy variables to be analyzed, it begins simulating for the first year by calculating production and prices for each of the seven livestock categories. The production calculations are based on percentage differences bctween the previous year's baseline and simulated values for the price of the product, feed grain price, and prices of compoting products tinies the approppriate direot and cross supply elaslicities. The next step is to use the production information and exogenous import and export demands to compute the amounts of livestock products available for domestic consumption. The percentage change in livestock product availability is then computed. By using farm-level direct and cross price flexibilities, the current year's price for each of the livestock categories can be estimated.

The model then begins calculations for the four crops in the crop sector. As indicated earlier, the harvested acreage for each crop is determined as a deviation from the baseline acreage, based on the percentage deviations in last year's market prices for crops from their baseline projections times the appropriate direct and cross elasticities. Yield and per-acre variable production expenses are calculated with similar equations. The total production for each crop is calculated directly as the product of the yield and harvested acreage. Total variable production expenses equal per acre expenses times the harvested acreages.

Crop prices are calculated using price flexibilities and the perccntage clutige In crop supplies. Domestic and export demands depend upon the percentage change in prices and appropriate elasticities.

The final set of relationships in the model's simulation loop treat producer's costs, receipts, and income. Aggregate or national estimates are made for total recelpts, total government payments, consumer expenditures for food, realized gross income, crop expenses, protein, feed, roughage, and nonfeed costs for livestock, total variable costs, total production costs, and realized net farm income.

\subsubsection{Data Requirements}

Baseline values must be available for the variables in POLYSIM. As indicated, the USDA periodically projects these values five years ahead. The necessary crop and livestock supply and demand response parameters or elasticities must be assembled for use in the model. The elasticities currently used in the model were developed in three stages. Initially, a comprehensive literature review was made to gather past estimates of the required elasticities. Secondly, many of the elasticities were reestimated, using more recent data. Finally, to make the model more useful to the USDA, ERS commodity specialists reviewed the estimates, which had been categorized by commodity groups. The final revised estimates are used as default values in the model, but users can change any of the elasticities if they have better or more recent information. 


\subsubsection{Uses}

POLYSIM is tailored to analyze the agricultural, food cost, and government cost impacts of changes in agricultural policy instruments normally used in the United States. Anatyses can be made for changes in some government variables: target prices and resulting deficiency payments, loan rates, alternative CCC buy-and-sell criteria, allotments, voluntary or mandatory set-aside acreages, per acre payment schedules for voluntary set-aside, program participation rates, and acreage or production quotas.

The effect of yield and export levels different from those in the baseline conditions can also be investigated. The policy, yield, and export levels may be changed for any one crop or combination of the four crops included in the model (feed grains, wheat, soybeans, and cotton). The model traces the effects of these changes through interrelated crop sectors, seven livestock sectors, and finally to national aggregates such as realized net farm income. The computer cost of making a simulation run is less than $\$ 2.00$.

The validity of the model's results hinges on the accuracy of the baseline projections, or reference mode, used by POLYSIM, and on elasticity estimates. Both of these crucial information sets need critical evaluation and continual updating to ensure that POLYSIM draws on the best information available at each point in time.

As a descriptive model, POLYSIM cannot estimate optimum resource allocations for specific demand levels or productive capacity subject to resource constraints. Neither regional impacts nor estimates of price variations within a crop or calendar year are possible with the model. Although crop exports are endogenous, the world grain market is exogenous to the model. The model does not provide estimates of changes in farm size, farm numbers, or the organizational makeup of agriculture.

\subsection{MODIFICATIONS OF THE POLYSIM MODEL FOR ETHANOL IMPACT ANAL YSIS}

Two specific changes were made in the POLYSIM model to account for the diversion of some corn to ethanol. The purpose of the first of these changes was to account for the removal of a sufficient quantity of com to achieve the level of ethanol production given in each run. The second was a modification of the high protein feed sector. We assumed that each bushel of corn would make $2.5 \mathrm{gal}$. of ethanol, a conservative assumption since some other sources give the production coefficient as 2.6 or even 2.7 gal./bu (U.S. DOE 1979). Note that this is a differential of 5-10\% in the amount of corn required for a certain level of ethanol production and that such a production differential would result in a decrease of an equal proportion in the joint-product feeds. As a result, the impact figures given in subsequent sections of this paper may err more on the side of overstatem ent than of understatement.

In a previous paper, impacts were reported on animal feed markets of a large increase in the availability of two feed products-gluten meal and distillers' grains (DDG)-that are produced along with ethanol (see Hertzmark and Gould 1979). Similar analytical techniques were used to modify the POLYSIM model in order to enhance the degree of detail on the feed market impacts of joint products. Two different estimating equations were used to obtain the cross-elasticity and price flexibility coefficients of distillers' grains and gluten meal with each other and with such other feeds as corn, soybeans, and oilseed meals. Demand elasticities for the distillers' grains and gluten meal were obtained by using the following price flexibility equations: 


$$
\begin{aligned}
& \mathrm{P}_{\mathrm{DDG}}=41.3-1.25 \text { (total by-product feeds*) }+1.28 \mathrm{P}_{\text {gluten meal }} \\
& \mathrm{P}_{\text {gluten meal }}=-13.76-.0013 \text { (by-product feeds**) }+.749 \mathrm{P}_{\mathrm{DDG}}
\end{aligned}
$$

The arc elasticities that were obtained from the flexibility coefficients are given as:***

$$
\begin{aligned}
& \eta \text { (DDG, total by-products) }=-.37 \\
& \eta(\mathrm{DDG}, \text { gluten meal) }=.98 \\
& \eta \text { (gluten meal, by-products) }=-.0004 \\
& \eta \text { (gluten meal, DDG) }=.95
\end{aligned}
$$

It is interesting to note that the theoretical requirement that $\eta_{x y}=\eta_{y x}$ is met for DDG and gluten meal to a high approximation. The equations that were used in POLYSIM used flexibility coefficients instead of elasticities.

Modifications were eff ected through changes in the types of feeds that would be necessary to satisfy the protein demands in the livestock sector. A series of demand functions for high-protein feeds was used in this part of the model so that the quantity of the protein feeds demanded and the prices of these feeds, would be determined endogenously. The alternative would have been to have the demand imposed upon the model, simply parameterizing the prices of the feeds as would be done in a linear framework.

It was assumed that $\mathbf{5 0}$ percent of the alcohol produced would use the process that yields the distillers' grains joint-product. The other half of the alcohol would be produced using the wet milling process that yields gluten meal and cooking oil. As with the production coefficients for alcohol production, this analysis erred on the conservative side, since no export of the joint feed products was assumed. This has the effect of overstating the depressing effect of these feeds on the entire protein market as the high demand elasticities for exports of protein feeds would act as moderators of potential price declines of these products.

The supply equation for the distillers' grains and for the gluten meal were of the fixed coefficient type. As shown in a previous paper (Hertzmark and Gould), actual decision making by firms engaged in alcohol production could mimic closely the operation of the stylized multiproduct firm (presented in the appendix of that paper). Until there are more data on the actual production possibilities that face the alcohol producer, It may be preferable to use fixed coefficients.

One of the unique features of POLYSIM is its ability to perform stochastic analysis. In this feature of the model, such variables as export demand and domestic grain yield are

*Includes soybean meal.

**Excludes soybean meal.

***The cross elasticity of demand is given by the formula:

$$
\eta_{x, y}=\frac{\Delta q_{x} p_{y}}{\Delta p_{y} \dot{q}_{x}}
$$


allowed to vary randomly. From these variations, a frequency distribution for each of the endogenous variables in the model is obtained. Here, information was needed about the effects on the agricultural sector of such stochastic variation when there exists a steady and inflexible demand for corn by the fuel industry. The results of this exercise will be given along with the other model results in the following sections. 


\section{SEPI}




\section{SECTION 4.0}

\section{ANALYSIS AND RESULTS}

\subsection{FEEDSTOCK AND JONNT-PRODUCT ECONOMICS}

\subsubsection{The Biomass Refinery Concept}

The biomass refinery concept was used in the previous section in a discussion of the net energy issue. Two main assumptions are implied by this framework. The first is that various food, feed, and fuel outputs may be produced according to variable proportions rather than fixed proportions. The firms can respond to changes in input or output prices by altering the feedstocks and/or the products of the refinery. The usual fixed proportions model used in some other analyses (e.g., Litterman et al. 1979; U.S. DOE 1979; Tyne and Bottums 1979) is derived from the beverage industry where there is only one output that is of serious economic interest to the producing firm. It is easily shown that a highly specialized piece of capital equipment is more technically efficient than one which is flexible in terms of either inputs or outputs (Fuss and McFadden 1978; Chap. II. 4). The crucial economic questions are (1) whether receipts from a broader range of outputs can compensate for higher costs, and (2) whether higher capital costs will be matched by commensurate reductions in feedstock costs due to flexibility. In the present case, it turns out that continuous fermentation and vacuum distillation is actually less expensive than batch fermentation/atmospheric distillation since the higher capital costs of the forms are more than compensated by increased production rates (Biomass Refining Newsletter, Winter 1979).

The second assumption is that future technological change's in processing should be incorporated into these plants. The most important technology affected by this assumption is acid or enzymatic hydrolysis of cellulosic feedstocks. A properly designed ethanol facility should be able to adapt to this technology or to other cellulose conversion technologies when they become more cost competitive. The other major technological improvement that we may expect in the near future is the coupling of ethanol plants with biomass or coal gasification facilities. This latter technology will produce methanol and ammonia in a highly exothermic (heat liberating) reaction that should be sufficient to provide the process heat for a sizable ethanol distillery (Reed 1979).

A firm that has a single capital plant with which to produce a variety of products from several variable inputs will allocate these fixed resources to produce a given bundle of products at minimum cost. The analytical aspects of this situation have been given in detail in the appendix to an earlier report (Hertzmark and Gould 1979). The conclusions of that analysis carry the following implications for the biom ass refinery:

1. The ability to refine alternative inputs to a common output is crucial to the economic efficiency of the refinery.

2. The switching costs involved in going from one input mix to another or from one set of outputs to another must be minimized in design as much as the variable and fixed costs. There will of ten be a trade-off between minimizing fixed costs and minimizing the swit ching costs (Fuss and Mefadden 1978; 311-64).

3. The firm needs to make estimates of the demand curves for all of its potential products. 


\subsubsection{Feedzrains Markets}

In a truly efficient market, price information is all that is necessary to properly allocate the grains and proteins to their proper uses. The POLYSIM model contains no nonprice information such as nutritional constraints. The supply and demand equations for the various grains and protein products include own prices as well as prices of other complements or substitutes. The demand and supply functions used are implicitly the results of consumer or producer optimization so that they may be fairly said to represent the end product of the sort of optimization procedure that was used in the feed simulation report.

The linear program procedure that was used to get least-cost livestock rations for the inclusion of ethanol joint products is a type widely used in the livestock industry. It is, therefore, precisely the type of nonprice information upon which economic supply and demand functions are based.* This means that the microeconomic results from the linear programming simulation should be consistent with the results of POLYSIM if, indeed, the optimization procedure used at the microeconomic level is valid. In a sense, then, the section of the model that dealt with the interconnections of feedgrains and proteins served to validate the previous microeconomic technique.

The operation of the model in the feedgrains sector is designed to capture the price, quantity, and acreage effects of alternative ethanol programs on the variables reported as part of the model. One of the more important assumptions of the model is that the production of ethanol would be divided into two basic technologies. The first is a variant of the beverage industry technique that leads to the production of 2.5 gal. of ethanol plus $18 \mathrm{lb}$ of stillage (distillers' grains) from each bushel of corn. The second production technique is one that is more common to the food industry. The corn is preseparated into oil, gluten meal, and fermentable starch. This process gives the same yield of alcohol per bushel of corn but gives $3 \mathrm{lb}$ of oil plus $10 \mathrm{lb}$ of gluten meal. A further variation on this latter technique utilizes the fiber portion of the corn kernel as a feedstock for the production of methane.

We assumed that the production of alcohol would be evenly divided between the process that provides the distillers' grain joint product and the one that provides the gluten meal plus oil joint products. The latter technique is superior from both a technical and economic standpoint.** Unf ortunately, it does not seem well suited to the small scale of on-farm production that we expect to supply a considerable portion of the ethanol. Unlike distillers' grains, gluten meal is low in fiber and already has a place in export markets.

*'The model alluded to is a cost minimization model of the form

$\begin{array}{cl}\underset{x}{\operatorname{Min}} & C^{\prime} X \\ \text { s.t. } & A^{\prime} x \geq B,\end{array}$

where $c$ is a cost vector, $A$ is a matrix of feed characteristics, and $b$ is a vector of nu tritional and growth constraints.

**This means that the corn processor technique is less expensive at almost all input price combinations than the beverage technique. The only exception would be one in which achieving high flow rates in the distillery was considered of small importance while energy inputs were virtually free. 
Unfortunately, the authors were unable to model the effect of exporting gluten meal since foreign demand functions for the product were not available. For this reason, the estimated impacts of large ethanol production will tend to overstate the price deterioration of gluten meal and distillers' grains from what might exist with the export of the products.

The POLYSIM model accounts for changes that will take place in the corn market from the diversion of grain to alcohol production and from the addition of the joint product feeds to the protein market. Using the supply/demand relationships for corn, soybeans, protein, and land on which to grow the corn, the model simulates the decisions of farmers to plant corn, soybeans, wheat, or other crops in response to changes in the price parameters. The equations in the model relevant to determining the results on the corn market are the change in the exogenous demand for corn, additional supplies of concentrated protein, the foreign demand for com and soybeans, and the availability of land suitable for growing additional corn. Other things being equal, an exogenous increase in the demand for com should cause an unambiguous and sharp increase in its price.

There are, however, two demand functions for corn that are relevant for our purposes. The first is the domestic demand which has expected, inelastic properties (see Table 42). The second is the foreign demand, which is much more elastic in both the short and long runs. The relatively higher foreign elasticity and the effects of time in general in increasing the elasticity of the demand curve that producers face will serve to moderate potential increases in corn prices.* In the long run, both domestic and international consumers of corn are more easily able to adjust either their livestock rations or the actual numbers of livestock in response to changes in feedgrain prices. The increase in corn prices that would accompany greater production of alcohol will thus tend to be moderated by changes in the demand for corn by other consumers. Foreign demand will have a good deal of weight in the price determination process since relatively small increases in the price of corn would trigger relatively large shifts in the quantity demanded. Since corn contains a considerable amount of protein, its value is dependent not only on its caloric content but also on the value of protein at any given time. This, in turn, depends on the conditions that prevail in the soybean market and in the market for soybean meal and similar products. A large supply of high-protein products will tend to depress the value of protein per se as an animal feed. In cost-minimizing livestock rations, this will induce a greater use of these products and a fall in the demand for unprocessed grain as a feed. The remainder of the nutrition for the animals can then be obtained from a variety of low quality sources such as hay, stover, or other similar products. The supply of corn relates not only to its price but to the prices of alternative products that compete for the same land base. If com increases relative to other potential uses of the land, then there will be an increase in land used for corn. In supplydemand interaction the lags associated with changing land uses plus higher elasticities in the long run will dampen demand and will reduce the overall increase in corn acreage from what one might expect on the basis of short-run price changes alone.

*This is accomplished through a distributed lag of the form

$$
D(P t)=\eta_{s r} P_{t-1}+\lambda_{\eta} P_{t-z}+\ldots
$$

where the $t$ subscripts indicate time, $p$ is price, and $\lambda$ is a weighting factor for the lagged long-run elasticity. 
Table 4-1. COMPARATIVE ENERGY USE FOR CONVENTIONAL AND BIOMASS REFIERY SYSTEMS

\begin{tabular}{|c|c|c|c|}
\hline \multicolumn{2}{|c|}{ Conventional System } & \multicolumn{2}{|c|}{ Biomass Refinery } \\
\hline & $1000 \mathrm{Btu}$ & & $1000 \mathrm{Btu}$ \\
\hline $\begin{array}{l}\text { Agricul tural Energy } \\
\text { Corn (1 bu) }\end{array}$ & 184 & $\begin{array}{l}\text { Agricul tural Energy } \\
\text { Corn }(1 \mathrm{bu}) \\
\text { Hay }(17 \mathrm{lb})^{\mathrm{a}}\end{array}$ & $\begin{array}{r}184.0 \\
81.3\end{array}$ \\
\hline $\begin{array}{l}\text { Gasoline }(2 \mathrm{gal})^{\mathrm{b}} \\
\text { content } \\
\text { Processing }\end{array}$ & $\begin{array}{r}250 \\
50\end{array}$ & Ethanol $(2.5 \text { gal. })^{c, d}$ & $120-370$ \\
\hline Total & 484 & Total & $385-735$ \\
\hline
\end{tabular}

Source: Chambers et al. 1979, p. 791; Pimintel et al. 1975, p. 755.

${ }^{a}$ According to Hertzmark and Gould $(1979$, p. 38$)$ at a $10 \%$ dietary penetration, each pound of DDG in a dairy ration will replace about $1 \mathrm{lb}$ of corn grain and require an additional $1 \mathrm{lb}$ of alf alf a hay.

${ }^{b}$ Assume 1 gal. of ethanol is equivalent to .81 gal. of gasoline. This figure accounts for both the lower energy content and higher combustion efficiency of ethanol vis-a-vis gasoline. Thus, as a liquid fuel, ethanol has an energy content equivalent to 101,688 Btu/gal. (See Carlson et al. 1979; Chambers et al. 1979).

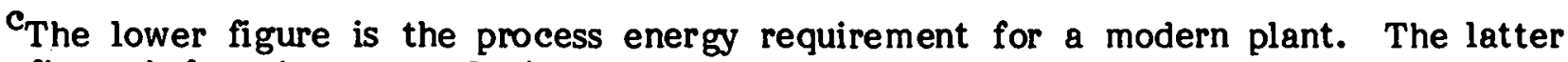
figure is for a beverage plant.

$\mathrm{d}_{\text {This }}$ figure overstates the energy use of the biomass refinery relative to the conventional system since no processing of the corn is assumed for the conventional system. 
Table 4-2. SELECTED PRICE ELASTICITIES USED IN POLYSIM

\begin{tabular}{lcc}
\multicolumn{1}{c}{ Elasticity } & Short-run & Long-run \\
\hline Own Prices & & \\
Corn (dom estic) & -0.420 & -0.840 \\
Corn (export) & -0.500 & -2.500 \\
Soybeans (dom estic) & -0.350 & -1.029 \\
Soybeans (export) & -0.565 & -2.850 \\
Soybean meal (dom estic) & -0.560 & -1.647 \\
Soybean meal (export) & -0.570 & -2.900 \\
& & \\
Cross Price a & & \\
Corn/soybean meal (domestic) & 0.060 & 0.120 \\
Grain sorghum/corn (domestic) & 0.150 & 0.300 \\
Distillers' grains/total byproducts & -0.370 & \\
Guten meal/DDG & 0.950 & \\
& & \\
Acreage & & \\
Corn/own price & 0.150 & 0.454 \\
Corn/soybean price & -0.090 & -0.273 \\
Corn/wheat price (t-1) & -0.020 & -0.061 \\
Corn/grain sorghum price & -0.030 & -0.091 \\
Soybeans/own price & 0.250 & 0.750 \\
Soybeans/corn price & -0.150 & -0.454 \\
Soybeans/wheat price & -0.020 & -0.061 \\
Soybeans/cotton price & -0.030 & -0.150 \\
\hline
\end{tabular}

Source: taken from POLYSIM

assume $\eta_{x, y}=\eta_{y, x}$ 
The substitutions just described, both direct and indirect, serve to moderate the impacts of ethanol production on the price of corn. The substitution of joint-product feeds or of other high-protein products for the protein fraction of the corn and for soybean meal serves to minimize the affects of the additional land required even when large amounts of corn are used in alcohol production.

Another major area of concern is ethanol's effect on the soybean market. Logically, one would be hard-pressed to maintain that producing ethanol from com would greatly increase the price of corn and depress the price of soybeans and meal simultaneously when considering the agricultural economy as a whole. There are two good reasons why this is not possible. The first is that a considerable portion of the value of snrn results f rmm the protein contained theroin. Sccond, com and soybeais are yruwn on much of the same land throughout the Midwest. Any dramatic changes in the ratio of corn to soybean prices would be mitigated by shifts out of soybeans and into corn. This will obviously slow the increases in the price of corn at the same time that it reduce's the fall in soybean prices. As with the corn market, the export market for soybeans and soybean meal shows a considerably more elastic demand than does the domestic market. This allows relatively small declines in the price of soybeans to be translated into large increases in exports of both beans and meal.

\subsection{ANALYSIS RESULTS}

Resul ts of the previous analysis generally follow the reasoning presented there, although some elaboration on the meaning of these results may be called for. The simulations run from 1979-1983, inclusive, incorporating production levels of 200, 350,500, 750, 1,000, and 3,000 million gal./yr by 1983. In each case, the build-up in alcohol production followed a steady, arithmetic progression starting urith the current year. Throughout the simulations, an even split between distillers' grains and gluten meal was assumed. The stochastic runs are reported separately since analysis of those results will differ greatly from the analysis of the deterministic runs. As a caveat, we should note that these results are not intended to be perfectly accurate or predictive in a quantitive sense. Rather, they are expected to be accurate as to both the direction and the relative magnitude of the changes that alcohol production will bring to the agricultural sector.

One problem that exists in perf orming simulations diring an inflationary era is tho propcr way to account for this effect. The POLYSIM model is run on a current dollar basis. Unfortunately, during a period of inflation it is very difficult to interpret the meaning of sm all changes in prices. This problem, known as the signal extraction problem, has heen the objcet of some attention in recent years (see any recent advanced macroeconomic text-e.g., Dornbusch and Fischer 1978, Chap. 16). In a real world inflationary situation, small price changes may be simply the result of inflation or of expected inflation (transmitted via the futures market in grains). Minor variations in demand and supply also cause some "noise" that is difficult to interpret-e.g., is a 5\% increase in the price of corn today the result of random factors, relative price increases, or simply general inflation? To answer this question one would need a variance components model, not part of 
the current research.* We should expect, therefore, that adjustment in the real world to a structural change in the grain markets will not be as smooth as is depicted in the POLYSIM results. What the results do indicate is that, in general, the degree to which alcohol production will be able to upset grain and protein markets is minimal. Under conditions of uncertainty, this means that a relatively small portion of the variation in grain price over the next few years can be attributed to increased alcohol production.

Looking at the model results, note that an exogenous trend of increasing demand for food and feed has been imposed on the model. This exogenous trend comes from three sources. The first is continued population and income growth in Europe and the U.S. The second is a growing list of countries whose tastes have recently come to far exceed their agricultural production capacities (e.g., Venezuela, Iran, Mexico). Lastly, as an increasing proportion of potential cropland is put under the plow, susceptibility to drought and pests requires a substantial reserve of grains. The set-aside program, then, disappears entirely. This eliminates one of the more widely touted policy alternatives to encourage the production of biomass for energy (OTA 1979, iv-v). Table 4-3 shows the summary of the exogenous trend in feed and protein demand on the other variables in the model. The most important figure in the output is that for real net farm income. This figure indicates a relative decline in the share of agriculture in overall national income if an annual growth rate of real income of $2.5 \%$ is considered the norm for the coming decade. Since this income is to be spread over an ever-decreasing number of farmers, the per-capita income in agriculture should rise at a rate faster than $0.5 \%$. However, this figure goes a long way to explain the interest of farmers in a proposal such as ethanol that promises to raise farm income.

As Table 4-3 shows, the overall demand for protein in the livestock sector grows at an annual rate of $1.5 \%$, and the larger part of that increase is taken up by the increased demand for soybean meal. The international demand for protein for feed has declined from record 1979 levels. This reduces the quantities of corn and soybeans entering international trade annually by $1.7 \%$ and $2.6 \%$, respectively. Much of the decline in raw soybean exports can be accounted for by the rise in exports of soybean meal. Additional processing within this country can be considered a benefit, since it will provide the multiplier impacts that are normally associated with increases in domestic employment and economic activity. One major aspect of the development of U.S. agriculture over the next five years will be a clear and continuous reduction in government deficiency payments to agriculture if existing programs are maintained.** This primarily results from increases in wheat and soybean prices. Soybeans become a relatively less desirable crop to grow since corn, which can be grown on the same land, is often more profitable for farmers to grow.

*A variance components model combines cross section and time series data such that each error vector $v \mathbf{i}=\delta \mathbf{i}+\delta \mathrm{t}=\epsilon \mathrm{it}$,

where $\delta \mathrm{i}$ is random with respect to (wrt) $\mathrm{i}$ (cross sections);

$\delta \mathrm{t}$ is random wrt time series; and

$\epsilon$ it is completely random.

**The impacts of the embargo on sales of grain to the U.S.S.R. may change existing programs. The extent to which support programs change will depend in large measure on whether the U.S.S.R. reduces its net grain imports. If it does not, then U.S. sales to other nations should increase as simple substitution of contracts occurs. 
Table 4-3. GROWTH OP SEI.ECTED VARIABLES IN POLYSIM (Baseline Case)

\begin{tabular}{|c|c|}
\hline Variable & Annual Growth Rate (\%) \\
\hline \multicolumn{2}{|l|}{ Demands } \\
\hline Soybean meal feed demand & 2.1 \\
\hline Total protein demand & 1.5 \\
\hline Corn feed demand & 1.3 \\
\hline \multicolumn{2}{|l|}{ Exports } \\
\hline Soybeans & -2.6 \\
\hline Soybean meal & 1.0 \\
\hline Corn & -1.7 \\
\hline \multicolumn{2}{|l|}{ Prices } \\
\hline Ċorn gluten meal & 1.6 \\
\hline Distillers' grains & 1.6 \\
\hline Soybean meal & 1.6 \\
\hline Soybeans & 0.8 \\
\hline Corn & -0.05 \\
\hline Wheat & 1.2 \\
\hline \multicolumn{2}{|l|}{ Receipts and Income } \\
\hline Soybean cash receipts & 2.3 \\
\hline Corn cash receipts & 2.0 \\
\hline Total deficiency payments & -2.9 \\
\hline Net farm income & 0.5 \\
\hline \multicolumn{2}{|l|}{ Harvested $\Lambda$ eres } \\
\hline Wheat & -0.02 \\
\hline Soybean & -1.7 \\
\hline Corn & 1.7 \\
\hline \multicolumn{2}{|l|}{ Quantities } \\
\hline Gluten meal & 0.8 \\
\hline Distillers' grains & 0.9 \\
\hline Cottonseed meal & -1.3 \\
\hline
\end{tabular}


Table 4-4 shows the results of the same exercise performed for the five ethanol scenarios. The rate of growth is calculated in comparison with the base year (the first year of production). For the two low-production scenarios ( 350 and 500 million gallons per year by 1983), this method yields approximately accurate results. The higher production scenarios require that the initial year's production be far higher than the current level in order to have a steady linear growth trend in alcohol output. It would not be appropriate to compare the base year of one scenario with the final year of another since much of the activity of the model concerns the change from short-run to long-run impacts and elasticities. One way of getting around this difficulty would be to put in exponential growth in alcohol production. This modification will be made in subsequent uses of the model during the coming year. Results conf orm generally to what one would expect. The rates of growth of demand for soybean meal and corn fall relative to the baseline case, while total protein demand is enhanced. The additional gluten meal and distillers' grains are sufficient to remove the upward price trend of those two products. In addition, the growth rate of soybean meal price is reduced because of increased availability of substitutes. The income picture for farmers is enhanced primarily through the substitution of corn for soybeans on some additional acres relative to the baseline projections.

At higher alcohol production levels, the changes in growth trends identified above intensify. The demands for com and soybeans fall of $f$ sharply while the growth rate of protein demand doubles. The trend in exports of soybeans is largely unaffected while soybean meal exports rise sharply. Exports of corn fall at a faster rate with increased ethanol production. What is essentially a minor relative price decline at the 350 and 500 million gal. levels becomes a severe deterioration at the 3,000 million gal. production level. What the table indicates is that up to 1,000 million gal. can be produced annually without seriously depreciating the value of the feed joint products. At higher production levels, there appears to be a need to promote and account for the export of at least some of these products. At 3,000 million gal. and above, export of joint products in quantities sufficient to halt the rate of decline in the price would cut into the export market for soybean meal. This would induce additional releases of soybean acres to com in an attempt to mitigate the relative price decrease of the soybean meal. Up to the 3,000 million gal. production level, there does not appear to be any significant land use impact. At the highest level included in the simulations, the acreage of wheat falls slightly, relative to the baseline, while the rate of increase in corn acreage rises at a 25\% higher level than in the baseline. Almost all of the additional acreage for the corn crop comes directly from soybean production. For at least the foreseeable future, there is apparently no need to use agricultural policy to increase the supply of land available to energy production.

The growth rates given in Tables 4-3 and 4-4 are calculated from the data that are presented in Tables 4-5 to 4-9. In considering the material presented in these tables, it is useful to note that only two quantitatively significant changes occur in the highproduction scenarios. The first is that the shif $t$ away from soybeans is accelerated. The second is that the fall in government payments is accelerated over the baseline case. Both of these developments may be considered benefits of the production of alcohol; the former because it allows farmers to substitute the relatively more profitable corn crop for soybeans, and the latter because the increased income of farmers does not come at the expense of government support programs.

According to the biomass refinery concept, the cost minimizing alcohol producer would not tolerate the type of joint-product deterioration that seems to accompany higher production levels. The behavioral conditions that we have imposed on potential alcohol 
Table 4-4. GROWTH OP SELECTED VARIABLES IN POLYSIM ALCOHOL SCENARIOS

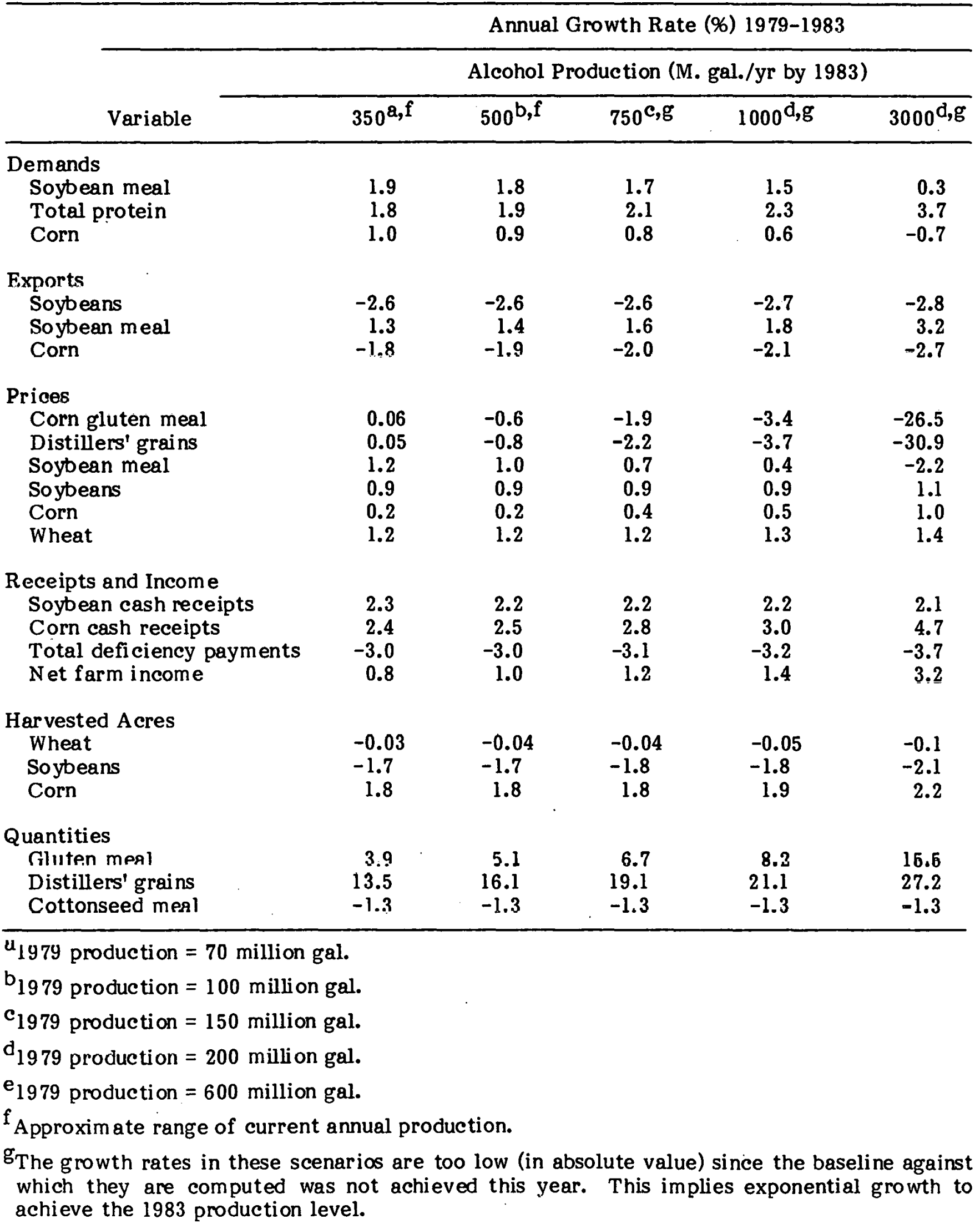


producers imply two actions that they would take in order to arrest or reverse the declining value of the feed joint products. The first and most obvious is an attempt to expand the market for these products. Gluten meal is currently exported in small quantities by the United States (Agricultural Statistics 1978; p. 37). This program could be expanded with the net result that demand for the product could rise. With the distillers' grains joint product of small-scale operations, the solution to the devaluation of the stillage would involve either drying and "export" to some other consuming area within the United States or the processing of spoiled grains. In the latter situation, the protein value of the grain is virtually nil, so that the grain has a low or nonexistent market value.

The second alternative for the distillers' grains producers points to the nature of the overall solution to devalued feed products. If producers diversify the feedstocks used in the biom ass refinery, the type of situation that appears at higher production levels should not occur. Potential al ternative feedstocks for alcohol production include sugar crops, sorghum grain, potatoes, small grains, and waste products from food processing and agricultural production (e.g., cull potatoes or spoiled grain). A flexible approach to the choice of feedstocks should obviate the danger of devaluation of the joint products. In fact, if only the larger producers were to adopt this approach, the cross price effects on smaller producers might be sufficient to prevent a decline in the value of the distillers' grains.

The final class of results has to do with the availability of additional land for either energy or food production. As it was originally posed, the land availability issue had two parts. The first was the issue of releasing land currently in set-aside or land-retirement programs. This would make available as much as 5-10 million additional acres. The second issue involves the use of various types of marginal land for crops. It was originally proposed (see, e.g., Calvin 1979) that this land be used for growing such energy crops as Jerusalem artichokes, jojoba, guayule, and sugar crops. There are some sound theoretical and practical reasons for considering this use of marginal land to be implausible in the near future and, in some cases, for the foreseeable future.* An exhaustive st udy of physical land availability for additional crops was done by the USDA (Diderickson et al. 1977). This study classified potential cropland by the type of disability. Not surprisingly, most of the land that is not now in crops would require some type of capital investments in order to be brought into annual crop production. Many disabilities, such as slope, erosion, aridity, and stoniness, leave the lands in question unsuited for row crop production and intensive cultivation. Repair of one or more of these land limitations so the land can be used as an energy plantation would be both capital and energy intensive. It appears unlikely that intensive cultivation of much marginal land solely for energy purposes would be feasible with current technology. As a final point, we should note that intensive cultivation of high-cost land would create rents for the owners of better quality land, thereby driving up the cost of good agricultural land still further.**

*Marginal land, by definition, has some deficiency that makes unit production costs for agricultural crops higher than on other, higher quality, land. One of the most serious of these production factors is that higher unit costs imply greater energy use (for irrigation or for cultivation) per unit of output. Since the concept of energy crop cultivation is in its relative infancy, studies of input/output characteristics of alternative systems should be perform ed as an initial feasibility test.

**The cost of production of a given crop un Inal'ginal land is the extensive margin of cultivation. The capitalized value of the greater (and lower cost) production on higher quality lands represents a rent to the owners of that land. The greater the unit cost differential between marginal and good cropland, the higher will be the prices of good land. Policies that strongly encourage cultivation of marginal lands will serve to widen this gap further. 
Table 4-5. BASEINE (BSLH) AND SIMULATION (SIML) DATA FOR 200 MILLION GALLONS ANNUALLY BY 1983

\begin{tabular}{|c|c|c|c|c|c|c|c|c|c|c|}
\hline \multirow[b]{2}{*}{$50 \%$ DDG } & \multicolumn{2}{|c|}{1979} & \multicolumn{2}{|c|}{1980} & \multicolumn{2}{|c|}{1981} & \multicolumn{2}{|c|}{1982} & \multicolumn{2}{|c|}{1983} \\
\hline & BSLN & SIML & BSLN & SIML & BSLN & SIML & BSLN & SIML & BSLN & SIML \\
\hline $\begin{array}{l}\text { Chng alcohol prd M. gal. } \\
\text { In terms of corn M. bu } \\
\text { Corn set-aside M. ac } \\
\text { Corn glth th. tns } \\
\text { DDG th. tns } \\
\text { Cotsd meal th. tns }\end{array}$ & $\begin{array}{c}0 \\
0 \\
2.90[ \\
1,500.00[ \\
420.00] \\
2,276.66]\end{array}$ & $\begin{array}{r}40.000 \\
16.000 \\
2.900 \\
1,540.000 \\
492.000 \\
2,276.666\end{array}$ & $\begin{array}{c}0 \\
0 \\
0.0 \\
1,510.000 \\
425.000 \\
1,901.189\end{array}$ & $\begin{array}{r}80.000 \\
32.000 \\
0.0 \\
1,590.000 \\
.569 .000 \\
1,900.883\end{array}$ & $\begin{array}{c}0 \\
0 \\
0.0 \\
1,520.000 \\
430.000 \\
1,958.130\end{array}$ & $\begin{array}{c}120.000 \\
48.000 \\
0.0 \\
1,640.000 \\
646.000 \\
1,957.793\end{array}$ & $\begin{array}{c}0 \\
0 \\
0.0 \\
1,545.000 \\
435.000 \\
2,013.212\end{array}$ & $\begin{array}{r}160.000 \\
64.000 \\
0.0 \\
1,705.000 \\
723.000 \\
2,012.931\end{array}$ & $\begin{array}{c}0 \\
0 \\
0.0 \\
1,560.000 \\
440.000 \\
2,138.402\end{array}$ & $\begin{array}{r}200.000 \\
80.000 \\
0.0 \\
1,760.000 \\
800.000 \\
2,138.138\end{array}$ \\
\hline \begin{tabular}{l}
\multicolumn{1}{c}{ Prices } \\
Corn gltn price $\$ /$ tn \\
DDG price $\$ /$ tn \\
Soyb meal price $\$ /$ tn \\
Soybean price $\$ /$ bu \\
Corn price $\$ /$ bu \\
Wheat price $\$ /$ bu
\end{tabular} & $\begin{array}{r}110.261 \\
122.624 \\
185.064 \\
6.755 \\
2.475 \\
3.235\end{array}$ & $\begin{array}{r}109.212 \\
121.395 \\
184.696 \\
6.755 \\
2.484 \\
3.234\end{array}$ & $\begin{array}{r}112.338 \\
124.933 \\
188.549 \\
7.196 \\
2.597 \\
3.434\end{array}$ & $\begin{array}{r}110.080 \\
122.290 \\
187.649 \\
7.199 \\
2.609 \\
3.435\end{array}$ & $\begin{array}{r}117.760 \\
130.964 \\
197.651 \\
7.632 \\
2.450 \\
3.266\end{array}$ & $\begin{array}{r}114.074 \\
126.649 \\
196.196 \\
7.636 \\
2.467 \\
3.268\end{array}$ & $\begin{array}{r}120.466 \\
133 . \subseteq .72 \\
202.192 \\
7 . \complement \cdot 11 \\
2 . \leq 48 \\
3.414\end{array}$ & $\begin{array}{r}115.481 \\
128.138 \\
200.089 \\
7.015 \\
2.468 \\
3.416\end{array}$ & $\begin{array}{r}119.411 \\
132.799 \\
200.421 \\
7.050 \\
2.469 \\
3.425\end{array}$ & $\begin{array}{r}113.328 \\
125.679 \\
197.742 \\
7.055 \\
2.493 \\
3.428\end{array}$ \\
\hline $\begin{array}{l}\text { Demands } \\
\text { Soyb meal fd d th. tns } \\
\text { Nonsbm by-pd fed } M \text {. tns } \\
\text { Tot pro demand } M \text {. tns } \\
\text { Inc. in by-pd fed } M \text {. tns } \\
\text { Corn feed demand } M \text {. bu } \\
\text { Wheat feed demand } M \text {. bu }\end{array}$ & $\begin{array}{r}17,997.039 \\
20.010 \\
38.00 \% \\
0.0 \\
4,200.00 \\
154.80 \%\end{array}$ & $\begin{array}{r}17,973.395 \\
20.122 \\
38.096 \\
0.112 \\
4,193.301 \\
154.983\end{array}$ & $\begin{array}{r}18,027.898 \\
20.933 \\
39.141 \\
0.0 \\
4,299.992 \\
130.212\end{array}$ & $\begin{array}{r}18,154.660 \\
21.156 \\
39.311 \\
0.224 \\
4,286.547 \\
130.492\end{array}$ & $\begin{array}{r}18,193.316 \\
21.897 \\
40.090 \\
0.0 \\
4,399.996 \\
129.748\end{array}$ & $\begin{array}{r}18,118.172 \\
22.233 \\
40.351 \\
0.336 \\
4,378.633 \\
130.159\end{array}$ & $\begin{array}{r}19,143 . \varepsilon 12 \\
21.168 \\
40.312 \\
0.0 \\
4,449.992 \\
127.477\end{array}$ & $\begin{array}{r}19,035.613 \\
21.616 \\
40.651 \\
0.448 \\
4,420.508 \\
128.002\end{array}$ & $\begin{array}{r}19,981.559 \\
20.991 \\
40.972 \\
0.0 \\
4,474.957 \\
124.891\end{array}$ & $\begin{array}{r}19,841.902 \\
21.551 \\
41.392 \\
0.560 \\
4,437.734 \\
125.522\end{array}$ \\
\hline $\begin{array}{l}\text { Exports } \\
\text { Soybean exports } M . \text { bu } \\
\text { Com exports } M \text {. bu } \\
\text { Soyb meal } \exp M \text {. bu }\end{array}$ & $\begin{array}{l}1,025.000 \\
2,500.000 \\
6,298.945\end{array}$ & $\begin{array}{r}1,025.070 \\
2,495.613 \\
6,306.309\end{array}$ & $\begin{array}{r}950.000 \\
2,200.000 \\
6,230.523\end{array}$ & $\begin{array}{r}949.766 \\
2,194.048 \\
6,249.133\end{array}$ & $\begin{array}{r}930.000 \\
2,280.000 \\
6,187.082\end{array}$ & $\begin{array}{r}929.652 \\
2,271.308 \\
6,216.910\end{array}$ & $\begin{array}{r}910.000 \\
2,300.000 \\
6,427.000\end{array}$ & $\begin{array}{r}909.609 \\
2,288.927 \\
6,470.742\end{array}$ & $\begin{array}{r}900.000 \\
2,300.000 \\
6,627.941\end{array}$ & $\begin{array}{r}899.522 \\
2,286.796 \\
6,687.262\end{array}$ \\
\hline
\end{tabular}


Table 4-5. BASETINE (BSLN) AND SIMULATION (SIML) DATA (concluded)

\begin{tabular}{|c|c|c|c|c|c|c|c|c|c|c|}
\hline \multirow[b]{2}{*}{$50 \%$ DDG } & \multicolumn{2}{|c|}{1979} & \multicolumn{2}{|c|}{1980} & \multicolumn{2}{|c|}{1981} & \multicolumn{2}{|c|}{$1982 \quad 1983$} & \multirow[b]{2}{*}{ BSLN } & \multirow[b]{2}{*}{ SIML } \\
\hline & BSLN & SIML & BSLN & SIML & BSLN & SIML & BSLN & SIML & & \\
\hline $\begin{array}{l}\text { Harvested Acres } \\
\text { Wheal har acres M. ac } \\
\text { Soybean har acres M. ac } \\
\text { Corn har acres M. ac } \\
\text { Cotton har acres M. ac }\end{array}$ & $\begin{array}{l}66.600 \\
73.420 \\
69.630 \\
13.1163\end{array}$ & $\begin{array}{l}66.600 \\
73.420 \\
69.630 \\
13.16 .3\end{array}$ & $\begin{array}{l}67.334 \\
68.912 \\
72.133 \\
10.844\end{array}$ & $\begin{array}{l}67.329 \\
68.868 \\
72.171 \\
10.842\end{array}$ & $\begin{array}{r}65.695 \\
67.320 \\
74.280 \\
\cdot 11.010\end{array}$ & $\begin{array}{l}65.685 \\
67.264 \\
74.340 \\
11.008\end{array}$ & $\begin{array}{l}64.570 \\
68.509 \\
75.235 \\
11.124\end{array}$ & $\begin{array}{l}64.557 \\
68.428 \\
75.325 \\
11.122\end{array}$ & $\begin{array}{l}66.519 \\
67.540 \\
75.878 \\
11.593\end{array}$ & $\begin{array}{l}66.501 \\
67.437 \\
75.993 \\
11.591\end{array}$ \\
\hline $\begin{array}{l}\text { Receipts and Income } \\
\text { Soybean cash rec } M \$ \\
\text { Corn casl. receipts } M \$ \\
\text { Total crop cash rec } M \$ \\
\text { Total live rash rec } M \$ \\
\text { Tot liv \& crop rec } M \$ \\
\text { Corn defiai ency pay } M \$ \\
\text { Total def payments } M \$ \\
\text { Total govt payments } M \$ \\
\text { Net farm income } M \$\end{array}$ & $\begin{array}{r}13,006.859 \\
9,892.867 \\
56,541.191 \\
65,691.937 \\
484.999 \\
0.0 \\
572.668 \\
1,727.470 \\
31,890.250\end{array}$ & $\begin{array}{r}13,005.953 \\
9,909.621 \\
56,557.836 \\
65,691.937 \\
484.999 \\
0.0 \\
570.905 \\
1,726.308 \\
31,882.375\end{array}$ & $\begin{array}{r}14,216.328 \\
10,867.363 \\
60,067.387 \\
67,817.750 \\
489.998 \\
0.0 \\
713.746 \\
2,178.578 \\
33,394.500\end{array}$ & $\begin{array}{c}14,214.055 \\
10,917.172 \\
60,117.121 \\
67,894.437 \\
489.908 \\
0.0 \\
712.480 \\
2,177.313 \\
33,503.812\end{array}$ & $\begin{array}{r}14,771.250 \\
11,075.609 \\
61,596.141 \\
72,392.750 \\
4497.362 \\
0.0 \\
810.909 \\
1,623.740 \\
35,199.562\end{array}$ & $\begin{array}{r}14,768.078 \\
11,153.348 \\
61,674.605 \\
72,488.062 \\
497.371 \\
0.0 \\
806.725 \\
1,619.556 \\
35,346.625\end{array}$ & $\begin{array}{r}14,886.387 \\
10,881.852 \\
62,698.477 \\
74,666.312 \\
506.364 \\
0.0 \\
470.811 \\
1,255.319 \\
33,853.500\end{array}$ & $\begin{array}{r}14,881.145 \\
10,986.809 \\
62,804.551 \\
74,810.437 \\
506.384 \\
0.0 \\
468.274 \\
1,252.781 \\
34,082.250\end{array}$ & $\begin{array}{r}14,569.262 \\
10,955.074 \\
63,461.230 \\
76,691.125 \\
516.686 \\
0.0 \\
495.878 \\
1,481.872 \\
32,732.625\end{array}$ & $\begin{array}{c}14,561.074 \\
11,086.734 \\
63,593.277 \\
76,866.062 \\
516.719 \\
0.0 \\
493.516 \\
1,479.510 \\
33,020.625\end{array}$ \\
\hline
\end{tabular}


Table 4-ī. EASELNE (BSIN) AND SIMULATION (SIML) DATA FOR 350 MLLON GALLONS ANNUALLY BY 1983

\begin{tabular}{|c|c|c|c|c|c|c|c|c|c|c|}
\hline \multirow[b]{2}{*}{$50 \%$ DDG } & \multicolumn{2}{|c|}{19.79} & \multicolumn{2}{|c|}{1980} & \multicolumn{2}{|c|}{1981} & \multicolumn{2}{|c|}{1982} & \multicolumn{2}{|c|}{1983} \\
\hline & BSLN & SIML & BSLN & SIML. & BSLN & SIML & BSLN & SIML & BSLN & SIML \\
\hline $\begin{array}{l}\text { Chng alcohol prd M. gal. } \\
\text { In terms of corn M. bu } \\
\text { Corn set-asi de M. ac } \\
\text { Corn gitn th. tns } \\
\text { DDG th. tns } \\
\text { Cotsd meal th. ths }\end{array}$ & $\begin{array}{c}0 \\
0 \\
2.900 \\
1,500.000 \\
420.000 \\
2,276.666\end{array}$ & $\begin{array}{r}70.000 \\
28.000 \\
2.900 \\
1,570.000 \\
546.000 \\
2,276.666\end{array}$ & $\begin{array}{c}0 \\
0 \\
0.0 \\
1,510.000 \\
425.000 \\
1,901.189\end{array}$ & $\begin{array}{r}140.000 \\
56.000 \\
0.0 \\
:, 650.000 \\
677.000 \\
1,900.655\end{array}$ & $\begin{array}{c}0 \\
0 \\
0.0 \\
1,520.000 \\
430.000 \\
1,958.130\end{array}$ & $\begin{array}{r}210.000 \\
84.000 \\
0.0 \\
1,730.000 \\
808.000 \\
1,957.546\end{array}$ & $\begin{array}{c}0 \\
0 \\
0.0 \\
1,545.000 \\
435.060 \\
2,013.212\end{array}$ & $\begin{array}{r}280.000 \\
112.000 \\
0.0 \\
1,825.000 \\
939.000 \\
2,012.674\end{array}$ & $\begin{array}{c}0 \\
0 \\
0.0 \\
1,560.000 \\
440.000 \\
2,138.402\end{array}$ & $\begin{array}{c}350.000 \\
140.000 \\
0.0 \\
1,910.000 \\
1,070.000 \\
2,137.844\end{array}$ \\
\hline $\begin{array}{l}\quad \text { Prices } \\
\text { Corn glt price } \$ / \text { tn } \\
\text { DDG price } \$ / \text { tn } \\
\text { Soyb meal price } \$ / \text { tn } \\
\text { Soybean price } \$ / \text { bu } \\
\text { Corn price } \$ / \text { bu } \\
\text { Wheat price } \$ / \text { bu }\end{array}$ & $\begin{array}{r}110.261 \\
122.624 \\
185.064 \\
6.755 \\
2.475 \\
3.233\end{array}$ & $\begin{array}{r}108.212 \\
120.225 \\
184.412 \\
6.754 \\
2.491 \\
3.234\end{array}$ & $\begin{array}{r}112.338 \\
124.933 \\
188.549 \\
7.196 \\
2.597 \\
3.434\end{array}$ & $\begin{array}{r}108.161 \\
120.045 \\
186.945 \\
7.202 \\
2.618 \\
3.436\end{array}$ & $\begin{array}{r}117.760 \\
130.964 \\
197.651 \\
7.632 \\
2.450 \\
3.266\end{array}$ & $\begin{array}{r}111.062 \\
123.123 \\
195.054 \\
7.640 \\
2.479 \\
3.269\end{array}$ & $\begin{array}{r}120.466 \\
133.972 \\
202.192 \\
7.011 \\
2.448 \\
3.414\end{array}$ & $\begin{array}{r}111.478 \\
123.453 \\
198.514 \\
7.018 \\
2.483 \\
3.418\end{array}$ & $\begin{array}{r}119.411 \\
132.799 \\
200.421 \\
7.050 \\
2.469 \\
3.425\end{array}$ & $\begin{array}{r}108.547 \\
120.084 \\
195.727 \\
7.059 \\
2.510 \\
3.430\end{array}$ \\
\hline $\begin{array}{l}\quad \text { Demands } \\
\text { Soyb meal fd } d \text { th. tns } \\
\text { Nonsbm by-pd fed } M \text {. tns } \\
\text { Tot pro demand } M \text {. tns } \\
\text { Inc. in by-pd f ed } M \text {. tns } \\
\text { Corn feed demand } M \text {. bu } \\
\text { Wheat feed demand } M \text {. bu }\end{array}$ & $\begin{array}{r}17,997.039 \\
20.010 \\
38.007 \\
0.0 \\
4,200.000 \\
154.807\end{array}$ & $\begin{array}{r}7,955.535 \\
20.206 \\
38.162 \\
0.196 \\
4,188.250 \\
155.113\end{array}$ & $\begin{array}{r}18,207.898 \\
20.933 \\
39.141 \\
0.0 \\
4,299.992 \\
130.212\end{array}$ & $\begin{array}{r}18,114.582 \\
21.324 \\
39.439 \\
0.391 \\
4.276 .305 \\
130.700\end{array}$ & $\begin{array}{r}18,193.316 \\
21.897 \\
40.090 \\
0.0 \\
4,399.996 \\
129.748\end{array}$ & $\begin{array}{r}18,062.809 \\
22.485 \\
40.547 \\
0.587 \\
4,362.434 \\
130.462\end{array}$ & $\begin{array}{r}.9,143.812 \\
21.163 \\
40.312 \\
0.0 \\
4,449.99 ? \\
127.477\end{array}$ & $\begin{array}{r}18,956.602 \\
21.951 \\
40.908 \\
0.783 \\
4,398.309 \\
128.391\end{array}$ & $\begin{array}{c}19,981.559 \\
20.991 \\
40.972 \\
0.0 \\
4,474.957 \\
124.891\end{array}$ & $\begin{array}{r}19,736.539 \\
21.970 \\
41.707 \\
0.979 \\
4,409.590 \\
125.989\end{array}$ \\
\hline $\begin{array}{l}\text { Exports } \\
\text { Saybean exports M. bu } \\
\text { Corn exports } M . \text { bu } \\
\text { Soyb meal } \exp M . \text { bu }\end{array}$ & $\begin{array}{l}1,025.000 \\
2,500.000 \\
6,298.945\end{array}$ & $\begin{array}{l}1,025.124 \\
2,492.305 \\
6,311.789\end{array}$ & $\begin{array}{r}950.000 \\
2,200.000 \\
6,230.523\end{array}$ & $\begin{array}{r}949.602 \\
2189.526 \\
\stackrel{5}{1} 263.031\end{array}$ & $\begin{array}{r}930.000 \\
2,280.000 \\
6,187.082\end{array}$ & $\begin{array}{r}929.403 \\
2,264.750 \\
6,239.578\end{array}$ & $\begin{array}{r}910.000 \\
2,300.001 \\
6,427.000\end{array}$ & $\begin{array}{r}909,326 \\
2,280.607 \\
6,504.160\end{array}$ & $\begin{array}{r}900.000 \\
2,300.000 \\
6,627.941\end{array}$ & $\begin{array}{r}899.184 \\
2,276.845 \\
6,731.371\end{array}$ \\
\hline
\end{tabular}


Table 4-6. BASELNE (BSLN) AND SIMULATION (SIML) DATA (concluded)

\begin{tabular}{|c|c|c|c|c|c|c|c|c|c|c|}
\hline \multirow[b]{2}{*}{$50 \%$ DDG } & \multicolumn{2}{|c|}{1979} & \multicolumn{2}{|c|}{1980} & \multicolumn{2}{|c|}{1981} & \multicolumn{2}{|c|}{1982} & \multicolumn{2}{|c|}{1983} \\
\hline & BSLN & SIML & BSLN & SIML & BSLN & SIML & BSLN & SIML & BSLN & SIML \\
\hline $\begin{array}{l}\text { Harvested Acres } \\
\text { Wheat har acres M. ac } \\
\text { Soybean l:ar acres M. ac } \\
\text { Corn har acres M. ac } \\
\text { Cotton har acres M. ac }\end{array}$ & $\begin{array}{l}66.600 \\
73.420 \\
69.630 \\
13.163\end{array}$ & $\begin{array}{l}66.600 \\
73.420 \\
69.630 \\
13.163\end{array}$ & $\begin{array}{l}67.334 \\
68.912 \\
72.133 \\
10.844\end{array}$ & $\begin{array}{r}67.325 \\
68.837 \\
72.199 \\
\cdot 10.841\end{array}$ & $\begin{array}{l}65.695 \\
67.320 \\
74.280 \\
11.010\end{array}$ & $\begin{array}{l}65.677 \\
67.223 \\
74.385 \\
11.006\end{array}$ & $\begin{array}{l}64.570 \\
68.509 \\
75.235 \\
11.124\end{array}$ & $\begin{array}{l}64.547 \\
68.369 \\
75.392 \\
11.121\end{array}$ & $\begin{array}{l}66.519 \\
67.540 \\
75.878 \\
11.593\end{array}$ & $\begin{array}{l}66.488 \\
67.360 \\
76.079 \\
11.589\end{array}$ \\
\hline $\begin{array}{l}\text { Receipts and Income } \\
\text { Soybean cash rec } M \$ \\
\text { Corn cash receipts } M \$ \\
\text { Total crop cash rec } M \$ \\
\text { Total live cash rec } M \$ \\
\text { Tot liv \& crop rec } M \$ \\
\text { Com deficiency pay } M \$ \\
\text { Total def payments } M \$ \\
\text { Total govt payments } M \$ \\
\text { Net farm income } M \$\end{array}$ & $\begin{array}{r}13,006.859 \\
9,892.867 \\
56,541.101 \\
65,691.937 \\
484.599 \\
0.0 \\
572.068 \\
1,727.470 \\
31,890.250\end{array}$ & $\begin{array}{r}13,005.309 \\
9,922.055 \\
56,570.187 \\
65,691.937 \\
484.959 \\
0.0 \\
570.131 \\
1,725.533 \\
31,877.250\end{array}$ & $\begin{array}{r}14,216.328 \\
10,867.363 \\
60,067.387 \\
67,817.750 \\
489.998 \\
0.0 \\
713.746 \\
2,178.578 \\
33,394.500\end{array}$ & $\begin{array}{r}14,212.523 \\
10,954.078 \\
60,154.078 \\
67,951.437 \\
489.998 \\
0.0 \\
711.601 \\
2,176.433 \\
33,587.312\end{array}$ & $\begin{array}{c}14,771.250 \\
11,075.609 \\
61,596.141 \\
72,392.750 \\
497.362 \\
0.0 \\
810.909 \\
1,623.740 \\
35,199.562\end{array}$ & $\begin{array}{r}14,766.043 \\
11,210.891 \\
61,732.934 \\
72,558.250 \\
497.379 \\
0.0 \\
803.656 \\
1,616.487 \\
35,458.812\end{array}$ & $\begin{array}{r}14,886.387 \\
10,881.852 \\
62,698.477 \\
74,666.312 \\
506.364 \\
0.0 \\
470.811 \\
1,255.319 \\
33,853.500\end{array}$ & $\begin{array}{r}14,877.359 \\
11,064.777 \\
62,883.359 \\
74,916.937 \\
506.400 \\
0.0 \\
466.397 \\
1,250.905 \\
34,253.312\end{array}$ & $\begin{array}{r}14,569.262 \\
10,955.074 \\
63,461.230 \\
76,691.125 \\
516.686 \\
0.0 \\
495.878 \\
1,481.872 \\
32,732.625\end{array}$ & $\begin{array}{r}14,554.805 \\
11,184.637 \\
63,691.215 \\
76,995.750 \\
516.746 \\
0.0 \\
491.698 \\
1,477.692 \\
33,237.937\end{array}$ \\
\hline
\end{tabular}


Table 4-7. BASEIINE (BSLN) AND SIMULATION (SIML) DATA FOR 500 MLLLON GAILLONS ANNUALLY BY 1983

\begin{tabular}{|c|c|c|c|c|c|c|c|c|c|c|}
\hline \multirow[b]{2}{*}{$50 \%$ DDG } & \multicolumn{2}{|c|}{1979} & \multicolumn{2}{|c|}{1980} & \multicolumn{2}{|c|}{1981} & \multicolumn{2}{|c|}{1982} & \multicolumn{2}{|c|}{1983} \\
\hline & BSLN & SEML & BSLN & SIML & BSLN & SIML & BSINN & SIML & BSLN & SIBIL \\
\hline $\begin{array}{l}\text { Chng alcoliol prd M. gel. } \\
\text { In terms of corn M. bu } \\
\text { Corn set-aside M. ac } \\
\text { Corn gitn th. tns } \\
\text { DDG th. tns } \\
\text { Cotsd meal th. tns }\end{array}$ & $\begin{array}{r}0.0 \\
0.0 \\
2.900 \\
1,500.000 \\
420.00 \mathrm{C} \\
2,276.66 \mathrm{G}\end{array}$ & $\begin{array}{r}100.000 \\
40.000 \\
2.900 \\
1,600.000 \\
600.000 \\
2,276.666\end{array}$ & $\begin{array}{c}0 \\
0 \\
0.0 \\
1,510.000 \\
425.000 \\
1,901.189\end{array}$ & $\begin{array}{c}200.000 \\
80.000 \\
0.0 \\
1,710.000 \\
785.000 \\
!, 900.423\end{array}$ & $\begin{array}{c}0 \\
0 \\
0.0 \\
1,520.000 \\
430.000 \\
1,958.130\end{array}$ & $\begin{array}{c}300.000 \\
120.000 \\
0.0 \\
1,820.000 \\
970.000 \\
1,957.274\end{array}$ & $\begin{array}{c}0 \\
0 \\
0.0 \\
1,5 \leq 5.040 \\
435.360 \\
2,013.212\end{array}$ & $\begin{array}{c}400.000 \\
160.000 \\
0.0 \\
1,945.000 \\
1,155.000 \\
2,012.467\end{array}$ & $\begin{array}{c}0 \\
0 \\
0.0 \\
1,560.000 \\
440.000 \\
2,138.402\end{array}$ & $\begin{array}{c}500.000 \\
200.000 \\
0.0 \\
2,060.000 \\
1,340.000 \\
2,137.663\end{array}$ \\
\hline \begin{tabular}{l}
\multicolumn{1}{c}{ Prices } \\
Corn gltn price $\$ / \mathrm{tn}$ \\
DDG price $\$ / \mathrm{tn}$ \\
Soyb meal price $\$ / \mathrm{tn}$ \\
Soybean price $\$ / \mathrm{bu}$ \\
Corn price $\$ / \mathrm{bu}$ \\
Wheat price $\$ / \mathrm{bu}$
\end{tabular} & $\begin{array}{r}110.261 \\
122.624 \\
185.064 \\
6.755 \\
2.475 \\
3.233\end{array}$ & $\begin{array}{r}107.209 \\
119.051 \\
184.114 \\
6.753 \\
2.497 \\
3.234\end{array}$ & $\begin{array}{r}112.338 \\
124.933 \\
188.549 \\
7.196 \\
2.597 \\
3.434\end{array}$ & $\begin{array}{r}106.241 \\
117.797 \\
186.244 \\
7.204 \\
2.627 \\
3.436\end{array}$ & $\begin{array}{r}117.760 \\
130.964 \\
197.651 \\
7.632 \\
2.450 \\
3.266\end{array}$ & $\begin{array}{r}108.054 \\
119.603 \\
193.945 \\
7.643 \\
2.491 \\
3.270\end{array}$ & $\begin{array}{r}123.566 \\
133.572 \\
203.192 \\
9.011 \\
2.44 .3 \\
3.414\end{array}$ & $\begin{array}{r}107.495 \\
118.790 \\
196.941 \\
7.011 \\
2.498 \\
3.420\end{array}$ & $\begin{array}{r}119.411 \\
132.799 \\
200.421 \\
7.055 \\
2.469 \\
3.425\end{array}$ & $\begin{array}{r}103.775 \\
114.497 \\
193.735 \\
7.065 \\
2.528 \\
3.432\end{array}$ \\
\hline $\begin{array}{l}\quad \text { Demands } \\
\text { Soyb meal fd d th. ths } \\
\text { Nonsbm by-pd f ed } M \text {. tns } \\
\text { Tot pro demand } M \text {. tns } \\
\text { Inc. in by-pd fed } M \text {. tns } \\
\text { Corn feed demand } M \text {. bu } \\
\text { Wheat feed demand } M \text {. tu }\end{array}$ & $\begin{array}{r}17,097.039 \\
20.010 \\
38.007 \\
0.0 \\
4,200.000 \\
154.807\end{array}$ & $\begin{array}{r}17,937.395 \\
20.290 \\
38.228 \\
0.280 \\
4,183.199 \\
155.244\end{array}$ & $\begin{array}{r}1 B, 207.898 \\
20.933 \\
39.141 \\
0.0 \\
+, 299.992 \\
130.212\end{array}$ & $\begin{array}{r}\text { IB } 075.508 \\
21.492 \\
39.567 \\
0.559 \\
4,266.141 \\
130.909\end{array}$ & $\begin{array}{r}18,193.316 \\
21.897 \\
40.090 \\
0.0 \\
4,399.996 \\
129.748\end{array}$ & $\begin{array}{r}18,007.305 \\
22.736 \\
40.744 \\
0.839 \\
4,346.148 \\
130.765\end{array}$ & $\begin{array}{r}19,142.81: \\
21.13 E \\
40.315 \\
0.0 \\
1,449.992 \\
127.4 \div 7\end{array}$ & $\begin{array}{r}18,876.379 \\
22.287 \\
41.164 \\
1.119 \\
4,376.098 \\
128.779\end{array}$ & $\begin{array}{r}10,981.559 \\
20.991 \\
40.972 \\
0.0 \\
4,474.957 \\
124.891\end{array}$ & $\begin{array}{r}19,630.824 \\
22.390 \\
42.021 \\
1.399 \\
4,381.477 \\
126.457\end{array}$ \\
\hline $\begin{array}{l}\text { Exports } \\
\text { Soybean exports M. bu } \\
\text { Corn exports } M . \text { bu } \\
\text { Soyb meal exp M. bu }\end{array}$ & $\begin{array}{l}1,025.000 \\
2,500.000 \\
6,298.945\end{array}$ & $\begin{array}{l}1,025.179 \\
2,489.014 \\
6,317.168\end{array}$ & $\begin{array}{r}950.000 \\
\varepsilon, 200.000 \\
\mathrm{f}, 230.523\end{array}$ & $\begin{array}{r}349.438 \\
2, ! 185.046 \\
6, \pm 77.289\end{array}$ & $\begin{array}{r}930.000 \\
2,280.000 \\
6,187.082\end{array}$ & $\begin{array}{r}929.153 \\
2,258.144 \\
6,262.176\end{array}$ & $\begin{array}{r}910.000 \\
\approx, 300.000 \\
\epsilon, 427.000\end{array}$ & $\begin{array}{r}909.046 \\
2,272.320 \\
6,537.113\end{array}$ & $\begin{array}{r}900.000 \\
2,300.000 \\
6,627.941\end{array}$ & $\begin{array}{r}898.715 \\
2,266.905 \\
6,775.367\end{array}$ \\
\hline
\end{tabular}


Table 4-7. BASEINNE (BSLN) AND SIMULATTON (SIML) DATA (concluded)

\begin{tabular}{|c|c|c|c|c|c|c|c|c|c|c|}
\hline \multirow[b]{2}{*}{ 50\% DDG } & \multicolumn{2}{|c|}{$\cdot 1979$} & \multicolumn{2}{|c|}{1980} & \multicolumn{2}{|c|}{1981} & \multicolumn{2}{|c|}{1982} & \multicolumn{2}{|c|}{1983} \\
\hline & BSLN & SIML & BSLN & SIML & BSLN & SIML & BSLN & SIML & BSLN & SIML \\
\hline $\begin{array}{l}\text { Harvested Acres } \\
\text { Wheat har acres M. ac } \\
\text { Soybean har acres M. ac } \\
\text { Corn har acres M. ac } \\
\text { Cotton har acres M. ac }\end{array}$ & $\begin{array}{l}66.600 \\
73.420 \\
69.630 \\
13.163\end{array}$ & $\begin{array}{l}66.600 \\
73.420 \\
69.630 \\
13.163\end{array}$ & $\begin{array}{l}67.334 \\
68.912 \\
72.133 \\
10.844\end{array}$ & $\begin{array}{l}67.321 \\
68.806 \\
72.227 \\
10.840\end{array}$ & $\begin{array}{l}65.695 \\
67.320 \\
74.280 \\
11.010\end{array}$ & $\begin{array}{l}65.670 \\
67.181 \\
74.430 \\
11.005\end{array}$ & $\begin{array}{l}64.570 \\
68.509 \\
75.235 \\
11.124\end{array}$ & $\begin{array}{l}64.537 \\
68.310 \\
75.459 \\
11.119\end{array}$ & $\begin{array}{l}66.519 \\
67.540 \\
75.878 \\
11.593\end{array}$ & $\begin{array}{l}66.475 \\
67.284 \\
76.164 \\
11.587\end{array}$ \\
\hline $\begin{array}{l}\text { Receipts and Ineome } \\
\text { Soybean cash rec } M \$ \\
\text { Corn cash receipts } M \$ \\
\text { Total crop cash rec } M \$ \\
\text { Total live cash ree } M \$ \\
\text { Tot liv \& crop rec } M \$ \\
\text { Com deficiency pay } M \$ \\
\text { Total def payments } M \$ \\
\text { Total govt payments } M \$ \\
\text { Net farm income } M \$\end{array}$ & $\begin{array}{r}13,005.859 \\
9,892.867 \\
56,541.191 \\
65,691.937 \\
484.999 \\
8.0 \\
57 \AA .068 \\
1,727.470 \\
31,890.250\end{array}$ & $\begin{array}{r}13,004.711 \\
9,934.547 \\
56,582.672 \\
65,691.937 \\
484.999 \\
0.0 \\
569.299 \\
1,724.701 \\
31,872.587\end{array}$ & $\begin{array}{r}14,216.328 \\
10,867.363 \\
60,067.387 \\
67,817.750 \\
489.998 \\
0.0 \\
713.746 \\
2,178.578 \\
33,394.500\end{array}$ & $\begin{array}{r}14,210.965 \\
10,991.230 \\
60,191.301 \\
68,008.687 \\
489.998 \\
0.0 \\
710.673 \\
2,175.505 \\
33,671.000\end{array}$ & $\begin{array}{r}14,771.250 \\
11,075.609 \\
61,596.141 \\
72,392.750 \\
497.362 \\
0.0 \\
810.909 \\
1,623.740 \\
35,199.562\end{array}$ & $\begin{array}{c}14,763.727 \\
11,268.574 \\
61,791.199 \\
72,629.000 \\
497.386 \\
0.0 \\
800.525 \\
1,613.356 \\
35,571.365\end{array}$ & $\begin{array}{c}14,886.387 \\
10,881.852 \\
62,698.477 \\
74,666.312 \\
506.364 \\
0.0 \\
470.811 \\
1,255.319 \\
33,853.500\end{array}$ & $\begin{array}{r}14,873.359 \\
11,142.465 \\
62,961.832 \\
75,022.187 \\
506.417 \\
0.0 \\
464.417 \\
1,248.924 \\
34,424.187\end{array}$ & $\begin{array}{r}14,569.262 \\
10,955.074 \\
63,461.230 \\
76,691.125 \\
516.686 \\
0.0 \\
495.878 \\
1,481.872 \\
32,732.625\end{array}$ & $\begin{array}{r}14,550.355 \\
11,282.625 \\
63,791.152 \\
77,124.562 \\
516.774 \\
0.0 \\
489.936 \\
1,475.929 \\
33,456.937\end{array}$ \\
\hline
\end{tabular}


Table 18. BASCIIINE (BSLN) AND SIMUL ATION ISIML) DATA POR 750 MLLION GALLONS ANNUALLY BY 1983

\begin{tabular}{|c|c|c|c|c|c|c|c|c|c|c|}
\hline \multirow{2}{*}{$50 \%$ DDG } & \multicolumn{2}{|c|}{1979} & \multicolumn{2}{|c|}{$1 \exists E 0$} & \multicolumn{2}{|c|}{1981} & \multicolumn{2}{|c|}{1982} & \multicolumn{2}{|c|}{1983} \\
\hline & BSI.N & SIML & BSLM & SIML & BSLN & SIML & BSLN & SIML & BSLN & SIML \\
\hline $\begin{array}{l}\text { Ching alcohol prd M. gal. } \\
\text { In terms of corn M. bu } \\
\text { Corn set-aside M. ac } \\
\text { Corn git th th. tns } \\
\text { DDG th. tns } \\
\text { Cotsd meal th. tns }\end{array}$ & $\begin{array}{r}0 \\
0 \\
2.900 \\
1,500.300 \\
420.300 \\
2,276 . .366\end{array}$ & $\begin{array}{r}150.000 \\
60.000 \\
2.900 \\
1.650 .600 \\
690.600 \\
2.276 .666\end{array}$ & $\begin{array}{c}0 \\
0 \\
0.0 \\
1,510.000 \\
425.000 \\
1,901.189\end{array}$ & $\begin{array}{c}300.300 \\
120.300 \\
0.3 \\
1,81,0.900 \\
965.300 \\
1,900.038\end{array}$ & $\begin{array}{c}0 \\
0 \\
0.0 \\
1,520.000 \\
430.000 \\
1,958.130\end{array}$ & $\begin{array}{c}450.00 J \\
180.003 \\
0.0 \\
1,970.003 \\
1,240.003 \\
1,956.825\end{array}$ & $\begin{array}{c}10 \\
0 \\
0.0 \\
1,545.000 \\
4 \approx 5.000 \\
2,013.212\end{array}$ & $\begin{array}{c}600.000 \\
240.000 \\
0.0 \\
2,145.000 \\
1,515.000 \\
2,012.071\end{array}$ & $\begin{array}{c}0 \\
0 \\
0.0 \\
1,560.000 \\
440.000 \\
2,138.402\end{array}$ & $\begin{array}{c}750.000 \\
300.000 \\
0.0 \\
2,310.000 \\
1,789.999 \\
2,137.260\end{array}$ \\
\hline $\begin{array}{l}\quad \text { Prices } \\
\text { Corn gl tn price } \$ / \text { tn } \\
\text { DDG price } \$ / \text { tn } \\
\text { Soyb meal price } \$ / \text { tn } \\
\text { Soybean price } \$ / \text { bu } \\
\text { Corn price } \$ / \text { bu } \\
\text { Wheat price } \$ / \text { tu }\end{array}$ & $\begin{array}{r}110.261 \\
122.264 \\
185.064 \\
6.755 \\
2.475 \\
3.233\end{array}$ & $\begin{array}{r}105.540 \\
117.098 \\
183.6 .42 \\
6.752 \\
2.508 \\
3.235\end{array}$ & $\begin{array}{r}112.388 \\
124.913 \\
188.519 \\
7.196 \\
2.597 \\
3.434\end{array}$ & $\begin{array}{r}103.1037 \\
114.047 \\
185.118 \\
7.208 \\
2.642 \\
3.438\end{array}$ & $\begin{array}{r}117.760 \\
130.964 \\
197.651 \\
7.632 \\
2.450 \\
3.266\end{array}$ & $\begin{array}{r}103.055 \\
113.750 \\
192.136 \\
7.648 \\
2.511 \\
3.272\end{array}$ & $\begin{array}{r}18.0 .466 \\
153.972 \\
202.192 \\
7.011 \\
2.448 \\
3.414\end{array}$ & $\begin{array}{r}100.877 \\
111.044 \\
194.334 \\
7.027 \\
2.522 \\
3.423\end{array}$ & $\begin{array}{r}119.411 \\
132.799 \\
200.421 \\
7.050 \\
2.469 \\
3.425\end{array}$ & $\begin{array}{r}95.794 \\
105.157 \\
190.410 \\
7.072 \\
2.558 \\
3.436\end{array}$ \\
\hline $\begin{array}{l}\text { Demands } \\
\text { Soyb meal } f d d \text { th. tns } \\
N \text { onsbm by-pd fed } M \text {. tns } \\
\text { Tot pro demand } M \text {. tns } \\
\text { Inc. in by-pd feci } M \text {. tns } \\
\text { Corn feed demand } M \text {. bu } \\
\text { Wheat feed demand } M \text {. bu }\end{array}$ & $\begin{array}{r}17,997.039 \\
20.010 \\
38.007 \\
6.0 \\
4,200.000 \\
154.807\end{array}$ & $\begin{array}{r}18,907.629 \\
20.430 \\
38.338 \\
0.420 \\
4,174.824 \\
155.164\end{array}$ & $\begin{array}{r}18,207.838 \\
20.933 \\
39.141 \\
0.0 \\
4,299.992 \\
130.212\end{array}$ & $\begin{array}{r}18,009.464 \\
21.771 \\
39.781 \\
0.839 \\
4,249.109 \\
131.257\end{array}$ & $\begin{array}{r}18,193.316 \\
21.897 \\
40.090 \\
0.0 \\
4,399.996 \\
129.748\end{array}$ & $\begin{array}{r}17,913.822 \\
23.156 \\
41.070 \\
1.25 .9 \\
4,319.219 \\
131.256\end{array}$ & $\begin{array}{r}19,1.13 .812 \\
21.168 \\
90.312 \\
0.0 \\
4,499.992 \\
137.477\end{array}$ & $\begin{array}{r}18,741.336 \\
22.847 \\
41.588 \\
1.679 \\
4,339.086 \\
129.429\end{array}$ & $\begin{array}{r}19,981.559 \\
20.991 \\
40.972 \\
0.0 \\
4,474.957 \\
124.891\end{array}$ & $\begin{array}{r}19,455.770 \\
23.090 \\
42.545 \\
2.099 \\
4,334.676 \\
127.237\end{array}$ \\
\hline \begin{tabular}{l}
\multicolumn{1}{c}{ Exports } \\
Soybean exports M. bu \\
Com exports M. bu \\
Soyb meal exp M. bu
\end{tabular} & $\begin{array}{l}1,025.000 \\
2,500.000 \\
6,298.945\end{array}$ & $\begin{array}{l}:, 025.268 \\
=, 483.535 \\
\mathbf{5}, 326.305\end{array}$ & $\begin{array}{r}950.000 \\
2,200.000 \\
6,230.523\end{array}$ & $\begin{array}{r}949.147 \\
2,177.494 \\
6,300.746\end{array}$ & $\begin{array}{r}930.000 \\
2,280.000 \\
6,187.082\end{array}$ & $\begin{array}{r}928.7 \\
2,247.2: 4 \\
6,299.496\end{array}$ & $\begin{array}{r}99.0 .000 \\
2,300.000 \\
6,427.000\end{array}$ & $\begin{array}{r}908.578 \\
2,258.417 \\
6,591.660\end{array}$ & $\begin{array}{r}900.000 \\
2,300.000 \\
6,627.941\end{array}$ & $\begin{array}{r}898.071 \\
2,250.312 \\
6,849.227\end{array}$ \\
\hline
\end{tabular}


Table 4-8. BASEINE (BSLN) AND SIMULATTON (SIML) DATA (concluded)

\begin{tabular}{|c|c|c|c|c|c|c|c|c|c|c|}
\hline \multirow{2}{*}{$50 \%$ JDG } & \multicolumn{2}{|c|}{1979} & \multicolumn{2}{|c|}{1980} & \multicolumn{2}{|c|}{1981} & \multicolumn{2}{|c|}{1982} & \multicolumn{2}{|r|}{1983} \\
\hline & BSLN & SIML & BSLN & SIML & BSLN & SIML & BSLN & SIML & BSLN & SIML \\
\hline $\begin{array}{l}\text { Harvested Acres } \\
\text { Wheat har acres M. ac } \\
\text { Soybean har acres M. ac } \\
\text { Corn har acres M. ac } \\
\text { Cotton har acres M. ac }\end{array}$ & $\begin{array}{l}66.600 \\
73.420 \\
69.630 \\
13.163\end{array}$ & $\begin{array}{l}66.600 \\
73.420 \\
69.630 \\
13.163\end{array}$ & $\begin{array}{l}67.334 \\
68.912 \\
72.133 \\
10.844\end{array}$ & $\begin{array}{l}67.314 \\
68.752 \\
72.275 \\
\quad 10.837\end{array}$ & $\begin{array}{l}65.695 \\
67.320 \\
74.280 \\
11.010\end{array}$ & $\begin{array}{l}65.657 \\
67.112 \\
74.505 \\
11.002\end{array}$ & $\begin{array}{l}64.570 \\
68.509 \\
75.235 \\
11.124\end{array}$ & $\begin{array}{r}64.521 \\
68.211 \\
75.570 \\
11.116\end{array}$ & $\begin{array}{l}66.519 \\
67.540 \\
75.878 \\
11.593\end{array}$ & $\begin{array}{l}66.453 \\
67.156 \\
76.307 \\
11.584\end{array}$ \\
\hline Receipts and Income & & & & & & & & & & \\
\hline $\begin{array}{l}\text { Soybean cash ree } M \$ \\
\text { Corn cash receipts } M \$ \\
\text { Total crop cash rec } M \$ \\
\text { Total live cash ree } M \$ \\
\text { Tot liv \& crop rec } M \$\end{array}$ & $\begin{array}{r}13,006.859 \\
9,892.867 \\
56,541.191 \\
65,691.937 \\
484.999\end{array}$ & $\begin{array}{r}13,003.633 \\
9,955.539 \\
56,603.629 \\
65,691.937 \\
484.999\end{array}$ & $\begin{array}{r}14,216.328 \\
10,867.363 \\
60,067.387 \\
67,817.750 \\
489.998\end{array}$ & $\begin{array}{r}14,208.164 \\
11,053.258 \\
60,253.359 \\
68,104.750 \\
489.998\end{array}$ & $\begin{array}{r}14,771.250 \\
11,075.609 \\
61,596.141 \\
72,392.750 \\
497.362\end{array}$ & $\begin{array}{r}14,759.605 \\
11,364.809 \\
61,888.203 \\
72,745.750 \\
497.399\end{array}$ & $\begin{array}{r}14,886.387 \\
10,881.852 \\
62,698.477 \\
74,666.312 \\
506.364\end{array}$ & $\begin{array}{r}14,866.508 \\
11,272.957 \\
63,093.316 \\
75,197.750 \\
506.445\end{array}$ & $\begin{array}{r}14,569.262 \\
10,955.074 \\
63,461.230 \\
76,691.125 \\
516.686\end{array}$ & $\begin{array}{r}14,540.660 \\
11,447.340 \\
63,956.707 \\
77,340.375 \\
516.819\end{array}$ \\
\hline $\begin{array}{l}\text { Corn deficiency pay } M \$ \\
\text { Total def payments } M \$ \\
\text { Total govt payments } M \$ \\
\text { Net farm income } M \$\end{array}$ & $\begin{array}{r}0.0 \\
572.068 \\
1,727.470 \\
31,890.250\end{array}$ & $\begin{array}{r}0.0 \\
567.788 \\
1,723.190 \\
31,863.875\end{array}$ & $\begin{array}{r}0.0 \\
713.746 \\
2,178.578 \\
33,394.500\end{array}$ & $\begin{array}{r}0.0 \\
709.073 \\
2,173.905 \\
33,810.625\end{array}$ & $\begin{array}{r}0.0 \\
810.909 \\
1,623.740 \\
35,199.562\end{array}$ & $\begin{array}{r}0.0 \\
795.303 \\
1,608.134 \\
35,757.125\end{array}$ & $\begin{array}{c}0.0 \\
470.811 \\
1,255.319 \\
33,853.500\end{array}$ & $\begin{array}{c}0.0 \\
461.238 \\
1,245.746 \\
34,711.562\end{array}$ & $\begin{array}{c}0.0 \\
495.878 \\
1,481.872 \\
32,732.625\end{array}$ & $\begin{array}{c}0.0 \\
486.966 \\
1,472.959 \\
33,826.500\end{array}$ \\
\hline
\end{tabular}


Table 1-9. BASLLINE (BSLN) AND SIMULATION (SIML) DATA FOR 1,000 MHLION GALLCNS ANNUALLY BY 1983

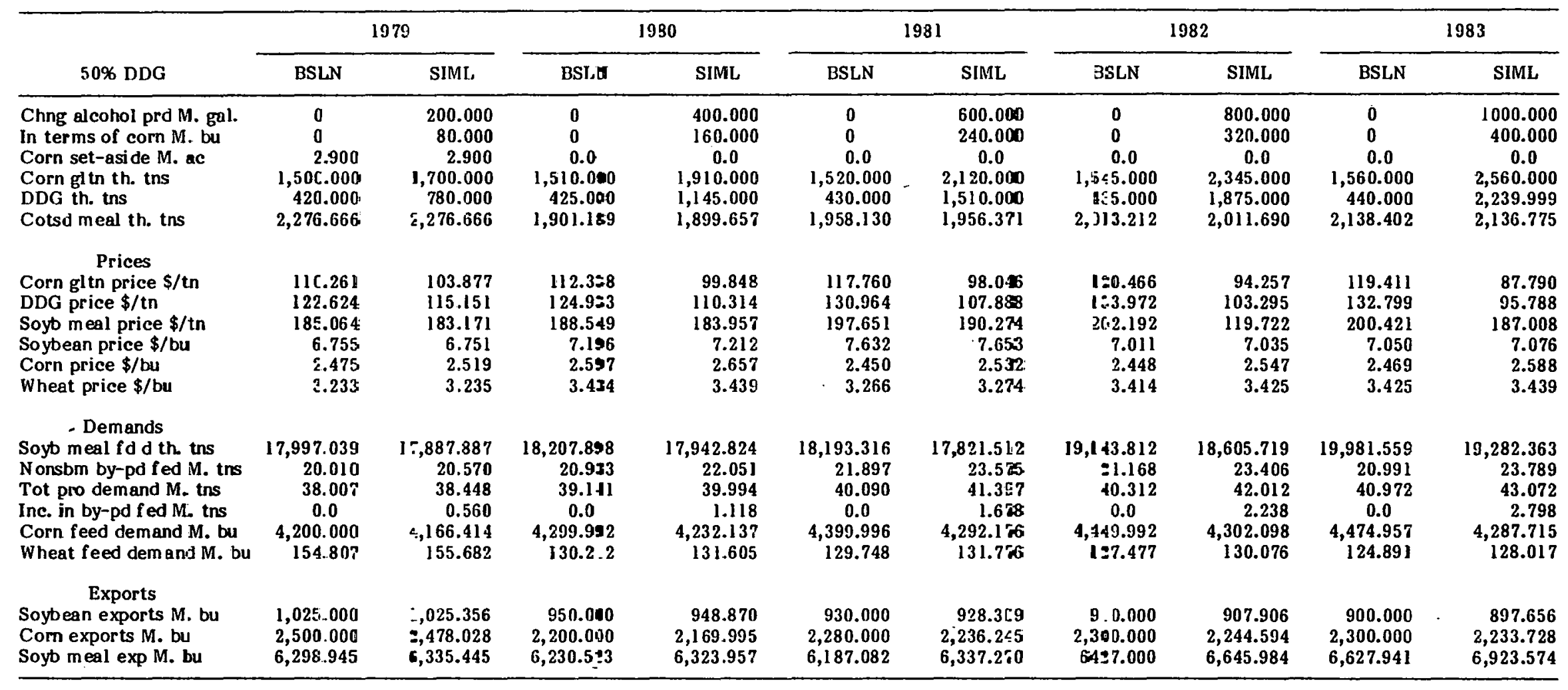


Táble: 4-9. BASEIN B (BSLN) AND SIMULATION (SIML) DATA (concluded)

\begin{tabular}{|c|c|c|c|c|c|c|c|c|c|c|}
\hline \multirow[b]{2}{*}{ 50\% DDG } & \multicolumn{2}{|c|}{1979} & \multicolumn{2}{|c|}{1980} & \multicolumn{2}{|c|}{$198 i$} & \multicolumn{2}{|c|}{1982} & \multicolumn{2}{|c|}{1983} \\
\hline & BSL.N & SIML & BSLN & SIML & BSLN & SIML & BSLN & SIML & BSLN & SIML \\
\hline $\begin{array}{l}\text { Har vested Acres } \\
\text { Wheat har acres M. ac } \\
\text { Soybean har acres M. ac } \\
\text { Corn ha: acres M. ac } \\
\text { Cotton har acres M. ac }\end{array}$ & $\begin{array}{l}66.600 \\
73.420 \\
69.630 \\
13.163\end{array}$ & $\begin{array}{l}66.600 \\
73.420 \\
69.630 \\
13.163\end{array}$ & $\begin{array}{l}67.334 \\
68.912 \\
72.133 \\
10.844\end{array}$ & $\begin{array}{l}67.307 \\
68.699 \\
72.322 \\
10.835\end{array}$ & $\begin{array}{l}65.695 \\
67.320 \\
74.280 \\
11.010\end{array}$ & $\begin{array}{l}65.645 \\
67.043 \\
74.580 \\
10.999\end{array}$ & $\begin{array}{l}64.570 \\
68.509 \\
75.235 \\
11.124\end{array}$ & $\begin{array}{l}64.505 \\
68.113 \\
75.681 \\
11.113\end{array}$ & $\begin{array}{l}66.519 \\
67.540 \\
75.878 \\
11.593\end{array}$ & $\begin{array}{l}66.431 \\
67.036 \\
76.447 \\
11.580\end{array}$ \\
\hline $\begin{array}{l}\text { Receipts and Income } \\
\text { Soybean cash rec } M \$ \\
\text { Corn cash receipts } M \$ \\
\text { Total crop cash rec } M \$ \\
\text { Total live cash rec } M \$ \\
\text { Tot liv \& crop rec } M \$ \\
\text { Corn deficiency pay } M \$ \\
\text { Total def payments } M \$ \\
\text { Total govt payments } M \$ \\
\text { Net farm income } M \$\end{array}$ & $\begin{array}{r}13,006.859 \\
9,892.867 \\
56,541.191 \\
65,691.937 \\
484.999 \\
0.0 \\
572.068 \\
1,727.470 \\
31,890.250\end{array}$ & $\begin{array}{r}13,002.543 \\
9,976.324 \\
56,624.277 \\
65,691.937 \\
484.999 \\
0.0 \\
566.454 \\
1,721.857 \\
31,855.500\end{array}$ & $\begin{array}{c}14,216.328 \\
10,867.363 \\
60,067.387 \\
67,817.750 \\
489.998 \\
0.0 \\
713.746 \\
2,178.578 \\
33,394.500\end{array}$ & $\begin{array}{r}14,205.523 \\
11,115.195 \\
60,315.322 \\
68,199.812 \\
489.998 \\
0.0 \\
707.540 \\
2,172.372 \\
33,951.125\end{array}$ & $\begin{array}{c}14,771.250 \\
11,075.609 \\
61,596.141 \\
72,392.750 \\
497.362 \\
0.0 \\
810.909 \\
1,623.740 \\
35,199.562\end{array}$ & $\begin{array}{c}14,755.898 \\
11,461.562 \\
61,986.031 \\
72,862.875 \\
497.411 \\
0.0 \\
790.115 \\
1,602.946 \\
35,947.875\end{array}$ & $\begin{array}{c}14,886.387 \\
10,881.852 \\
62,698.477 \\
74,666.312 \\
506.364 \\
0.0 \\
470.811 \\
1,255.319 \\
33,853.500\end{array}$ & $\begin{array}{r}14,862.914 \\
11,403.797 \\
63,228.363 \\
75,373.500 \\
506.474 \\
0.0 \\
458.075 \\
1,242.583 \\
35,007.062\end{array}$ & $\begin{array}{r}14,569.262 \\
10,955.074 \\
63,461.230 \\
76,691.125 \\
516.686 \\
0.0 \\
495.878 \\
1,481.872 \\
32,732.625\end{array}$ & $\begin{array}{r}14,531.523 \\
11,612.309 \\
64,123.066 \\
77,553.625 \\
516.864 \\
0.0 \\
483.864 \\
1,469.857 \\
34,201.937\end{array}$ \\
\hline
\end{tabular}


'Table 4-10. BASEINNE (BSLN) AND SIMULATION (SIML) DATA POR 3,000 MILLIOE GALLCNS ANNUALLY BY 1983

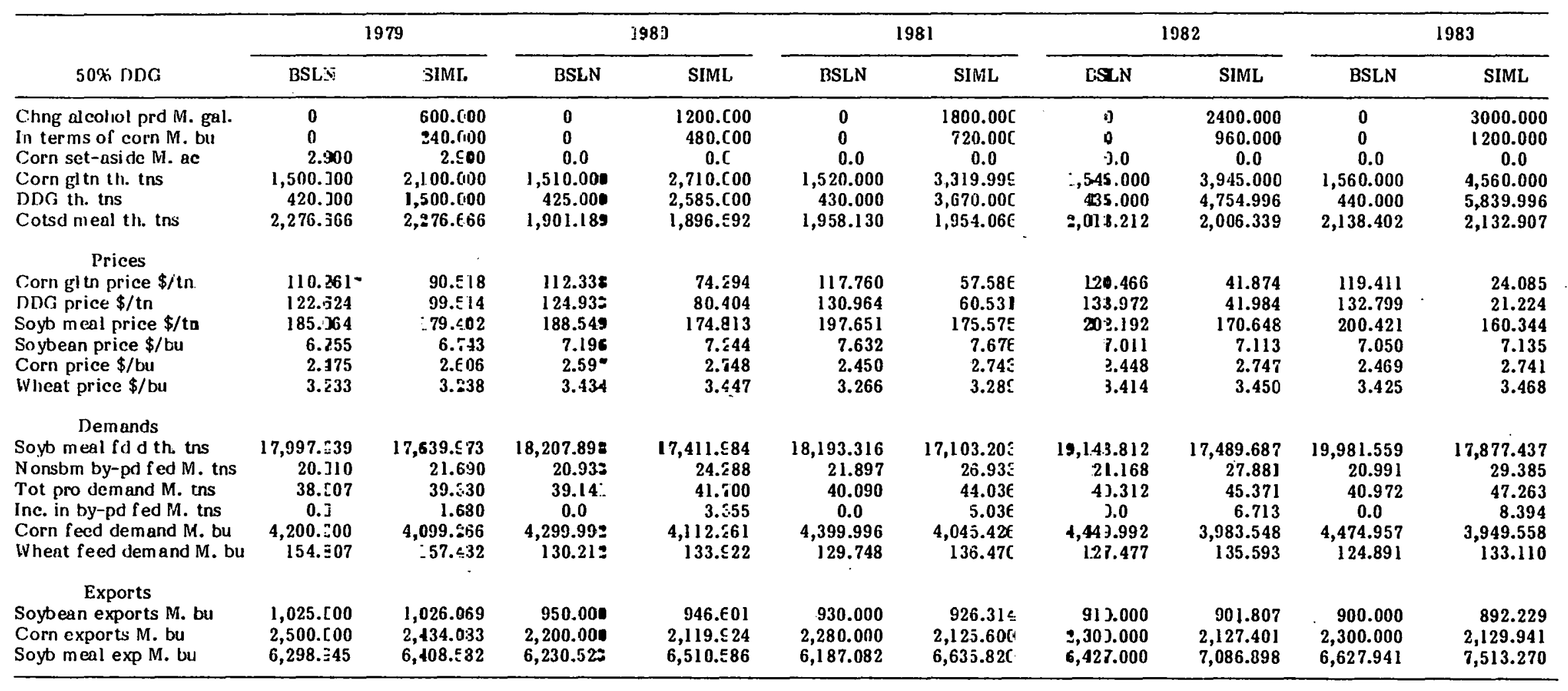


Table $4-10$. BASELINB (BSLN) AND SIMULATION (SIML) DATA (concluded)

\begin{tabular}{|c|c|c|c|c|c|c|c|c|c|c|}
\hline \multirow[b]{2}{*}{$50 \%$ DDG } & \multicolumn{2}{|c|}{1979} & \multicolumn{2}{|c|}{1980} & \multicolumn{2}{|c|}{1981} & \multicolumn{2}{|c|}{1982} & \multicolumn{2}{|c|}{1983} \\
\hline & BSL.N & SIML & BSLN & SIML & BSLN & SIML & BSLN & SIML & BSLN & SIML \\
\hline $\begin{array}{l}\text { Harvested Acres } \\
\text { Wheat har acres M. ac } \\
\text { Soybean har acres M. ac } \\
\text { Corn har acres M. ac } \\
\text { Cotton har acres M. ac }\end{array}$ & $\begin{array}{l}66.600 \\
73.420 \\
69.630 \\
13.163\end{array}$ & $\begin{array}{l}66.600 \\
73.420 \\
69.630 \\
13.163\end{array}$ & $\begin{array}{l}67.334 \\
68.912 \\
72.133 \\
10.844\end{array}$ & $\begin{array}{r}67.254 \\
68.273 \\
72.700 \\
10.817\end{array}$ & $\begin{array}{l}65.695 \\
67.320 \\
74.280 \\
11.010\end{array}$ & $\begin{array}{l}65.564 \\
66.612 \\
75.049 \\
10.983\end{array}$ & $\begin{array}{l}64.570 \\
68.509 \\
75.235 \\
11.124\end{array}$ & $\begin{array}{r}64.353 \\
67.112 \\
76.763 \\
11.079\end{array}$ & $\begin{array}{l}66.519 \\
67.540 \\
75.878 \\
11.593\end{array}$ & $\begin{array}{l}66.236 \\
66.025 \\
77.617 \\
11.549\end{array}$ \\
\hline $\begin{array}{l}\text { Receipts and Income } \\
\text { Soybean cash rec } M \$ \\
\text { Corn cash receipts } M \$ \\
\text { Total crop cash rec } M \$ \\
\text { Total live cash rec } M \$ \\
\text { Tot liv \& crop rec } M \$ \\
\text { Corn deficiency pay } M \$ \\
\text { Total dei payments } M \$ \\
\text { Total go't payments } M \$ \\
\text { Net farm income } M \$\end{array}$ & $\begin{array}{r}13,006.859 \\
9,892.867 \\
56,541.191 \\
65,691.937 \\
484.999 \\
0.0 \\
572.068 \\
1,727.470 \\
51,890.250\end{array}$ & $\begin{array}{c}12,993.875 \\
10,143.371 \\
56,790.629 \\
65,691.937 \\
484.999 \\
0.0 \\
555.147 \\
1,710.550 \\
31,795.375\end{array}$ & $\begin{array}{c}14,216.328 \\
10,867.363 \\
60,067.387 \\
67,817.750 \\
489.998 \\
0.0 \\
713.746 \\
2,178.578 \\
33,394.500\end{array}$ & $\begin{array}{r}14,183.473 \\
11,553.102 \\
60,750.785 \\
68,958.562 \\
489.998 \\
0.0 \\
697.119 \\
2,139.638 \\
35,115.687\end{array}$ & $\begin{array}{r}14,771.250 \\
11,075.609 \\
61,596.141 \\
72,392.750 \\
497.362 \\
0.0 \\
810.909 \\
1,623.740 \\
35,119.562\end{array}$ & $\begin{array}{c}14,718.922 \\
12,250.105 \\
62,777.066 \\
73,518.000 \\
497.516 \\
0.0 \\
747.364 \\
1,528.031 \\
37,058.687\end{array}$ & $\begin{array}{c}14,886.387 \\
10,881.852 \\
62,698.477 \\
74,666.312 \\
506.364 \\
0.0 \\
470.811 \\
1,255.319 \\
33,853.500\end{array}$ & $\begin{array}{r}14,815.086 \\
12,598.059 \\
64,440.766 \\
77,274.375 \\
506.656 \\
0.0 \\
429.995 \\
1,177.430 \\
38,136.312\end{array}$ & $\begin{array}{r}14,569.262 \\
10,955.074 \\
63,461.230 \\
76,691.125 \\
516.686 \\
0.0 \\
495.878 \\
1,481.872 \\
32,732.625\end{array}$ & $\begin{array}{c}14,466.539 \\
12,837.527 \\
65,365.809 \\
79,148.000 \\
517.271 \\
0.0 \\
462.172 \\
1,377.535 \\
37,360.062\end{array}$ \\
\hline
\end{tabular}


The more likely alternative for the marginal potential croplands is that they will be used to grow forage crops. Such crops as alf alf a hay can be grown under a wide variety of soil and climate conditions. The cultivational requirements may be tailored to suit the expected yield in a particular area so that the crop may return the best achievable rate of return for the farmer. Contrasting this to the rigid requirem ents of many row crops, it appears that the forage crop option would make more sense economically for both the farmer and for the economy as a whole. The results of the simulations for this paper and for the previous one clearly show that there are benefits to flexibility in an agricultural system. These benefits are difficult or impossible to quantify in any straightforward sense. However, the stochastic simulations presented in the next section will provide some insight into the economic benefits of flexibility.

With respect to the quantitative significance of the ethanol-induced price increase for corn, it is useful to note that the normal spread hetween spot prices and one-year contracts for corn is several times greater than the ethanol-induced increases in corn prices in the low production scenario. And even in the highest production scenario, the price differential attributable to ethanol is less than the one-year spot market-future market price differential. The normal approach to an analytical comparison of alternative policies is the with-and-without test-i.e., to look at the relevant variables with the project under way and to look at them again, disregarding the project. The figures of merit to compare in this case are the baseline and simulation figures for the final year of the model runs, 1983. For soybean and wheat prices, we find the baseline and simulation figures that are scarcely different from one another regardless of the level of alcohol output. For corn, the result is an increase of about $11 \%$ in 1983 for the 3,000 million gal. figure versus the baseline figure. The most dramatic impacts show up in the protein market figures. Under a maximum alcohol production scenario, the price of gluten meal declines by $80 \%$ over the 1983 baseline price. Distillers' grains show an $84 \%$ decrease while soybean meal falls by $20 \%$ over the baseline price. Given the unlikelihood of achieving such a large production figure over a short period of time, and considering the options available that were not included in the model, we feel that the drastic impacts indicated by this scenario are unlikely.

Export values of corn and soybeans remain approximately constant throughout the baseline and alcohol production scenarios. The quantity of corn exported declines by as much as 7.4\% over the baseline case, while soybeans remain approximately constant. The inelasticity of the demand curve for com is sufficient to increase the total revenues from corn exports in each scenario. Revenues from soyhean exports increase slightly. The most dram atic eff ect is the increase in exports of soybean meal (up to $13 \%$ higher in the 3 billion gal. scenario). The demand for soybean meal is more elastic than for either soybeans or corn. Since the short-run demand is still inelastic, total revenue falls.

On the income side, the increase in corn prices relative to wheat and soybeans provides an incucement for farmers to grow more corn. In the high production scenario, this shows up as an increase of $17 \%$ for corn cash receipts in the scenario versus the baseline level for 1983. Net farm income increases by about $14 \%$ in the high production scenario.

A look at these same variables for the 1,000 million gal. scenario reveals much less dramatic impacts with respect to the baseline case. Gluten meal and distillers' grains prices declined by $26 \%$ and $28 \%$, respectively. Soybean meal falls by $7 \%$ and corn prices rise by $5 \%$. The income eff ects are also less dramatic. Corn cash receipts increase by $6 \%$, while farm income in general rises by about $5 \%$. 
In the lower production scenarios, the impacts of the additional ethanol production, though evident, would in all likelihood be at or below the limit of statistical detection. The vast majority of the price or income changes are below $5 \%$. The amount of corn that would be diverted to ethanol production in the low production scenarios is much less than the normal yearly fluctuations that result from planting decisions, weather, and random variations in demand.

Figures 4-1 to 4-14 display the same information as Tables 4-5 to 4-10.

\subsection{STOCHASTIC RESULTS}

The results of the POLYSIM model when crop yields are allowed to vary randomly are presented in this section. One of the questions that of ten surround the use of agriculture as a source of liquid energy is the problem of the unpredictability of yields, both in this country and abroad. The prospect of a large part of the U.S. energy supply being dependent on the vagaries of harvest figures here and abroad is disquieting to those who remember the upset to the domestic food economy that was occasioned by the Russian wheat deal, the loss of the Peruvian anchovy, and sharp fluctuations in domestic corn yields during 1971-73. To help determine the extent to which alcohol could be a futher destabilizing factor in the agricultural sector, a series of simulation runs around the 500 million gal scenario were designed that would provide this information. The stochastic runs generated 300 different values for the yield data. This is a sufficient number of values to give some evidence on the likelihood of a "worst case" outlier with respect to crop prices and quantities. In particular, the likelihood that additional demand for corn as an energy feedstock would prove destabilizing under conditions of low domestic yields for corn and soybeans was investigated.

As in the case of the deterministic runs, the 500 million gal. figure was not enough alcohol production to significantly destabilize the agricultural sector variables of interest in this analysis. Final year (1983) results are thus quite similar to those of the deterministic run.

The stochastic analysis produced two general results. First, the variability of several important indicators shows an increase over the five-year period. That is, the variances increase over the simulation period, indicating a tendency toward greater instability. Second, the prices for corn, soybeans, and soybean meal are biased upward from the deterministic results.* For the latter reason, both net farm income and total crop receipts are higher in the stochastic runs than in the deterministic runs. The variables showing an increased deviation over the five-year period include prices, domestic demand, and exports of corn. Other factors apparently destabilized by ethanol production are the two income variables and domestic demand for soybean meal.

The interim results (1980-82) show even greater variability than the two boundary years. Presumably this is because of the difference between short- and long-run elasticities. The lower short-run values will be more destabilizing, though the variability comes down as the higher, long-run elasticities come to dominate the interactions in the model.

*This comes from a biasing of the distribution due to the existence of loan rates and support prices that limit the downward movements of prices. 
Table 4-11. STOCHASTIC SIMULATION RESULTS POR SELECTED VARIAELES, 1979 AND 1983

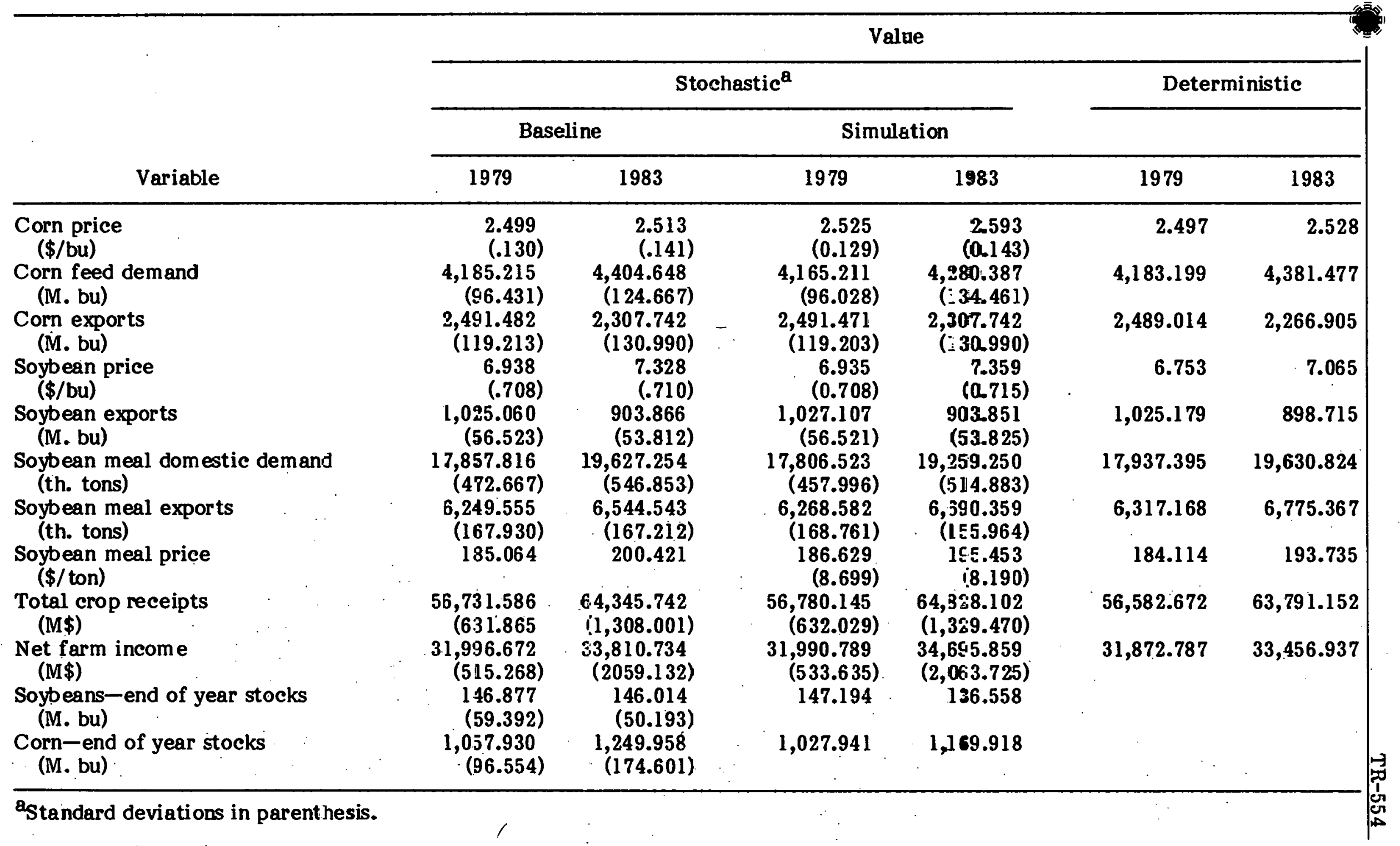


Table 4-12. EXTREME VALUES OF SELECTED VARIABLES IN STOCHASTIC SIMULATIONS

\begin{tabular}{|c|c|c|c|c|c|}
\hline \multirow{2}{*}{ Variable } & & \multicolumn{2}{|c|}{1979} & \multicolumn{2}{|c|}{1983} \\
\hline & & Minimum & Maximum & Minimum & Maximum \\
\hline $\begin{array}{l}\text { Corn price } \\
(\$ / \mathrm{bu})\end{array}$ & & 2.239 & 2.750 & 2.252 & 3.053 \\
\hline $\begin{array}{l}\text { Corn feed demand } \\
\text { (M. bu) }\end{array}$ & . & $3,972.225$ & $4,373.734$ & $3,869.979$ & $4,601.832$ \\
\hline $\begin{array}{l}\text { Corn exports } \\
\text { (M. bu) }\end{array}$ & & $2,200.711$ & $2,797.249$ & $1,909.987$ & $2,711.054$ \\
\hline $\begin{array}{l}\text { Soybean price } \\
(\$ / \mathrm{bu})\end{array}$ & & 5.595 & 9.032 & 6.071 & 9.402 \\
\hline $\begin{array}{l}\text { Soybean exports } \\
\text { (M. bu) }\end{array}$ & & 860.732 & $1,181.159$ & 728.771 & $1,088.988$ \\
\hline $\begin{array}{l}\text { Soybean meal domestic } \\
\text { (th. tons) }\end{array}$ & dem and & $16,257.277$ & $18,555.707$ & $17,563.121$ & $20,349.867$ \\
\hline $\begin{array}{l}\text { Soybean meal exports } \\
\text { (th. tons) }\end{array}$ & & $5,703.230$ & $6,565.438$ & $6,066.785$ & $6,986.434$ \\
\hline $\begin{array}{l}\text { Soybean meal price } \\
(\$ / \text { ton })\end{array}$ & & 171.327 & 215.769 & 181.323 & 227.720 \\
\hline $\begin{array}{l}\text { Total crop receipts } \\
\text { (M\$) }\end{array}$ & · & $54,967.356$ & $59,994.195$ & $61,231.633$ & $69,209.125$ \\
\hline $\begin{array}{l}\text { Net farm income } \\
(M \$)\end{array}$ & & $30,628.250$ & $34,761.438$ & $29,760.125$ & $41,214.688$ \\
\hline
\end{tabular}




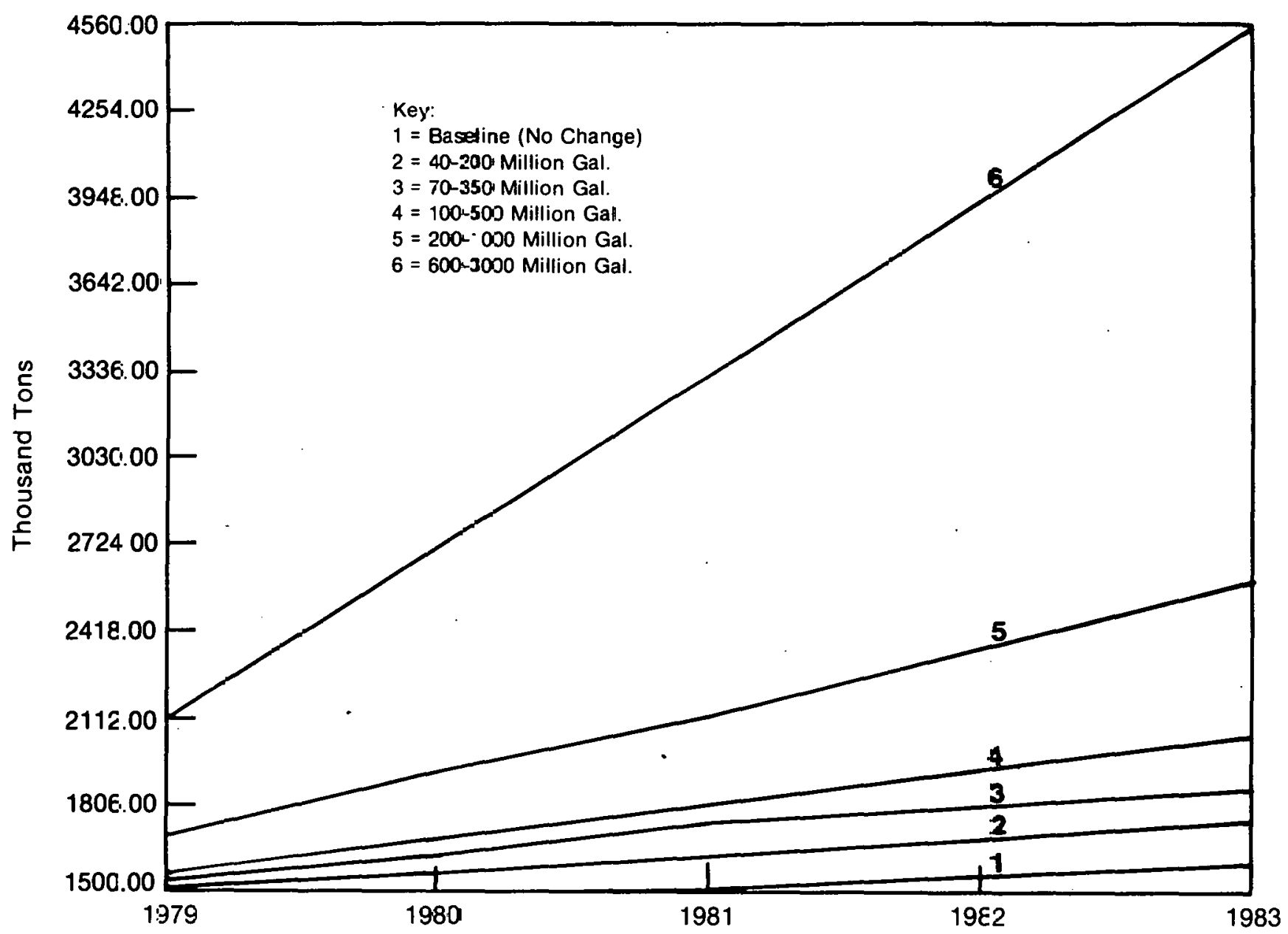

Figure 4-1. Corn Gluten Meal Fed 


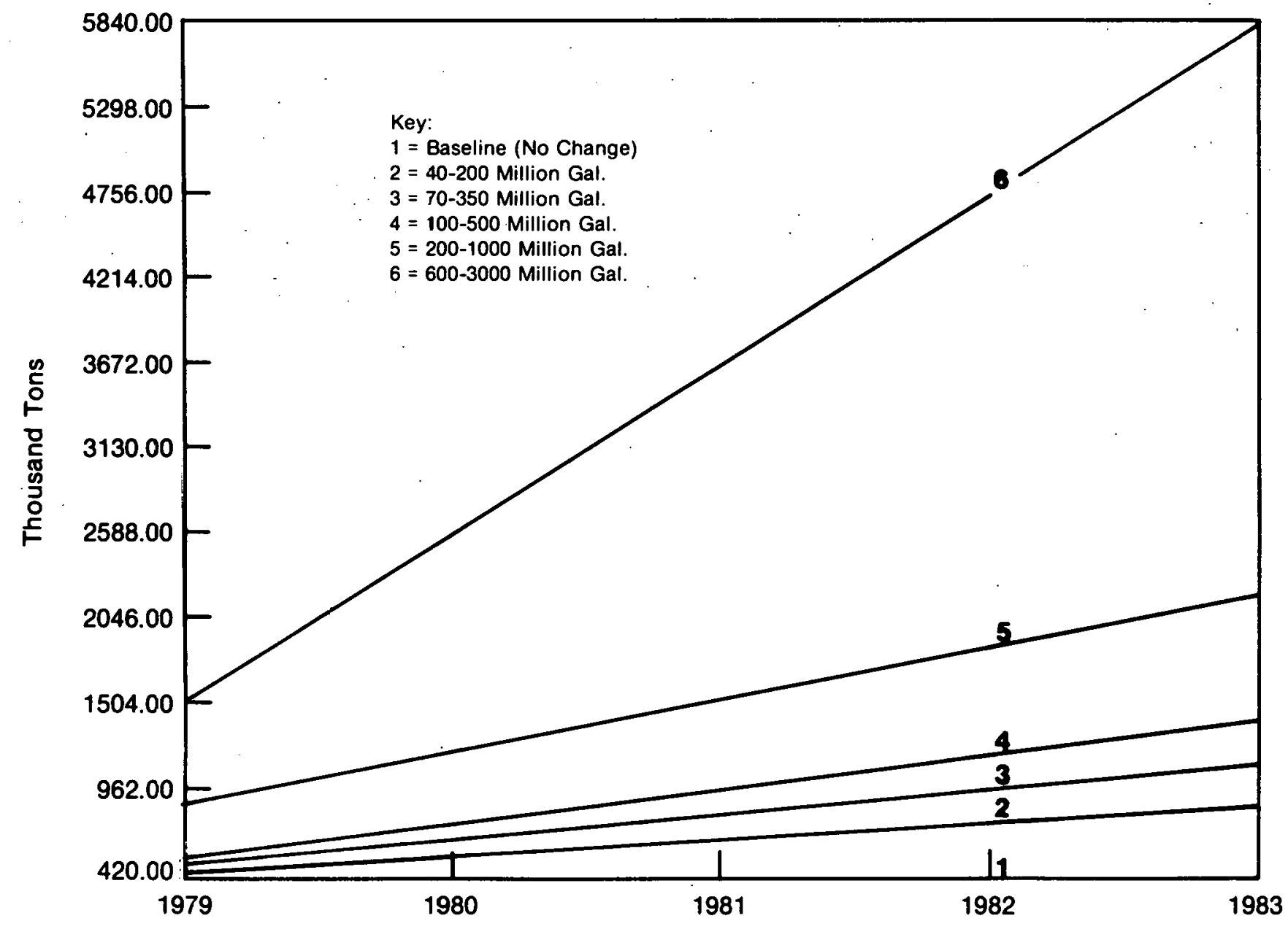

Figure 4-2. Dried Distillers' Grains Fed 


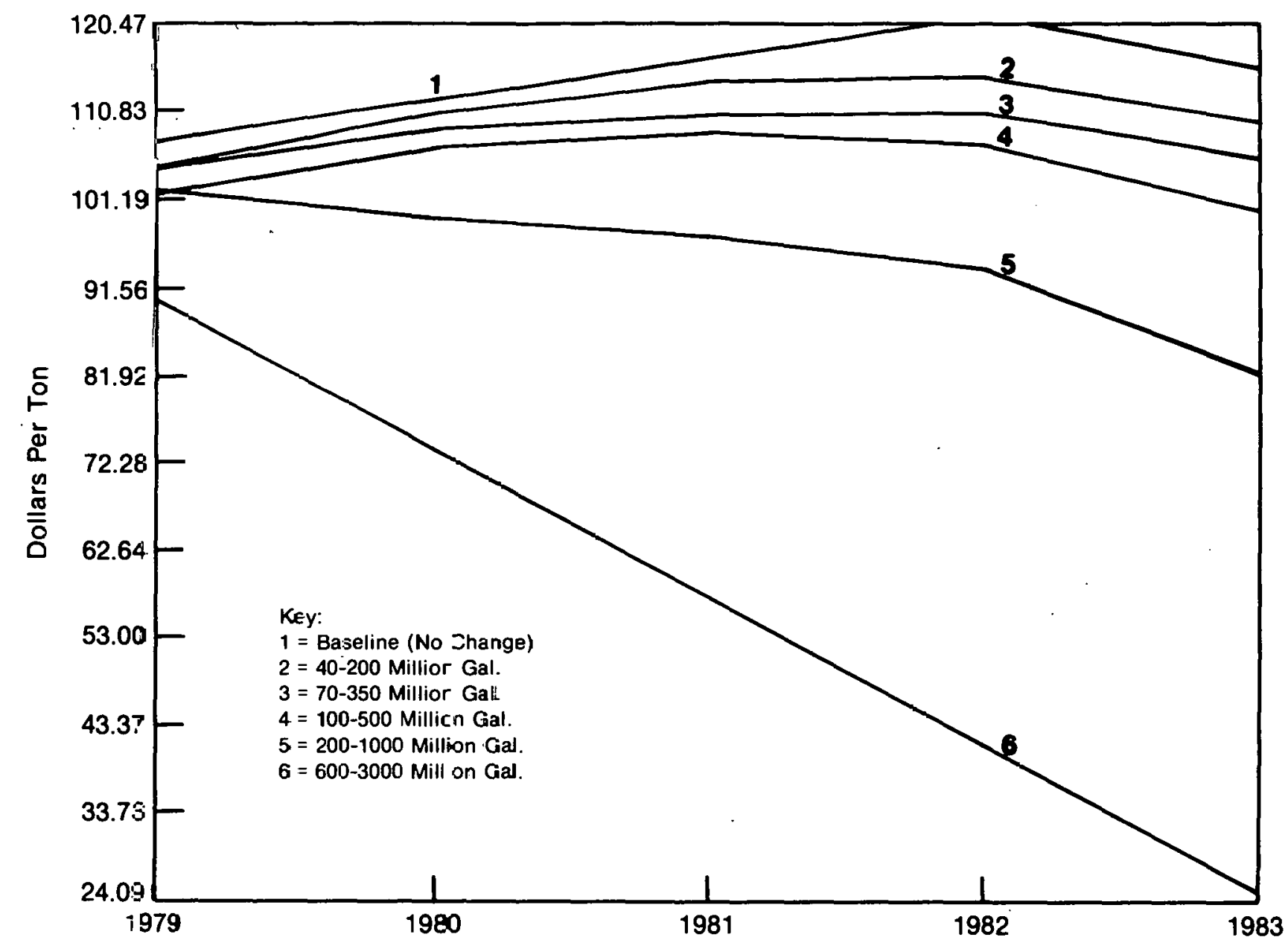

Figure 4-3. Corn Gluten Meal Price 


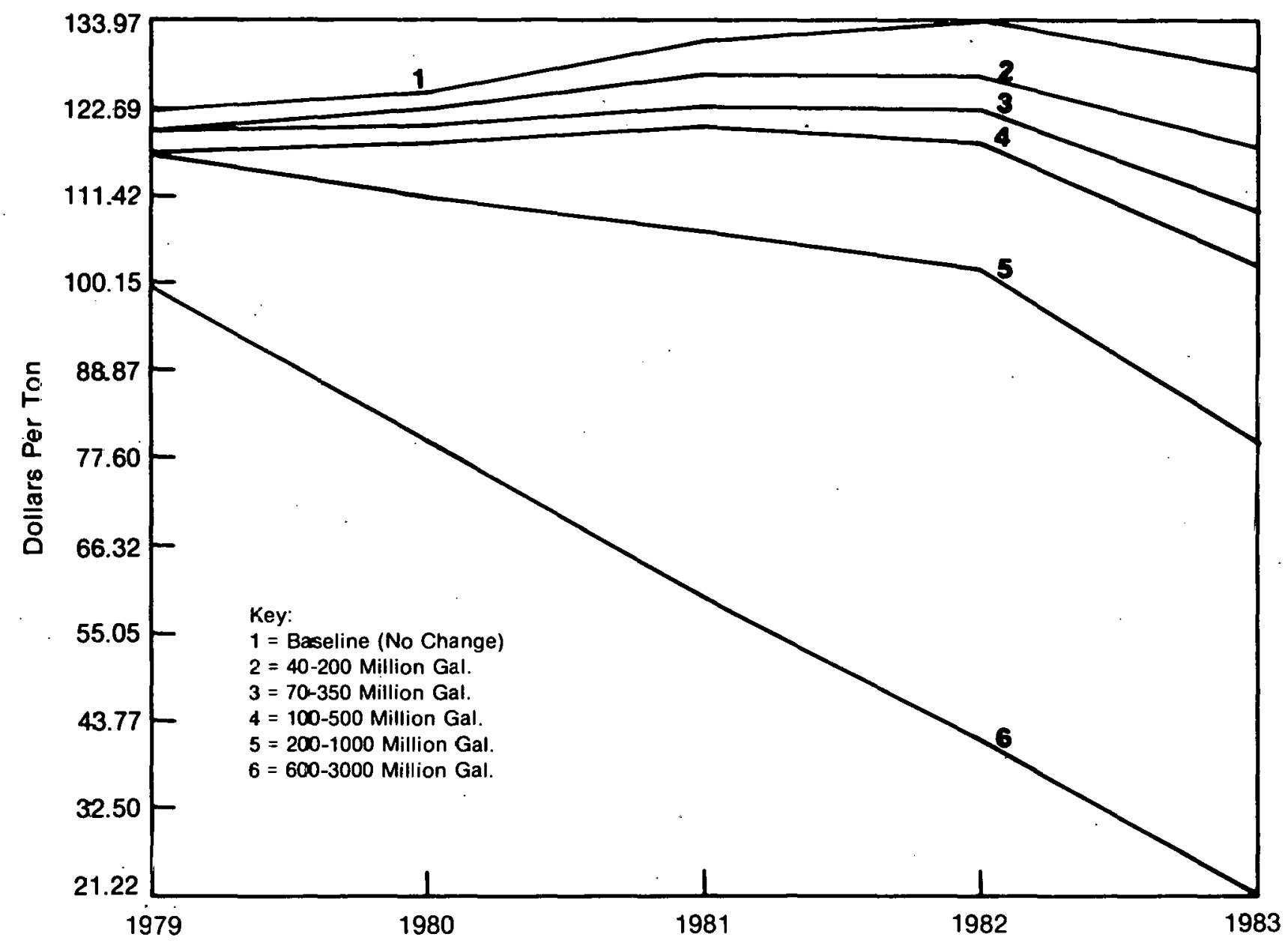

Figure 4-4. Dried Distillers' Grains Price 


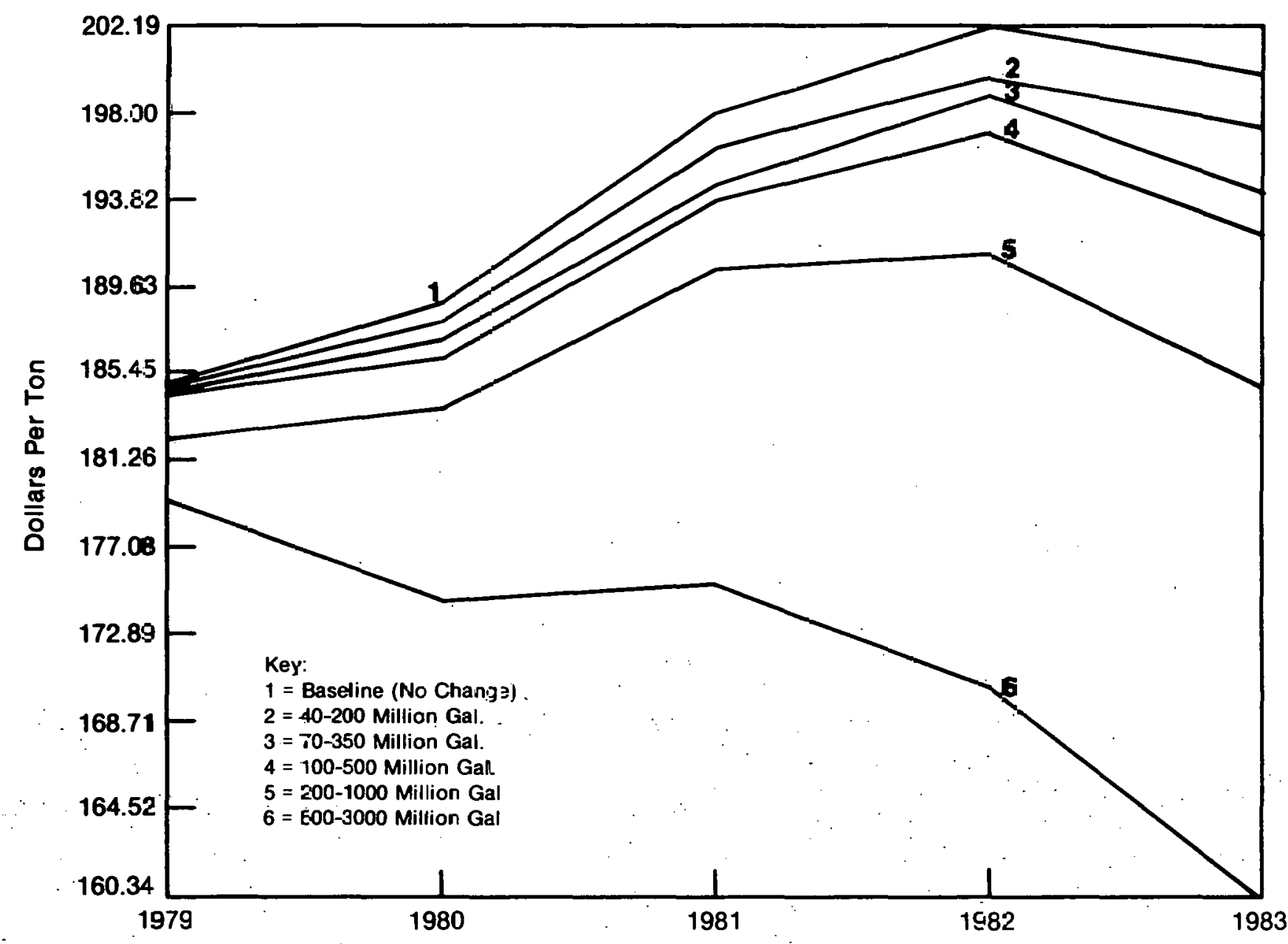

Figure 4-5. Soybean Meal Price 


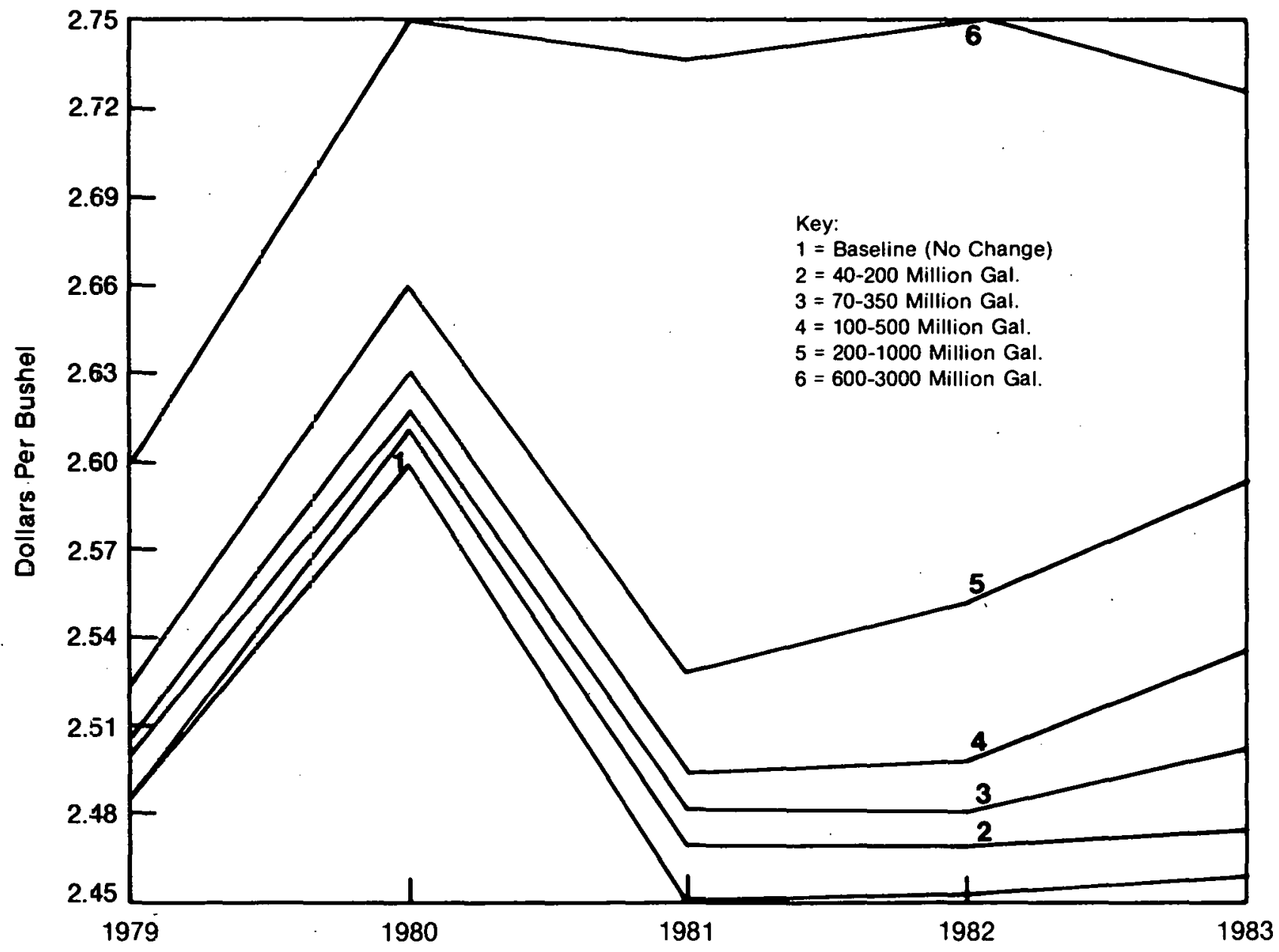

Figure 4-6. Corn Price 


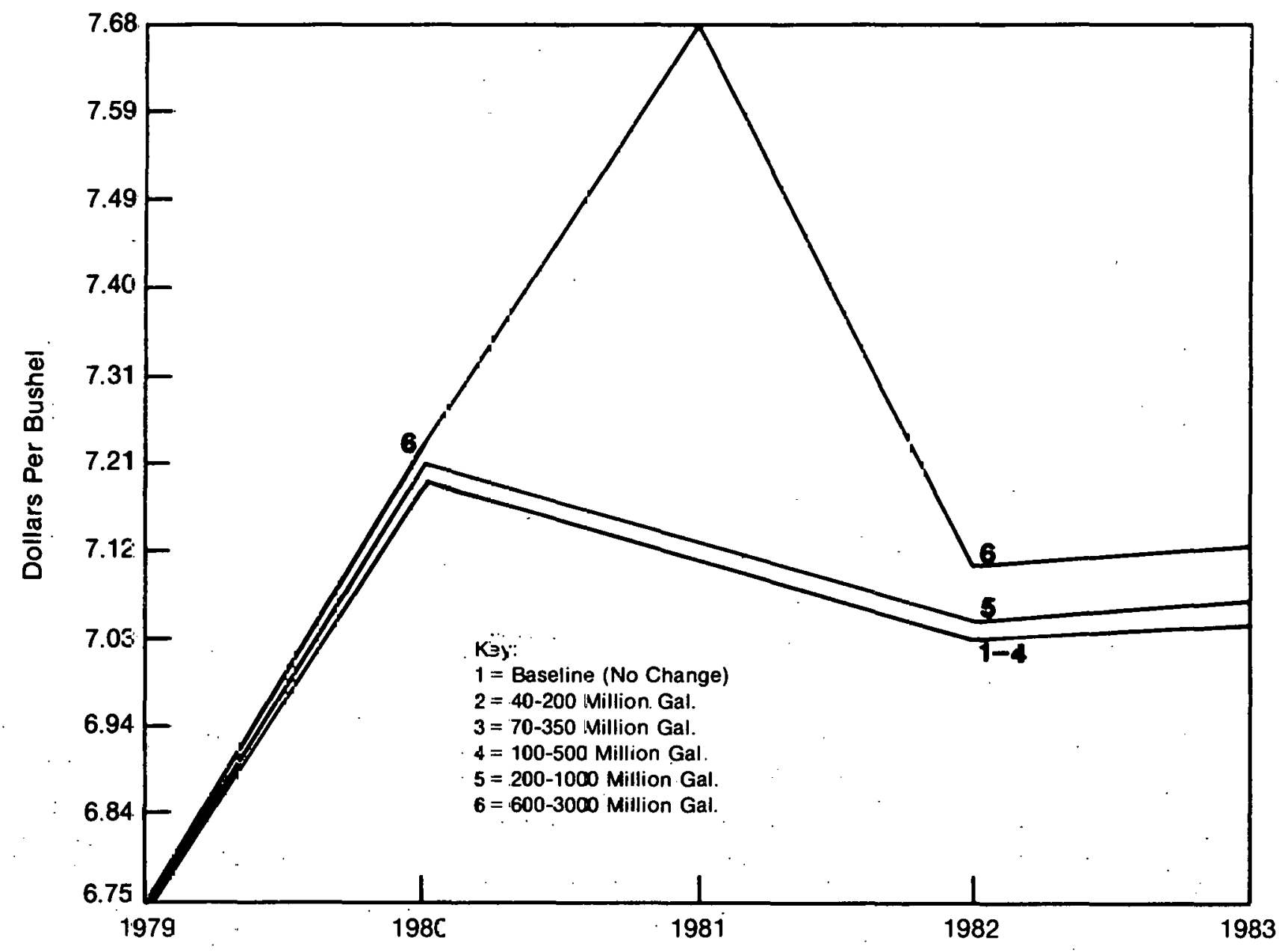

Figure 4-7. Soybean Price 


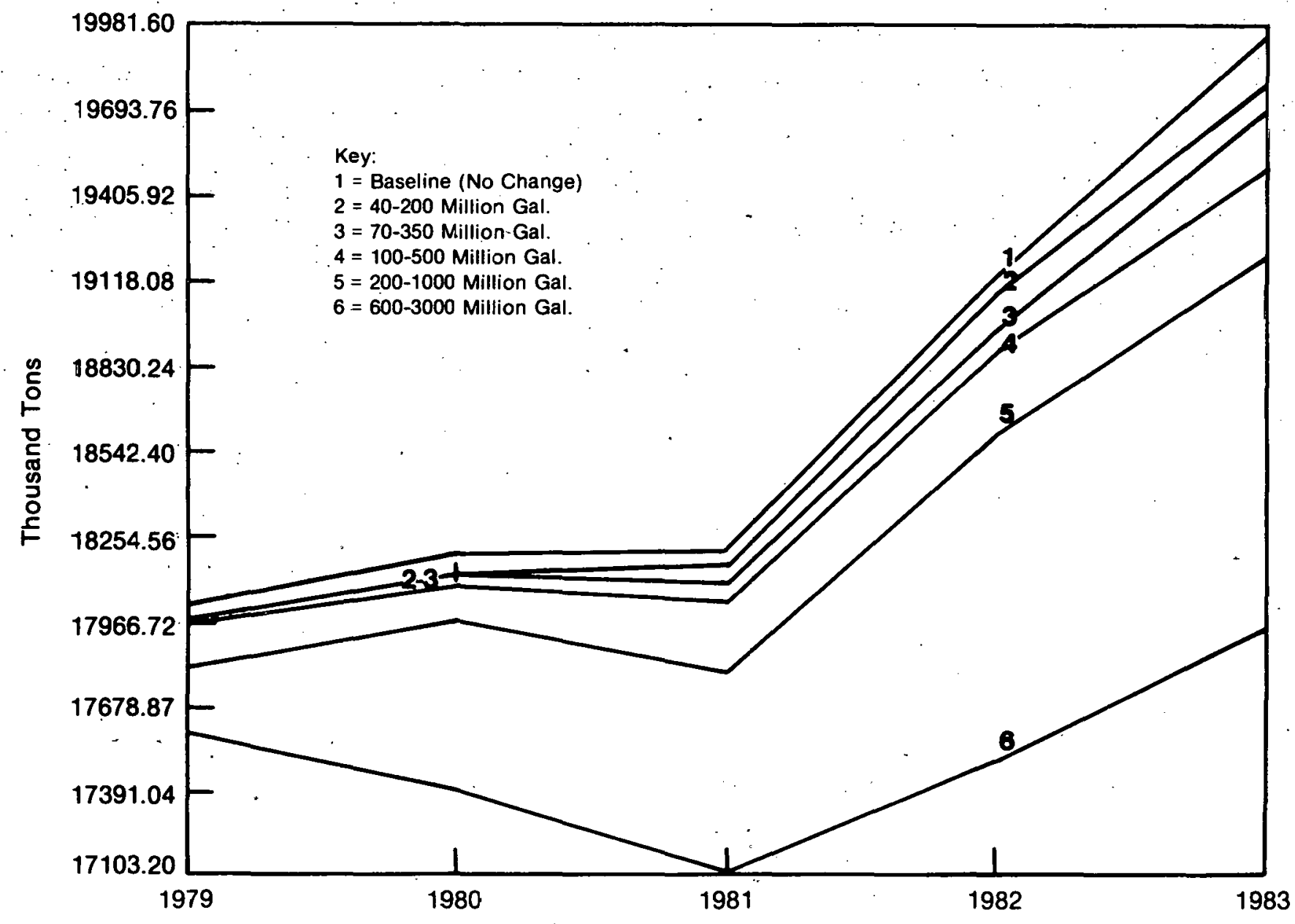

Figure 4-8. Soybean Meal Fed 


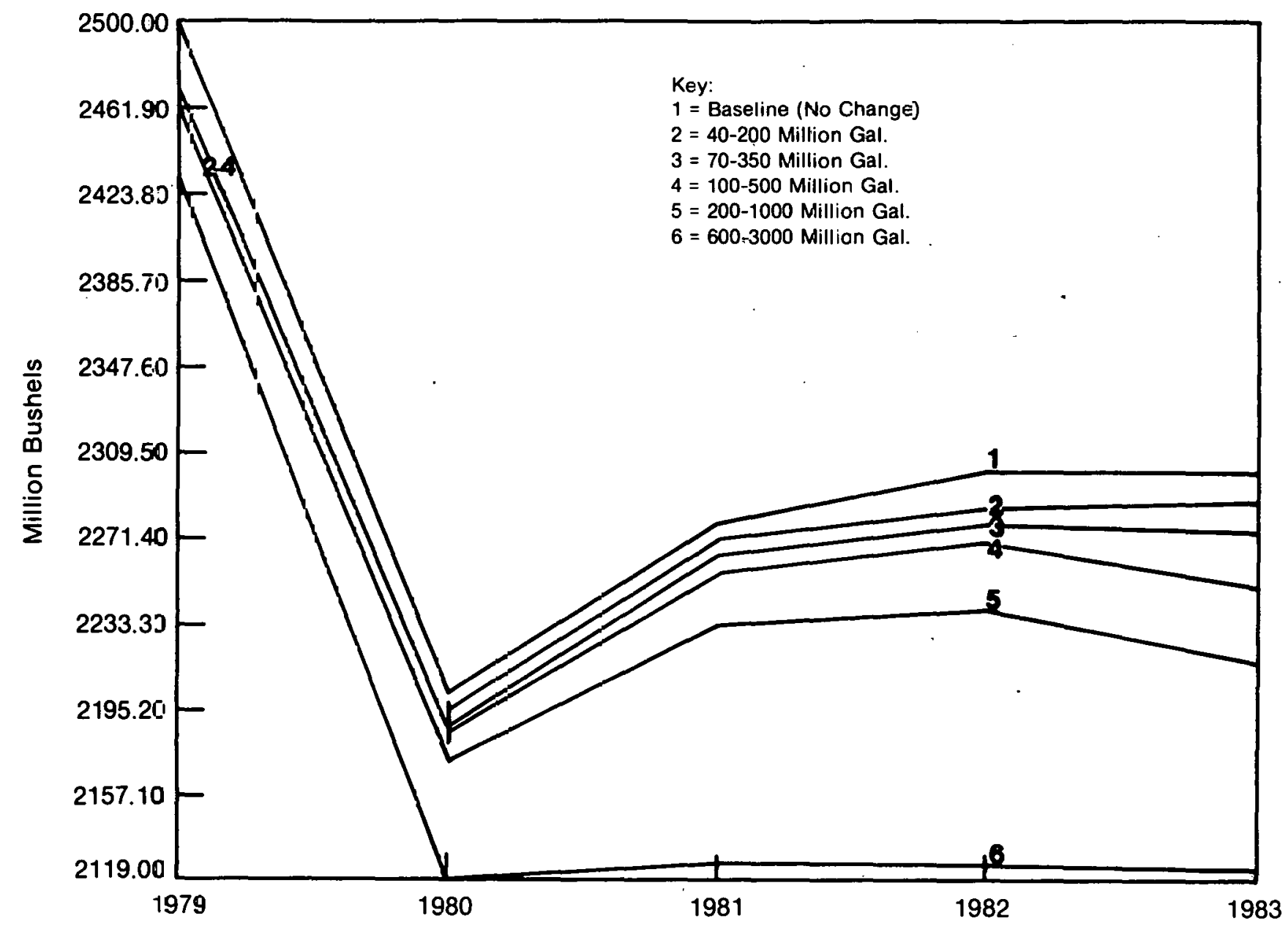

Figure 4-9. Corn Exports 


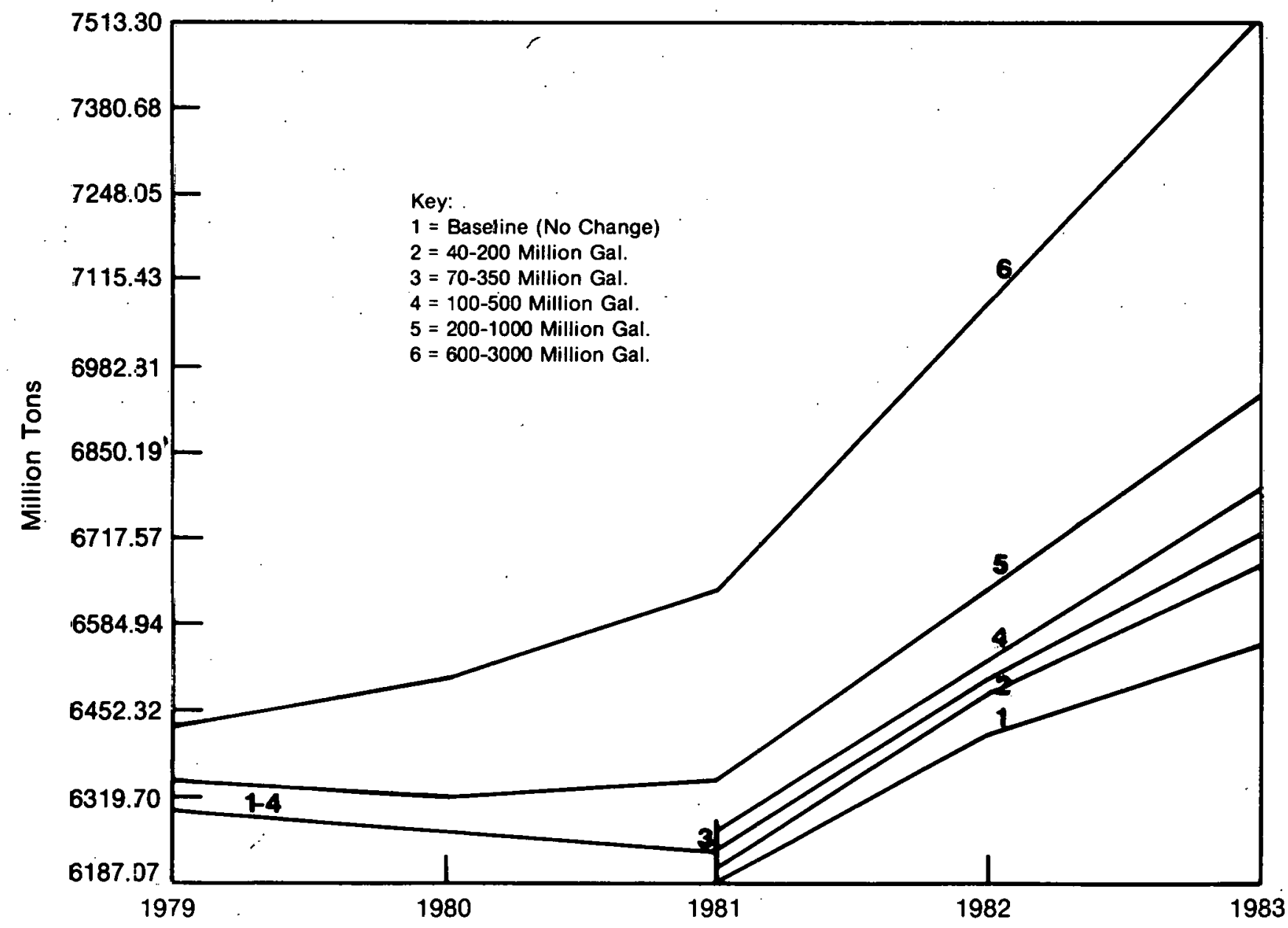

Figure 4-10. Soybean Meal Exports 


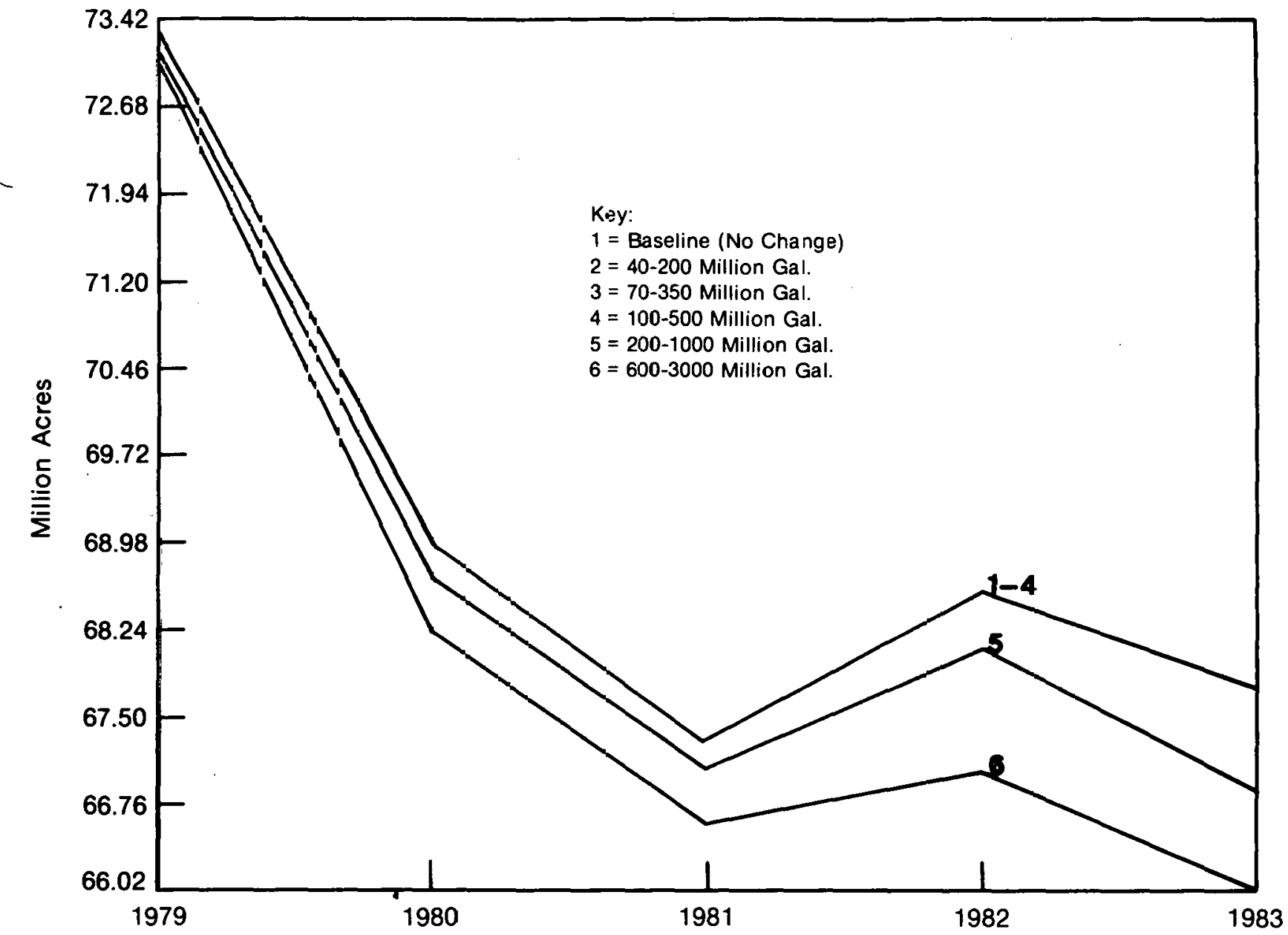

Figure 4-11. Soybean Harvested Acreage 


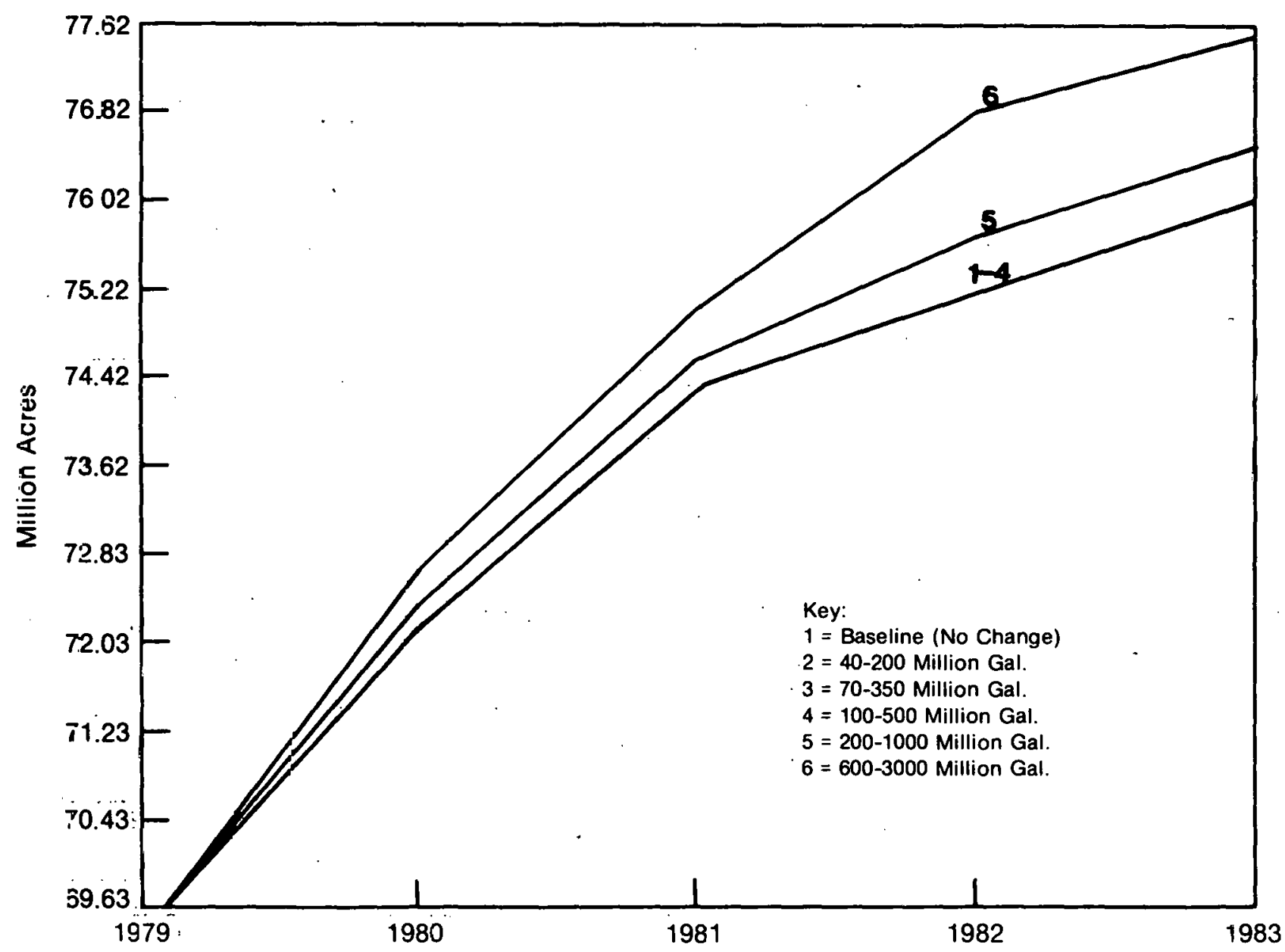

Figure 4-12. Corn Harvested Acres 


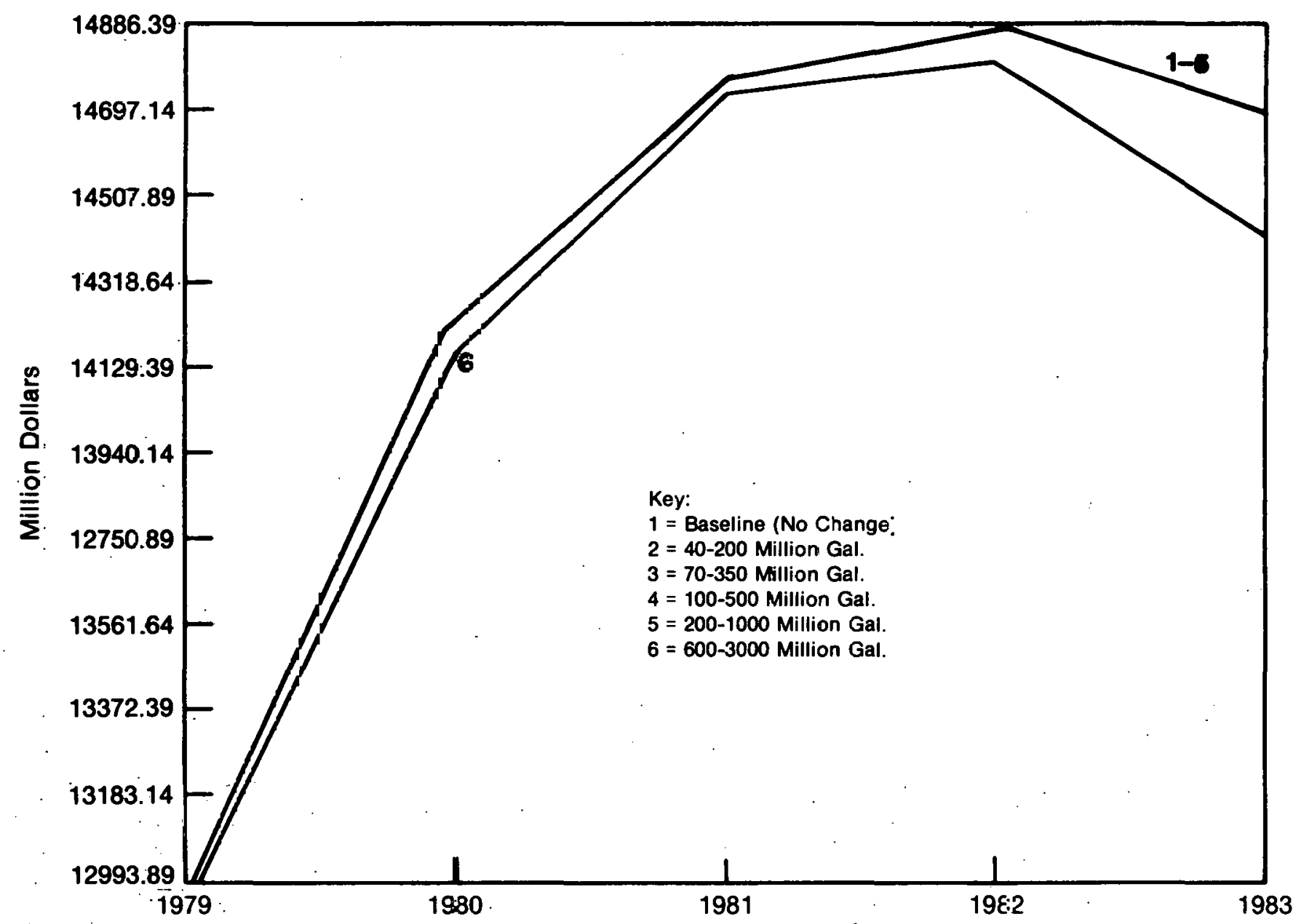

Figure 4-13. Soybean Cash Receipts 


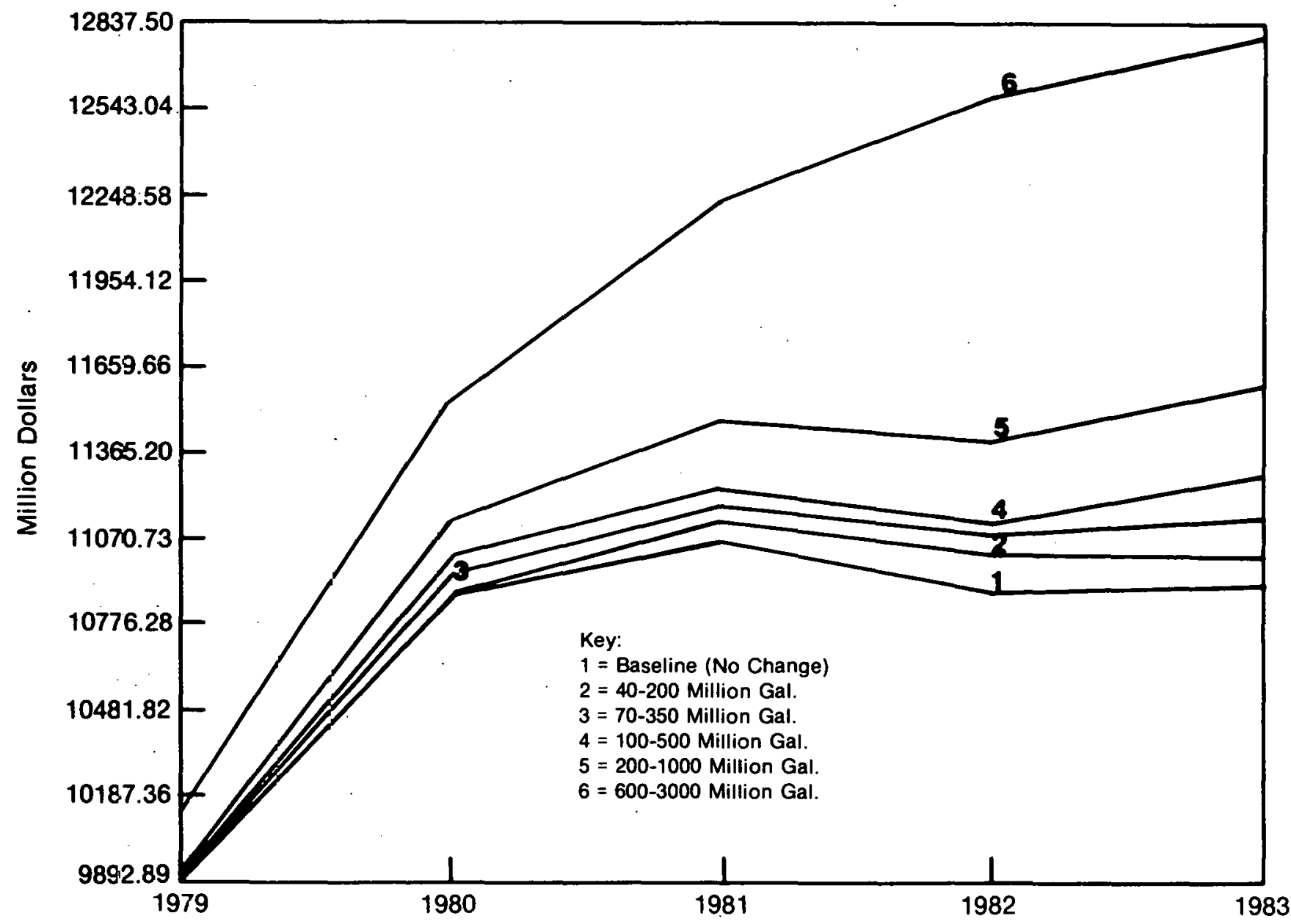

Figure 4-14. Corn Cash Receipts 


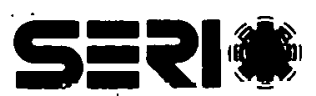




\section{SECTION 5.0}

\section{CONCLUSLONS}

\subsection{SUMMARY OF RESULTS}

The analysis and results presented in this report attempt to address in detail the critical issues surrounding the economic feasibility of obtaining motor fuels from grains. Properly applied economic methodology could lead to answers that differ significantly from conventional wisdom with respect to agricultural sector impacts and to the economic desirability of making alcohol fuels. This work focuses on the short run-up to five years-because of the short-run nature of the POLYSIM model itself. In addition, longer time periods are subject to structural changes within the agricultural sector that would vitiate much of the value of an elasticity model.

The major conclusion of this study is that the amount of alcohol that can be produced from grains over the next five years is not sufficient to cause serious upsets in the agricultural sector or to food prices. The binding constraint on alcohol production will be distillation capacity, not feedstocks. In general, the deflationary effects of joint feed products outweigh the inflationary effects on corn and wheat prices of high levels of alcohol production. From a logical perspective, this result is unremarkable and unsurprising. Any increase in the processing of a commodity that permits the least valuable portion of the commodity (the starch) to be converted to a useful product (such as fuel) while leaving the other portions of the commodity in a more useful form than they were previously, must increase the value of that commodity relative to others. The net result of this is an increase in the rate of growth of income in agriculture from near stagnation to something less than the rate of growth trend of the economy as a whole. From the standpoint of income distribution, alcohol production will encourage a production shift that will slow the relative erosion of agriculture's share of the national product.

Secondary results of our study include the following:

- The cost of providing high-protein products to livestock will fall This could mitigate the inflationary impacts on meat prices of increased corn costs and the rebuilding of depleted herds.

- The agricultural sector in the United States is sufficiently flexible to absorb large production requirem ents for fuels and chemicals to be produced jointly with food.

- Policies that encourage the growth of energy crops in marginal lands should be scrutinized carefully. Study results indicate that maintenance of the flexibility inherent in current agricultural practices can result in the provision of large amounts of energy to the economy.

- Marginal gasoline is the true competitor of fermentation ethanol. The use of average cost pricing of gasoline has obscured such viable alternatives as alcohol fuels.

- The release of lands currently in agricultural set-asides will not be necessary to promote greater production of grain. The current state of demand is sufficient to entirely eliminate that program over the next two years. 
- Mild crop disturbances here and abroad should not affect the feasibility of ethanol production in the near future. The extent to which the production of ethanol would adversely affect either wheat or com supplies is almost negligible.

- Carryover stocks of corn and soybeans are reduced under alcohol production scenarios. This will increase the impact of violent disturbances in the agricultural sector.

- Inefficient fermentation technology and low prices for joint products will make ethanol from grain costly, even relative to marginal gasoline.

- As greater production of alcohol leads to increases in corn prices relative to joint-product prices, the cost of alcohol will rise more quickly than that of corn.

\subsection{LIMTATIONS}

There are several important limitations in this study, which readers or those who wish to draw policy conclusions from these results should note. With respect to the analysis that preceded the modifications of the POLYSIM model, the omission of the vegetable oils markets represents a potential distortion of the impacts of growing additional corn. In particular, mills' demand for soybeans can be expected to decline if there are an additional 400-plus million $\mathrm{lb}$ of oil as a joint product of fermentation. This could be expected to exert further downward pressure on soybean prices and, consequently, on the desi rability of soybeans as a crop.

The production increments will most likely be exponential. There are several implications here for the results of the model. First, more volatility can be expected as the growth curve for ethanol production enters its vertical portion. Second, large-scale programs could possibly exert sufficient pressure on some parts of the agricultural sector to change the elasticity figures that form the basis of the POLYSIM model.

Again, POLYSIM is a short-run model, and thus more accurate in its output than some others. Unfortunately, many interesting policy questions have longer time horizons than are covered in this analysis. At this stage of the modeling effort, however, it is not a serious limitation. Accurate, short-term results are preferred to courageous but useless long-term projections.

Many of the important questions about ethanol production are regional. These are not addressed here. The problem of building an interregional model that is both accurate at the regional level and plausible at the national level involves types of behavior presumed by the modeler. This study does not assume optimizing behavior for the economy as a whole. Regional modeling is difficult, then, since the finer the resolution of the model, the more reasonable optimizing assumptions become.

The lack of regional resolution may blind us to important production shifts that may permit greater levels of overall production of biomass for both food and energy. One of the more obvious cases of this is the rapid increase in sunflower production in the Northern Plains. This crop will augment both protein and oil supplies to a great degree, and might make the use of other lands for sugar crop production more feasible than is now the case. Unfortunately, it is difficult to project a regional phenom ena in a national model. 


\section{SECTION 6.0}

\section{REPERENCES}

Am erican Petroleum Institute. Basic Petroleum Data Book. Washington, D.C.: API.

Annual Survey of Manufacturers. 1976. Fuels and Electric Energy Consumed. Washington, D.C.: U.S. Departm ent of Commerce, Bureau of the Census.

Buchele, W. F.; Marley, S. J. 1978. "Energy Production from Crop Residue." Proceedings of the Soil Conservation Society of America Meetings. Denver, CO: August.

Chambers, R.S.; Herendeen, R.A.; Joyce, J.J.; Penner, P.S. 1979. "Gasohol: Does it or Doesn't it Produce Positive Net Energy?" Science. Vol. 206, November 16; pp. 789- 795 .

Chemapec, Inc. 1978. "Industrial Alcohol by Continuous Fermentation and Vacuum Distillation with Low Energy Consumption." Woodbury, NY.

Chemical Week. Jan. 31, 1979.

The Conference Board. 1974. Energy Consumption in Manufacturing. Cambridge, MA: Ballinger; pp. 301-320.

Dvoskin, D.; Heady, E.O. 1977. "Economic and Environmental Impacts of the Energy Crisis on Agricultural Production." In William Lockeretz, ed., Agriculture and Energy. New York, NY: Academic Press.

Energy Daily. 1978. Vol. 6, no. 178; September 14.

Energy Daily. 1978. Vol. 6, no. 180; September 18.

Farthing, D. C.; Kliebenstein, J. B. 1979. "Impacts of Fuel Pricing and Nonprice Allocation Scenarios on High and Low Risk Crop Producers." Meetings of the American Agricultural Economics Association. Pullman, WA: July 29-A ugust 1.

Ferguson, C. E. 1969. The Neoclassical Theory of Production and Distribution. Cambridge, U.K.: The University Press.

Flaim, S. J.; Mount, T. D. 1978. Federal Income Taxation of the United States Petroleum Industry and the Depletion of Domestic Reserves. Golden, CO: Solar Energy Research Institute; Report No. TR-52-041.

Forster, D. L.; Rask, N. 1977. "Changes in Fertilizer Usage and Crop Production Under Scarce Energy Supplies." In William Lockeretz, ed., Agriculture and Energy. New York, NY: Academic Press.

Fuss, M.; McFadden, D. 1978. Production Economics: A Dual Approach to Theory and Applications. Amsterdam: Nortlı Hülland.

Hertzmark, N., I. 1979. A Proposition on Energy Analysis and Economic Efficiency. Golden, CO: Solar Energy Research Institute; Report No. TR-51-332.

Hertzmark, D. I.; Gould, B. 1979. The Market for Ethanol Feed Joint Products. Golden, CO: Solar Energy Research Institute; Report No. RR-51-357.

International Petroleum Finance. 1979. Vol. 2, No. 19; October 8.

Kal ter, R. J.; Vogely, W. A., eds. 1976. Energy Supply and Government Policy. Ithaca, NY: Cornell University Press. 
Litterman, M.; Eidman, V.; Jensen, H. 1978. Economics of Gasohol. University of Minnesota: Department of Agricultural and Applied Economics, Economic Report ER 78-10; December.

Mensah, E. K.; Miranowski, J. A. 1979. "Derived Demand for Energy in Agriculture: Eff ects of Price, Substitution, and Technology." Meetings of the American Agricultural Economics Association; Pullman, WA: July 29-August 1.

Office of Technology Assessment. 1979. Gasohol: A Technical Memorandum. Washington, D.C.: OTA; September.

Oil and Gas Journal. 1979. Vol. 77, No. 28; July 9; p. 4.

Oil and Gas Joumal. 1979. Vol. 77, No. 42; Octọber 14; p. 219.

Pimentel, D.; Dritchilo, W.; Krummel, J.; Kutzman, .T. 1975. "Enorgy and Land Con straints in Food Production." Science. Vol. 190; November 21; pp. 754-76 l.

Rask, N.; Forster, D. L. 1977. "Corn Tillage Systems-Will Energy Costs Determine the Choice?" In William Lockeretz, ed., Agricul ture and Energy. Ncw York, NY: Acade mic Press.

Scheller, W. A.; Mohr, B. J. 1977. "Gasoline Does, Too, Mix with Alcohol." Chemtech. October; pp. 616-23.

Sladek, T. A. 1978. "Ethanol Motor Fuels and Gasohol." Mineral Industries Bulletin. Golden, CO: Colorado School of Mines; May.

Tyner, W. E.; Bottum, J. C. 1979. Agricultural Energy Production Economic and Policy Issues. West Lafayette, $\mathbb{N}$ : Department of Agricultural Economics, Purdue University. Station Bulletin No. 240; September.

U.S. Department of Agriculture. 1979. Agricultural Statistics-1978. Washington, D.C.: U.S. Governm ent Printing Office.

U.S. Department of Energy. 1979. The Report of the Aleohol Fuels Poligy Review. DOE/PE-0012; June.

Weisz, P. B.; Marshall, J. F. 1979. "High-Grade Fuels from Biomass Farming: Potentials and Constraints." Science. Vol. 206; October 5; pp. 24-29. 


\section{APPENDIX}

\section{ENERGY ANALYSIS}

The issue of whether alcohol fuel does or does not produce net energy output has been an important one in previous analyses of the feasibility of using alcohol fuels (U.S. DOE 1979; Chambers et al. 1979). The two analyses cited will not be replicated here. It is clear from their results that conventional distillation technology, using feedstocks derived from energy-intensive agriculture, at best will be only slightly positive and more likely will be negative. Small changes in assumptions about whether the stillage is to be included as an output or a negative input, what type of cultivation practices are used, and the fate of the straw or stover are sufficient to draw the energy balance from positive to negative or vice versa. In one sense, the entire debate is otiose since any refined energy product, from gasoline to electricity, will turn out to have a negative balance when computed on the basis of outputs divided by inputs. In fact, any fuel possessing a ratio in excess of unity would have fair claim to be a perpetual motion machine of the first type.*

As an alternative to this debate, we need to concentrate on three different aspects of the energy balance question. The first one is the most obvious: al ternatives to conventional distillation technologies. The second is the question of the quality of the energy used in various stages of processing and growing. The third is a more comprehensive view of the energy requirements of alternative ways of producing all of the potential outputs of a biomass energy refinery producing both food/feed and energy outputs.

One of the better known alternatives to conventional distillation technology is vacuum distillation. This process is used by the Chemapec Company, a Swiss Architecture and Engineering (A\&E) firm. Two aspects of the process are of interest. The first is the preseparation of corn into starch, oil, and feed. The cellulose fraction is removed later and is anaerobically digested to provide some of the process energy. The external energy requirements of the process appear to be about 30,000 Btus per gallon of ethanol prodyced (Chemapec 1978). The cellulose fraction of the grain is used to provide about $.4 \mathrm{~m}^{3}$ of methane $\left(10 \mathrm{ft}^{3}\right)$ per bushel of corn processed. This provides a substantial fraction of the total process energy required since the vacuum distillation process is less encrgy-intensive to begin with. The second interesting feature is that there appears to be a clear process distinction between beverage alcohol and power alcohol. The specification sheet for the two processes indicates that considerably fewer contaminants are found in the beverage alcohol. Allowing such contaminants as esters, aldehydes, methanol, and fusel oils to remain in the alcohol should result in lower production costs for this alcohol compared with one that is distilled to beverage standards regardless of its ultimate disposition.

*Pauli $(1973$; p.7) defines a perpetual motion machine of the first type as one that can produce heat energy from nothing. The first law of thermodynamics states, inter alia, that during a cycling process heat can be transformed only into work or vice versa. The second law states that this cycling process is finite since each transformation causes entropy (unavallable work) to increase. 
On a straight energy in/energy out basis, there is no refined energy product that can claim to have an energy efficiency ratio greater than unity.* The most obvious reason for this is that the energy value of the feedstock must al ways be greater than the energy content of the refined product, in the case of fuels. The important question here, then, must center on the quality of the products that are produced with given feedstocks and auxiliary inputs. An alcohol distillery fueled by coal may indeed have a poor energy balance if we really believe that scores of more than one are possible in our energy balance ratings. However, we must inquire as to the potentials for coal to produce a premium liquid fuel or some other type of transportation fuel in order for the comparison with other alternatives to be proper. Recent reports on the thermal efficiency of the South African synthetic fuel plant indicate that the energy out/energy in ratio is on the order of 0.35 for an output that consists mostly of light fractions of synthetic crude oil suitable for refining to gasoline. The work of Chambers et al. (1979) indicates that the net energy loss will never drop as low as the figure for fossil synthetic fuels or for electricity (p. 793). Since we apparently have no qualms about the production of electricity or fossil synthetic fuels, at least on the basis of net energy, then the policy basis of the entire discussion appears to be nonexistent. An earlier paper shows that the stress on simple Btu accounting is often misleading in terms of results and can serve to misdirect the proper debate on energy efficiency (Hertzmark 1979). A more sound basis for the argument is to consider the thermodynamic efficiency of alternative production schemes.

Most of the process energy required for the fermentation of grain and the distillation of mash to pure alcohol is relatively low-temperature heat or steam. Presently, well organized markets do not exist for low-grade energy. It is understandable, therefore, that little attention has been paid to the possibilities of using either the thermal effluent from electric power generation or that from chemical process factories as major heat sources for the production of fuel alcohol. Counting the Btus in and out of a plant that makes use of its "waste" heat is not necessary if the al ternative use of this heat is simply to become additional thermal effluent. The importance of properly using the entire heat potential of energy resources is reflected in debates about various externalities nf energy use, such as heat, $\mathrm{CO}_{2}$, sulphur, etc. Some people in the field are now properly sensitized to effluents other than the thermal kind and consider limitations on these effluents to be policy objectives. Thermal effluents are a resource valuable in lowtemperature applications and otherwise a nuisance. Of course, once the concept of thermodynamic matching of sources and uses of energy is taken more seriously, there may be some competition for these thermal effluents.** At present we may conclude that this energy source is available at approximately zero cost; *** the energy balance is moot and minor.

The final aspect of energy analysis that deserves attention is a novel approach to the entire issue of energy analysis of alcohol fuels. As shown previously (Hertzmark and Gould 1979), the diversion of corn grain to ethanol and joint products leads to a series of indirect substitutions in the livestock sector of the agricultural economy. One of the most striking of these is that additional use of corn grain in the livestock sector becomes

*See Pauli, p. 7.

**A wareness of the cost savings possible by cascading energy from its highest thermodynamic grade (mechanical work) to an ambient state may well serve to induce firms to locate near to sources of "waste" or low quality heat.

***Excluding the piping and heat exchanges needed for any energy source. 
unnecessary because of substitutions of various hays for the carbohydrate portion of the grain. This suggests that one measure of efficiency in energy use would be a comparison of the energy requirements of various types for two alternative food and fuel systems. The first is simply the present system, and the second is a biomass refinery with associated forage crop production.

The two alternative production systems are shown in Sec. 4.0 (Table 4-1). The first is a conventional corn production system with an additional 2 gallons of gasoline to provide a fuel production equivalence with the alternative biomass refinery system. Using results from the previous study of the uses for the feed joint products, calculations show that at a 10\% dietary penetration of distillers' grains, there would be an increase of about $1: 1$ in the consumption of such other feeds as alfalfa hay. This means that for each reduction in the quantity of corn grain that is fed into the ration, there will be an almost matching increase in the quantity of forages that are fed to the livestock. Also, process energy is required to preseparate the grain and to distill the alcohol. There is no need to account for the energy value of the corn grain itself since this is simply one form of stored solar energy. For the two systems producing identical food and fuel outputs, the biomass refinery system will be more efficient in its use of fuel if modern technologies are used in the processing stage. Additionally, the use of beverage alcohol technology does not appear wise from an energy standpoint. These figures are conservative in that there was no processing energy assumed in the conventional system.* In addition, we used the energy requirements for producing gasoline from high grade petroleum rather than from marginal deposits or from syncrude.** For the use of modern distillation technology, the

*A more complete comparison would presume dry milling of corn in the conventional system also. One of the major economic outputs of the biomass refinery is corn oil. The conventional system does not produce the same economic value, al though it has the same calorie value as the biomass refinery.

**A Analytically, the indirect substitution argument is easily shown. Let y be a vector of energy sources, $r$ a vector of costs, $M$ a matrix of input coefficients, and $Z$ a vector of output requirements. The resource constraints are represented by the inequality $\mathrm{y} \leq \gamma$. To minimize the overall cost of production we solve

$$
\begin{array}{cl}
\text { Min } & \mathbf{r}^{\prime} \mathrm{y} \\
\mathrm{y} & \\
\text { s.t. } & \mathrm{M}^{\prime} \mathrm{y} \leq \mathrm{Z}, \\
& \mathrm{y} \leq \mathrm{Y} \\
& \mathrm{Y} \geq 0(\mathrm{i}=1,2, \ldots, \eta) .
\end{array}
$$

A change in relative costs will change the components of the vector $r$. Suppose that the matrix $M$ shows more than one way to produce several of the outputs $Z_{j}$. In particular, suppose that $Z_{1}$ is electricity, $Z_{2}$ gasoline, and $Z_{3}$ high pressure steam. Now suppose that $\mathrm{Y}_{1}$ (solar) substitutes for $\mathrm{Y}_{2}$ (petroleum) in producing $\mathrm{Z}_{2}$ due to an increase in $\mathrm{r}_{2} / \mathrm{r}_{1}$. Assume that $r_{2}$ increases relative to $r_{3}$ (coal price). This incudes an additional substitution in $Z_{1}$ of coal for oil. Now, however, additional coal demand in $Z_{1}$ causes $r_{3}$ to rise relative to $r_{1}$. This induces penetration of both $Y_{1}$ and $Y_{2}$ in $Z_{3}$. This is a simple explanation for a complex dynamic process. In a dynamic model, analogous results could be obtained provided that the appropriate elasticities of substitution are greater than unity. The royalty terms for the two exhaustible resources serve to limit the supply elasticity for both coal and oil. One approach that is useful here is the recursive approach of Day (1973). After each solution, a recursion equation would modify $r$ of $M$ according to resource exhaustion criteria or technological change criteria. The series of solutions generates a time path for the choice variables $\mathrm{Y}$ and solution values. 
implications of this exercise are clear: there will be an unambiguous reduction in the use of fossil energy for a food/fuel system that produces fuels and foods from the same biological and industrial plant. 


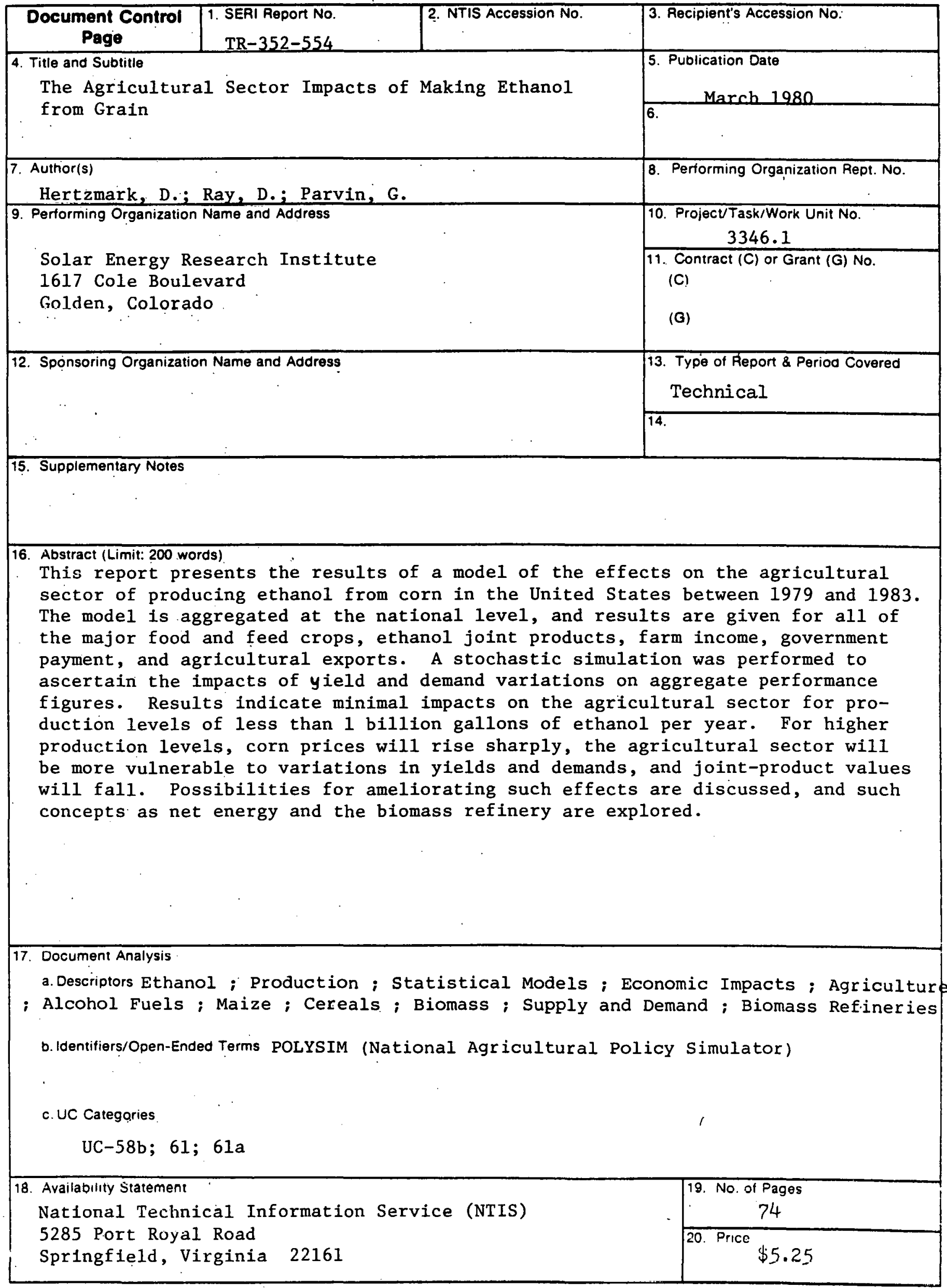

